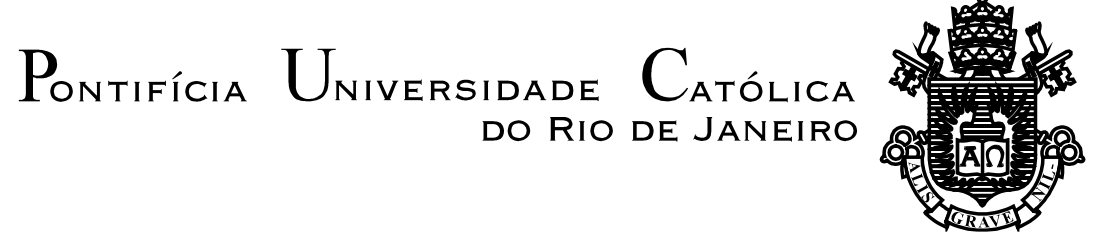

Débora dos Santos Camilo

\title{
Os blocos sessões do CORPO - O CORPO e seus blocos sensações
}

Dissertação de Mestrado

Dissertação apresentada como requisito parcial para obtenção do grau de Mestre pelo Programa de Pós-Graduação em Literatura, Cultura e Contemporaneidade do Departamento de Letras do Centro de Teologia e Ciências Humanas da PUC-Rio.

Orientador: Prof. Frederico Oliveira Coelho Coorientador: Prof. Miguel Jost Ramos

Rio de Janeiro

Março de 2016 


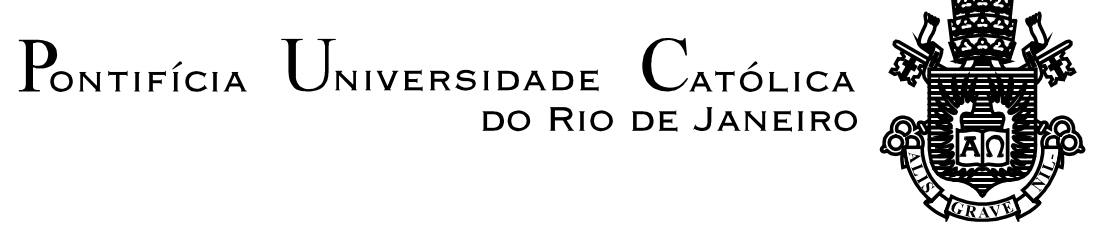

Débora dos Santos Camilo

\title{
Os blocos sessões do CORPO - O CORPO e seus blocos sensações
}

Dissertação apresentada como requisito parcial para obtenção do grau de Mestre pelo Programa de Pós-Graduação em Literatura, Cultura e Contemporaneidade do Departamento de Letras do Centro de Teologia e Ciências Humanas da PUC-Rio. Aprovada pela Comissão Examinadora abaixo assinada.

\author{
Prof. Frederico Oliveira Coelho \\ Orientador \\ Departamento de Letras - PUC-Rio
}

Prof. Miguel Jost Ramos

Coorientador

Bolsista Pós-Doutorado PUC-Rio/PNPD

Prof. Julio Cesar Valladão Diniz

Departamento de Letras - PUC-Rio

Profa. Ana Cristina de Rezende Chiara

UERJ

Profa. Denise Berruezo Portinari Coordenadora Setorial do Centro de Teologia e Ciências Humanas - PUC-Rio

Rio de Janeiro, 21 de março de 2016 
Todos os direitos reservados. É proibida a reprodução total ou parcial do trabalho sem autorização da universidade, da autora e do orientador.

Débora dos Santos Camilo

Graduou-se em Letras pela Universidade Castelo Branco. Cursou Literatura, Arte e Pensamento Contemporâneo na PUC-Rio.

Ficha Catalográfica

Camilo, Débora dos Santos

Os blocos sessões do corpo : o corpo e seus blocos sensações / Débora dos Santos Camilo ; orientador: Frederico Oliveira Coelho ; coorientador: Miguel Jost Ramos. - 2016.

109f. : il. color. ; $30 \mathrm{~cm}$

1. Dissertação (mestrado) - Pontifícia Universidade Católica do Rio de Janeiro, Departamento de Letras, 2016.

Inclui bibliografia.

1. Letras - Teses. 2. Sexualidade. 3. Corpo. 4. Refazimento. 5. Dispositivo. 6. Erotismo. I. Coelho, Frederico Oliveira. II. Ramos, Miguel Jost. III. Pontifícia Universidade Católica do Rio de Janeiro. Departamento de Letras. IV. Título

CDD: 800 


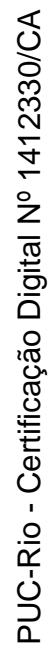

À Renata, Gabriel e Laura 


\section{Agradecimentos}

Ao meu coorientador Miguel Jost por acreditar.

Ao Capes e à PUC, pelos auxílios concedidos, sem os quais este trabalho não poderia ter sido realizado.

A Cláudia Chigres por entender o meu caos.

Ana Kiffer e Fred Coelho, vocês são inspirações nesse caminhar.

Marília, obrigada por entender o início das minhas desordens e, sobretudo, por trazer um frescor, um sopro de luz nos momentos mais difíceis.

Júlio Diniz, o seu sim mudou TUDO.

Ana Chiara, obrigada por participar da etapa final deste processo. Além disso, obrigada pela participação tão ativa na defesa com seu lindo e longo texto. 


\section{Resumo}

Camilo, Débora dos Santos; Oliveira, Frederico Coelho. Os blocos sessões do corpo - o corpo e seus blocos sensações. Rio de janeiro, 2016. 109p. Dissertação de Mestrado - Departamento de Letras, Pontifícia Universidade Católica do Rio de Janeiro

A dissertação desenvolve um debate crítico do agenciamento do corpo como produtor e receptor de impulsos eróticos. Procurou-se compreender através dos debates acerca das mudanças da cultura a evidência do corpo nas resistências e como um espaço de produção de novas subjetividades. O contexto dessa pesquisa tem como objetos: a produção de Cassandra Rios em seus romances e a linguagem plástica trabalhada nos objetos, performances e instalações de Márcia X. O modo de escrita de Hélio Oiticica é um dispositivo utilizado para aproximar as duas artistas. Dessa forma, analiso criticamente os diferentes tratamentos estéticos da força explosiva da sexualidade.

\section{Palavras-chave}

Sexualidade; corpo; refazimento; dispositivo; erotismo. 


\section{Abstract}

Camilo, Débora dos Santos; Oliveira, Frederico Coelho (Advisor). The blocks sessions body - body blocks and their sensation. Rio de Janeiro, 2016. 109p. MSc. Dissertation - Departamento de Letras, Pontifícia Universidade Católica do Rio de Janeiro

The dissertation develops a critical discussion body as mediation producer and erotic pulse receiver. It tries to realize through of discussions about the changes of the culture of evidence in resistence body, and, as a new production space subjectivities. The context of this research has as objects: Cassandra Rios' production in her novels and plastic languagecrafted the objects, performances and Device for Marcia X. The Helio Oiticica's writing man-ner is a device used to bring the two artists. Thus, I critically analyse the different aesthetic treatments of the explosive power of sexuality.

\section{Keywords}

Sexuality; body; remake; device; eroticism. 


\section{Sumário}

1 Introdução 10

2 O erotismo e suas questões 20

3 Seja Safo de Perdizes seja herói 44

$4 \quad$ Os Metaesquemas-corpos de X ou 69

4.1 A performance ou o happening? 73

4.2 Objetos e instalações 78

4.3 Outros objetos e instalações $\quad 82$

4.4 Medalhinhas $\quad 85$

$\begin{array}{lll}4.5 & \text { Touch me } & 87\end{array}$

5 Conclusão 94

6 Referências bibliográficas 101 


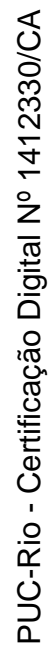

Se escolhermos, podemos viver num mundo de ilusão reconfortante. Noam Chomsky 


\section{1- Introdução}

O que nos torna felizes ou infelizes não é o que as coisas são objetiva e realmente, mas o que elas são para nós, em nossa concepção.

Arthur Schopenhauer

Os enários tarar influências, levantar uma proposta para o debate, elencar seus intercessores - os três processos que fazem parte da escrita de uma dissertação. Processos que se perdem e são recuperados ao longo de dois anos. Nessas imbricações muitas anotações são feitas, muitos post-it, marcadores de texto e afins são usados. Essa escrita constituiu-se dessa forma: idas e vindas, esgarçamento da língua, esquecimento de regras, pensamentos incompletos. Além disso, esse texto possui como proposta inicial apresentar-se como um bloco que possui anotações sobre os corpos criados por Cassandra Rios e Márcia X.

Recorro a Caio Fernando de Abreu em Morangos mofados ${ }^{1}$ : Caio escreve uma carta para seu amigo José Márcio Penido, em 1979. Encontro o que preciso:

Você quer escrever. Certo, mas você quer escrever? Ou todo mundo te cobra e você acha que tem que escrever? Sei que não é tão simplório assim, e tem mil coisas outras envolvidas nisso. Mas de repente você pode estar confuso porque fica todo mundo te cobrando, como é que é, e a sua obra? Cadê o romance, quedê a novela, quedê a peça teatral? DANEM-SE, demônios.

[...]

Ou escreva então para destruir o texto, mas alimente-se. Fartamente. Depois vomite. Pra mim, e isso pode ser muito pessoal, escrever é enfiar um dedo na garganta. Depois, claro você peneira essa gosma, amolda-a, transforma. Pode sair até uma flor. Mas o momento decisivo é o dedo na garganta.

\footnotetext{
${ }^{1}$ ABREU, C.F. Morangos mofados, p. 216 e 218.
} 
Começo o meu dedo na garganta pela dificuldade de encontrar uma pesquisa que possa aproximar da minha zona de leitura: a possibilidade de refazer o corpo através de um campo da sexualidade - o erotismo. A dificuldade de escrever sobre uma temática considerada áspera, mutilada, desagradável. De encontrar no Brasil uma pesquisa sobre essa temática. O que encontro são textos separados e pesquisadores falando, elencando questões pontuais e normalmente atreladas à forma de censura.

A proposta é pensar o refazimento do corpo via alguns conceitos. De acordo com as leituras dos estudos e propostas de Bataille, o erotismo possui um tripé: a morte, a reprodução e a violência. Além disso, o erotismo apresenta-se de três formas: dos corpos; dos corações; o sagrado.

O erotismo dos corpos “é o mais visível, pois, tem seu ápice na fusão dos corpos." "2 Já o do coração - representa os amantes, uma vez que aparece a desordem. Nesse caso, "adiciona violência ao erotismo dos corpos para aquele que experimenta." 3 O sagrado representa " justamente a continuidade do ser revelado aos que fixam sua atenção, em um rito solene, sobre a morte de um ser descontínuo" 4

Outros dois conceitos são primordiais: a interdição e a transgressão. No primeiro caso tem-se as restrições, respeito aos limites, formas sustentadas. Para a transgressão a instauração de rupturas e a quebra das formações das interdições ultrapassar os limites. Esses dois conceitos nas apropriações que fiz tratam da fantasia - no sentido de ficção e máscaras criadas, como produtora da libido.

Cassandra Rios e Márcia X. funcionam como dispositivos para essa pesquisa, porque não somente tratam das formas do erotismo, interditos e transgressões, mas realizam obras que produzem um pensamento artístico que trabalha no limiar entre a captura e o embate de forças. As artistas não apenas reproduzem formas existentes ou invenção de formas, elas investem em fluxos que promovem primeiro uma torção no conceito de corpo para depois refazer o corpo. Essa proposta aparece no pensamento de Artaud e é ampliado por Deleuze: o Corpo sem Órgãos.

A torção a que me refiro é o não pensar no biológico, material. É do corpo como ator das inflexões da cultura e possibilidade de evidenciar torções que ficaram em primeiro plano a partir das experiências de vanguarda. Primeiro plano, pois arte

\footnotetext{
${ }^{2}$ GALANTIN, D. V. Considerações sobre o "erotismo" de Georges Bataille: um pensador do paradoxo e da transgressão, p. 10.

3 Idem, ibidem, p. 10

${ }^{4}$ BATAILLE, G. $O$ erotismo, p. 45.
} 
e sociedade interagem influenciando-se mutuamente. Isso ajuda a marcar a importância de como esses movimentos de vanguarda, cada um a sua maneira, ajudaram a colocar o corpo em uma nova perspectiva. Arnold Hauser pensou sobre a relação que o artista estabelece com a sociedade, "voltar-se para ela, seja para criticá-la, seja para afirmá-la, seja para superá-la"5 promovendo novas formas de expressão. Citar as vanguardas não somente por ser um recurso de escrita, mas sobretudo pelo impacto das "artes neste século ser justamente uma aproximação de todas elas, uma influenciando a outra e concorrendo todas para a popularização de novas técnicas e linguagens." ${ }^{6}$ Segundo Arnold Hauser,

\begin{abstract}
A arte pós-impressionista é a primeira a renunciar, em princípio, a todo o aspecto ilusório da realidade e a exprimir a sua atitude perante a vida, através da deformação deliberada dos objetos naturais. Cubismo [...] futurismo, expressionismo, dadaísmo e surrealismo afastam-se com a mesma decisão do impressionismo ligado à natureza e afirmador da realidade. [...]

A arte moderna é, porém, anti-impressionista ainda noutro sentido: é uma arte fundamentalmente "feia", que foge a euforia, às formas fascinantes, às tonalidades e às cores do impressionismo. [...] Implica uma fuga angustiada de tudo o que é agradável e dá prazer, de tudo o que é puramente decorativo e atraente. ${ }^{7}$
\end{abstract}

Esse fragmento ajuda na organização que fiz de Cassandra e Márcia. Cassandra com sua literatura promove novas formas de subjetividades. A arte de Márcia organiza corpos que não representam um destino, mas colocam em cena a resistência a um domínio em relação à sexualidade. Elas fogem da euforia, pois manejam seus instrumentos - objetos e palavras - de uma maneira que repensam questões fundamentais na sociedade brasileira, consideradas desagradáveis e perversoras.

Elas desorganizam as formas de captura do desejo. Essas produções tratam dos corpos que não se anulam diante do poder do outro. Corpo intensivo é um corpo potencializado de vida, que está na relação com o mundo, com as vibrações do mundo. Um corpo que não está anestesiado, pois elas enxergam novos mundos trabalham com experiências sensíveis, por isso transgridem. Corpos que não têm somente a noção da origem e do fim. Corpos que expõem suas vibratilidades

\footnotetext{
${ }^{5}$ CHAUÍ, M. s/d.

${ }^{6}$ TELES, G.M. Vanguarda europeia e modernismo brasileiro.

${ }^{7}$ HAUSER, A. História social da literatura e da arte, pp. 118-119.
} 
Um corpo vibrátil que "permite acolher o caráter finito e ilimitado do processo de produção da realidade que é o desejo." ${ }^{8}$ Quais são os gestos de deslocamento que promovem esses corpos? A força que atravessa a representação. A fricção do contato com o novo, com outras experiências. A capacidade do corpo de se entregar aos seus desejos. Resistir às dominações. O corpo em movimento para não repetir e sim produzir pensamentos. Um corpo que sustente suas experiências sensíveis. Logo, com outras significações.

Acredito que essas questões são permanentes no meu pensar sobre o corpo. Por isso, em vários momentos não recorrerei somente às teorias e agenciadores acadêmicos, pois na contemporaneidade todos os dias novos debates ou propostas sobre esse corpo estão sendo produzidas. Sendo assim, recortes de jornais, revistas, documentários e acontecimentos que parecem corriqueiros interessam a essa pesquisa.

Quando se trata das questões do corpo intensivo, não posso deixar de marcar que esse olhar começou a partir de Silviano Santiago e seu ensaio Caetano enquanto superastro. A partir dessa leitura, outras foram surgindo e incitando o meu pensamento acadêmico sobre corpo como locus de produção e não de representação. Aqui, nesse texto, a escrita possui em seu início uma justificativa. Escrever uma dissertação de mestrado é não apenas fixar-se nos três processos listados anteriormente. Escrever o Os blocos sessões do CORPO/ O CORPO e seus blocos sensações é pensar no deslizar das formas, na mobilidade dos conceitos e teorias.

Isso não representa uma defesa prévia, mas um alerta de que pensei nesse grande bloco como um espaço para explicitar as minhas questões sobre corporeidade. Talvez possa parecer inadequado para um texto acadêmico, mas acredito que essas páginas são, na verdade, o início de uma pesquisa que irá perdurar como aquilo que move minhas ambições acadêmicas.

Trato como início, pois penso uma Márcia X. um pouco avessa aos textos que li. No caso de Cassandra, as questões evocadas nas suas narrativas são contemporâneas. Como esquecer ou apagar o rastro dessas artistas?

Não há possibilidade, visto que as duas tratam dos corpos onde o "desejo é a vontade da potência”. Corpos delirantes que garantem o funcionamento da realidade. O motivo, retiro de David Lapoujade:

\footnotetext{
${ }^{8}$ ROLNIK, S. CARTOGRAFIA ou de como pensar com o corpo vibrátil, p. 2.
} 
O delírio não acrescenta à realidade social, mas constitui essa realidade e assegura o seu funcionamento. Não se trata apenas de dizer que os delírios do inconsciente são diretamente políticos e sociais, mas de afirmar que todo campo social e político é imediatamente delirante.

Márcia e Cassandra fazem investimentos em torções de conceitos, fetiches, perversões e, por isso, estão em acordo com o proposto por Artaud em Para acabar com o juizo de Deus. A rebeldia de fmaram pensamento que refaz o corpo, pois problematiza e promove novas experiências.

Refazer não é recriar um corpo. Refazer é pensar para além dos imperativos fisiológicos: comer, beber, exercitar-se, dormir, eliminar etc. O refazimento ocorre nos fluxos de energia que hoje operam em diferentes sistemas de produção, circulação e consumo. Esses fluxos de energia possuem modificação com os processos de modernização e capitalização. Dessa forma, não são fixos.

Em certa medida as duas artistas transitam entre o marginal e o maldito. Hélio Oiticica e Lygia Clark refletiram sobre a condição da marginalidade. Vamos a proposição de Hélio:

Quando digo "posição à margem" quero algo semelhante a esse conceito marcuseano: não se trata da gratuidade marginal ou de querer ser marginal à força, mas sim colocar no sentido social bem claro a posição do criador, que não só denuncia uma sociedade alienada de si mesma mas propõe, por uma posição permanentemente crítica, a desmitificação dos mitos da classe dominante, das forças de repressão, que além da repressão natural, individual, inerente à psichê de cada um, são a mais-repressão e tudo o que envolve a necessidade da mais-repressão." ${ }^{9}$

Elas manobram uma matéria viva e mutante e, a partir disso, é possível experimentar e inventar diferentes maneiras de ver o mundo e de agir. De acordo com José Gil, “o sujeito só se transforma em si próprio quando atinge o domínio máximo (na expressão) dos modos de sentir do outro"10

Teorias e seus agenciadores como Deleuze, Preciado, Kiffer, Rolnik, Márcia X, Bataille, Foucault, José Gil, Artaud e outros, ajudam a atualizar as experiências de corporeidade na arte moderna e contemporânea. As experiências corporais explodem para a cultura a partir de 60 , porém alguns artistas já apresentam isso em

\footnotetext{
${ }^{9}$ Oiticica, H. e Clark. L. In Garramuño. F. A cultura como margem, p. 91.

${ }^{10}$ GIL. J. In GÓES, F. e VILLAÇA, N. Em nome do corpo, p. 63.
} 
suas obras anteriormente. Cassandra Rios, cuja potência de escrita corporal foi considerada contracultural, é um exemplo dessa antecipação - uma experiência de corporalidade e de produção de subjetividade.

O reconhecimento dos aspectos institucionais, sociais, econômicos e políticos são importantes para história social da cultura. O conceito de contracultura e as suas torções nas últimas quatro décadas possui um caráter instrumental, subsidiando reflexões e entendimentos dos campos artísticos na cultura brasileira contemporânea. Assim, há o entendimento de que a contemporaneidade se singulariza por sua conexão de ruptura e hibridismo com a temporalidade: passado, presente e o futuro.

Esta pesquisa considera o conceito de contracultura como resistência às forças opressoras, que através de artes performáticas encontra estratégias possíveis para destituir as normatizações de campos da cultura. Podemos ver o conceito contracultura de duas formas: como um modo de vida ou uma experiência geracional. Porém, na contemporaneidade, esse conceito fica restrito à experiência geracional, aos movimentos hippie e Tropicalista, à ditadura militar, às formas e práticas culturais a partir da década de 60 .

Destaco uma escrita corporal do início do século XX que traz como proposta a possibilidade da intensidade a que me refiro em diversos momentos: a possibilidade do corpo como lugar de resistência e proliferação de sensações aparece na escrita plástica de Pablo Picasso.

O corpo como um cenário de escrita do século $\mathrm{XX}$ resgata as artes das vanguardas. Um exemplo dessa perspectiva é a paixão exposta no corpo erotizado do quadro Lesdemoiselles d'Avignon, de Pablo Picasso, 1907, que apresenta um novo conceito de humano. O quadro representa uma transformação no pensamento da arte. Segundo Eliane Moraes:

A perspectiva múltipla do quadro dava substância a uma sintaxe mental do relativismo, da ambiguidade e da dúvida, implodindo o sistema vigente de percepção da arte. Lesdemoiselles d'Avignon foi, como observou Sevcenko, um "atentado de desestabilização da linguagem", desvelando o ilusionismo por meio do qual a arte inoculava na sociedade. ${ }^{11}$

\footnotetext{
${ }^{11}$ MORAES, E. $O$ corpo impossível, p. 61.
} 
A multiplicidade de sentidos, a pluralidade de possibilidades, de perspectivas múltiplas, e não binárias: verdadeiro versus falso. Na imagem, podemos perceber que a potência transformadora do gesto alude a outras forças, outras densidades. O gesto funda uma experiência: uma intenção de possibilidades de novas vivências. Abre espaço para as coisas de outra maneira. Assim como Cassandra e Márcia X., Picasso inaugurou um suporte para sua escrita. Não de acordo com o mito da escatologia: o corpo como sinônimo de sujeira e todas as práticas possíveis para limpálo. Picasso escreve através de losangos, triângulos e sugestionando relação de máscaras africanas e esculturas ibéricas.

Silviano Santiago acredita que "a figuração e o corpo se entrega, pois, ao páthos. E não ao éthos"12. Isso significa que permanece, sobrevive, carrega energia para aparecer em outro momento. Porém, o corpo apresentado por Picasso era a fragmentação da forma e a apresentação do nu. Isso relaciona o trabalho de Picasso a proposta de Cassandra e X. décadas depois. Essas obras, esses corpos como lugar de fronteira, obrigando o olhar a captar sua escrita de uma maneira inovadora. Retomo Silviano,

ao elaborar a obra, o artista impulsiona força que, por não invocar a coerência da harmonia, trabalha a contradição, que desestabiliza a figura humana. Não congrega, desagrega-a. Fragmenta-a. Estilhaça-a. ${ }^{13}$

O apresentado por Picasso é um corpo glorioso, nu, desabrochado. Os objetos pictóricos se revelaram na condição de fantasma, devolvendo o desejo a sua origem para realçar sua força imaginária. A perspectiva do quadro despertou a construção de uma dinâmica que solicita as nossas experiências: perceptivas, motoras, afetivas, sexual etc. Segundo Viviane Matesco:

Os artistas exploraram meios para representar as multiplicidades do desejo, geralmente servindo-se do objeto corpo a fim de evocar temas com gozo e obsessão erótica. O objeto do desejo era prazer para ser saboreado como libertador. Desse modo, os objetos de função simbólica assumiam o lugar de impulsos velados ou sublimados, como recompensa, explicando como grande parte da atividade surrealista pode ser vista como remoção de obstáculos para derrubar as censuras da consciência e se chegar ao inconsciente, ao maravilhoso. ${ }^{14}$

\footnotetext{
${ }^{12}$ SANTIAGO, S. Aos sábados, pela manhã, p. 183.

${ }^{13}$ Idem, ibidem, p. 184.

${ }^{14}$ MATESCO, V. Corpo, imagem e representação, p. 38.
} 
A obra de arte é ativa e calcada na experiência, todavia ela produz pensamento a sua maneira. Picasso, ao retratar as cinco mulheres, se afasta da arte figurativa tradicional. Para Roland Barthes, “a imagem não é expressão de um código, ela é a variação de um trabalho de codificação; não é depósito de um sistema, mas geração de outros sistemas."15. Pablo Picasso revoluciona a arte em 1907 ao não olhar o conjunto de sucessões das formas harmônicas, ele procura tensões, fantasmas. O fantasma se configura pelo trabalho com aquilo que está reprimido, uma interferência nas estruturas - a tensão das formas.

Há o entendimento de que o 'eu' somente existe a partir da concepção que se faz daquele que é o 'outro'. Sendo assim, somente na relação com o outro é que o 'ser' pode se definir. Isso é chamado de alteridade, e é a condição de ser o outro, mas numa esfera cambiante; face a face com o 'outro', o ser passa a perceber a sua própria face. Os fluxos sugestivos de vizinhança de alguns artistas e pensadores do início do século XX visavam a libertação da opressão do passado e a arte como sintoma de destruições.

A arte de Picasso abre espaço para a produção e o consumo de outros corpos, segundo críticos e teóricos de arte, porém a escrita com tradução dos desejos estava presente em ao menos duas linguagens (plástica e performática). A agressão e a sexualidade como matérias-primas para uma arte sem reservas: com caneta e folha ou tinta e tela.

A incongruência visual daquele que nos olha através da obra relaciona-se com o inconsciente. Os corpos, o nu, o sexo, as máscaras, a fragmentação do ser esses elementos apresentam a borda/o limite/a fronteira, uma dimensão fantasmática do desejo humano e da apreensão. Esse ser fantasmado, o outro que se aciona em nós cujos elementos da obra nos olha, apresenta um deslocamento de categorias. Como Silviano defende, desclassifica a concepção clássica de imitação e propõe a de sobrevivência.

O proposto pelas experimentações a partir de Lesdemoiselles d'Avignon não preenche ou mesmo fecha um conceito, uma tendência, mas gera uma inconstância que nos remete para fora, rompendo com as relações estanques. Para Eliane Moraes,

15 Barthes, R. Obvio e obtuso, p. 152. 
Do corpo fragmentado ao corpo ausente - a anatomia moderna desrealizava por completo a forma humana, partindo de uma permanente recusa de fixá-la segundo qualquer possibilidade estável ou consciente. De Bellmer a Aragon, de Breton a Bataille, a época assistiu a esse empenho de dissolução orgânica na estética; o corpo erotizado era lançado à sua fantasmagoria absoluta. ${ }^{16}$

$\mathrm{O}$ poeta tem a fome do absoluto porque durante muito tempo a poesia deu conta das angústias do mundo. $\mathrm{O}$ trabalho de Pablo Picasso rompe com a ideia de sucessão e faz com que o poeta/artista aponte o corpo como fluxo de energias, como mediador de pluralidades, deslocando os sentidos fixos e determinados, assim como Cassandra Rios e Márcia X.

Trazer para Introdução um intercessor das artistas-chave dessa pesquisa é uma maneira de legitimar a necessidade de se pensar a corporeidade. Como já disse, essa explosão ocorre na década de 60 , porém foi incitada não pelas vanguardas em si, mas por artistas que certamente já enxergavam o mundo e seus assentos além das elassifieaçẽes normatizaçẽes.

O texto é composto por três blocos. No primeiro bloco, procurei destacar as teorias que ajudaram a pensar no refazimento do corpo. Além de Bataille outros agenciadores foram incluídos: Foucault e seus estudos sobre biopoder; Artaud e sua transcrição radiofônica; Artur Barrio e sua arte inquietante e o diretor cinematográfico Kechiche e sua adaptação do romance Azul é a cor mais quente. Além disso, alguns fatos, notícias e atualidades que de alguma maneira esbarram na produção dessa escrita também estão presentes.

O segundo bloco marca o comportamento transgressor de Cassandra Rios e todas as suas manobras para tratar da sexualidade no corpo de uma criança que usa uma sandália como fetiche por uma mulher mais velha, uma adolescente e a descoberta do desejo proibido. Num outro plano, fala do corpo de um travesti e as paixões que desperta nos homens. Flávia, Andréa e Ana Maria são personagens criadas em um contexto opressor. Suas protagonistas experimentaram o prazer em um tempo em que não era permitido tratar a mulher como um ser sexual. Esse é o motivo de Cassandra ser transgressora, por abordar questões do controle social sobre a sexua-

\footnotetext{
${ }^{16}$ MORAES, E. O corpo impossível, p. 70.
} 
lidade e corpos femininos. O conceito de biopoder também foi relacionado aos atores sociais, aos tipos de comportamentos que fui encontrando enquanto o meu corpo circulava nas extremidades: de Santa $\mathrm{Cruz}^{17}$ para mundo.

A terceira escrita é a mais questionadora para essa pesquisa, pois entendo as construções de Márcia X. como algo que fala muito mais do que o feminismo legou à escrita dessa pesquisa, para questionar conceitos sobre corpo, biopoder, erotismo e refazimento do corpo alguns recortes foram necessários. Refiro-me à questão da reza sobre a reza, o terço, o pênis do homem negro, a construção de uma ideologia e de outras abordagens que são que inesgotáveis, considerando o modo de operação de $X$.

A dissertação aborda o corpo e suas dimensões plásticas. A escrita a partir de fagulhas que fui encontrando no decorrer de um processo acadêmico. Em alguns momentos, apenas sussurros apareceram, pois pensar o corpo na contemporaneidade é compreender a reinvenção do homem. Compreender as rasuras das identidades que, de acordo com as políticas de agenciamento, promovem estratégias de consumo que agem nas subjetividades.

\footnotetext{
${ }^{17}$ Não sou moradora de Santa Cruz, mas durante o curso de mestrado saía de Santa Cruz para a Gávea semanalmente. Esse trânsito pela cidade possibilitou um pensar sobre a atualidade do conceito de biopoder.
} 


\title{
2- O erotismo e suas questões
}

\begin{abstract}
O corpo é nosso meio geral de ter um mundo. Ora ele se limita aos gestos necessários à conservação da vida e, correlativamente, põe em torno de nós um mundo biológico; ora brincando com seus primeiros gestos e passando de seu sentido próprio a um sentido figurado, ele manifesta através deles um novo núcleo de significação ${ }^{18}$."
\end{abstract}

Pensar as relações do corpo, da sexualidade com o conceito de biopoder é o principal objetivo dessa dissertação. Entender os dispositivos que operam essa trama necessita de uma organização teórica, pois alguns agenciadores de conceitos e corpos vão permear esse trabalho. Inicio com as teorias de Foucault sobre o biopoder, com Artaud e a sua proposta de refazimento do corpo e com Bataille que aborda definições do erotismo.

$\mathrm{O}$ enfoque do corpo envolve necessariamente seu movimento desejante. A partir do momento em que o corpo ganha um destaque na sexualidade, o tema será discutido tendo-se como eixo o conceito de biopoder, apresentado e desenvolvido por Michel Foucault. Esse conceito elaborado na genealogia das relações de poder é abordado por Michel Foucault a partir da década de 70. Sua teoria aparece em 1976 no primeiro volume da História da Sexualidade, porém suas investigações estavam sendo desenvolvidas em seus cursos ministrados no Collège de France: " $E$ ' preciso defender a sociedade”, 1975; "Segurança, território e população”, 1978 e "Nascimento da Biopolítica”, 1979.

Vladimir Safatle ${ }^{19}$ explica as nuances por trás desse conceito. De um lado, "o poder disciplinar, que nos forneceria uma anatomo-política do corpo. Do outro, os controles reguladores, que forneceria uma bio-política - logo, disciplinas do corpo e regulações da população. O biopoder é a junção de anatomo-política e de bio-política."

\footnotetext{
${ }^{18}$ MERLEAU-PONTY, M. Fenomenologia da percepção, p.203.

19 Essa citação está no material divulgado por Vladmir Safatle na internet. Safatle ministrou um curso intitulado Erotismo, sexualidade e gênero em 2014 na USP e gentilmente disponibiliza integralmente para os interessados suas aulas transcritas. SAFATLE, V. Aula 06, p. 5. Disponível em: http://filosofia.fflch.usp.br/en/node/1219; $\quad$ http://usp-br.academia.edu/VladimirSafatle/TeachingDocuments.
} 
Esse encontro acontece no corpo - um espaço de trocas. Para Jorge Glusberg "a utilização do corpo como meio de expressão artística deve ser pensada e discutida como necessidade humana básica ${ }^{20}$ ". Pois, para ele, a forma humana é a mais plástica e flexível das matérias significantes, e a performance ${ }^{21}$ desenvolve verdadeiros programas criativos, individuais e coletivos. Ela é uma comunicação que utiliza novos suportes.

Saqueio de Artaud a transmissão radiofônica, Para acabar com o julgamento de Deus ${ }^{22}$. Seu texto aborda a condição humana no refazimento do corpo. $\mathrm{O}$ mergulho nesse argumento vem através da zona de leitura criada por Ana Kiffer ${ }^{23}$. Kiffer possui um amplo estudo acerca de Artaud, seu pensamento e a trajetória do escritor francês. Sobretudo sobre o questionamento da docilidade, pois, segundo Kiffer, Artaud sofre os efeitos de construção do corpo - ele não se adequava. A pesquisadoras das Genealogias do corpo aponta que o para o teórico, deveria ser menos organizada a construção dos corpos. Isso aparece linguagem de Artaud como uma discursividade poética e atua no seu pensar sobre os corpos. A exemplo disso para Kiffer as cartas de Artaud: ele atribui as suas cartas o poder mágico de quem as recebe. O destaque do trabalho de Ana Kiffer é importantíssimo nessa pesquisa, uma vez que encontrei no seu texto o recorte temático que agora desenvolvo aqui: a possibilidade de refazimento do corpo; o corpo atuando em novas experiências. O corpo sendo refeito pela sexualidade.

A transcrição de Artaud, datada em 1948, tem grande impacto na época e na atualidade, pois estabelece uma nova proposição em relação à construção do que entendemos dos mecanismos que domesticam o corpo e a experiência. Para refazer o corpo é necessário que se recriem as experiências. Outros autores e artistas também nos convidam a isso: uma escrita sem mediação.

Outro texto de Artaud novamente nos convoca a pensar o corpo e suas torções. Sua teoria sobre o Corpo sem Órgãos determina, a sua maneira, que o corpo não é um organismo coerente. Isso aparece quando ele leva até o último grau as

\footnotetext{
${ }^{20}$ GLUSBER, J. A arte da performance, p. 51.

${ }^{21} \mathrm{O}$ termo performance que aparece aqui, não trata do desenvolvimento do corpo e sim de uma nova atuação nos campos artísticos. Em outro momento, esse conceito será desenvolvido, pois é de total importância no que se refere ao tipo de obra que é cultivado por Márcia X. a partir da década de 80. 22 ARTAUD, A. Para acabar com o julgamento de Deus, 1948. Disponível em: http://www.psb40.org.br/bib/b75.pdf

${ }^{23}$ KIFFER, A. O que é preciso para se refazer o corpo?, pp. 203-210.
} 
experiências, pois ele destitui o corpo de suas partes mais vitais. Dessa forma, alguns assentos que estavam organizados começam a refazer a relação de corpo e pensamento. A hipótese de Artaud é trabalhada por Deleuze. Destaco do livro Mil Platôs ${ }^{\mathbf{2 4}} \mathrm{um}$ fragmento que desdobra a teoria apresentada inicialmente nos anos 30:

O organismo não é corpo, o $\mathrm{CsO}$, mas um estrato sobre o $\mathrm{CsO}$, quer dizer, um fenômeno de acumulação, de coagulação, de sedimentação que lhe impõe formas, funções, ligações, organizações dominantes e hierarquizadas, transcendências organizadas para extrair trabalho útil.

Tal especulação possui correlação com a precariedade dos corpos nos movimentos de resistência. Deleuze desdobra em outros dois textos ${ }^{25}$, além do citado no fragmento acima, a atuação intensiva da noção de corpo após as questões de Artaud sobre o CsO. Esses estudos interessam a pesquisa, porque a sexualidade investe nos corpos uma questão para além dos ciclos orgânicos impostos, portanto, sua atuação intensiva. A abordagem de possíveis mudanças nos ciclos orgânicos do corpo masculino é encarada como algo normatizado, já que esse corpo possui um funcionamento que pode ter uma alteração sem questionamentos. Os corpos das mulheres e das crianças pertencem a outras normatizações. Diferente dos homens, esses corpos não são autorizados a transgredir comportamentos que foram cristalizados pelo tempo nas relações sociais. Os pertencimentos sobre sexualidade no corpo da criança e da mulher na sociedade são produzidos a partir de marcas significantes. O corpo da criança ou da mulher não era refeito e sim subjugado pelas leis da heteronormatividade. Artaud não faz distinção de gênero no seu refazimento, e, talvez por isso, as questões mais radicais ou transgressivas apareçam através do corpo da mulher.

De Bataille me aproprio de suas investigações, sua escrita, seu pensamento construído a respeito das definições de erotismo. Tais como ${ }^{26}$ :

O que está em jogo no erotismo é sempre uma dissolução das formas constituídas. Repito-o dessas de vida social, regular, que fundam a ordem descontinuada das individualidades definidas que somos (...) Trata-se de introduzir, no interior de um

\footnotetext{
${ }^{24}$ DELEUZE, G. Mil Platôs: capitalismo e esquizofrenia 2, p. 24.

25 "As máquinas desejantes" do livro O anti-Édipo; o capítulo que possui o título "28 de Novembro de 1947 - Como criar para si um corpo sem órgãos" do livro Mil platôse o capítulo" A histeria" que está no livro Francis Bacon: a lógica da sensação.

${ }^{26}$ BATAILLE, G. $O$ erotismo, pp. 42-43.
} 
mundo afundado sobre a descontinuidade, toda a continuidade que esse mundo é capaz (...) A própria paixão feliz acarreta uma desordem tão violenta que a felicidade de que se trata, antes de ser uma felicidade de que seja possível gozar, é tão grande que se compara a seu contrário, ao sofrimento. (Grifo meu)

Para Bataille, erotismo é comunicação. E não há como pensar o erotismo sem compreender a fabricação de corpos da sexualidade. Ordenar um corpo pelo seu desejo sexual é retornar no tempo e no estabelecimento do quadro das perversões. Um exemplo dessa questão é a homossexualidade ser tratada como doença até os anos 90 do século $\mathrm{XX}^{27}$. Outra questão que se torna importante é a distinção entre os conceitos oriundos da sexualidade: o erotismo e a pornografia.

Eliane Robert Moraes apresenta um discurso no qual afirma que há uma questão mercadológica envolvendo tanto o erotismo quanto a pornografia, uma vez que suas fronteiras não são bem definidas. Em 1984, no livro O que é pornografia, a pesquisadora considera que há uma distinção entre esses conceitos, porém após anos de estudo sua afirmação é categórica ${ }^{28}$ : trata-se de uma questão mercadológica, pois há o apelo moral. A exemplo disso, trago para o debate quatro casos de censura do corpo.

Muitos debates acalorados no Brasil têm sido estabelecidos em relação a essa temática, como a extensa e desgastante cisão intelectual do pesquisador Jorge Coli com a Academia Brasileira de Letras, em 2012.

Como falar do corpo e não abordar a sexualidade na contemporaneidade? Acompanhando as mudanças no campo cultural, antropológico, filosófico, a produção de pensamento em vários campos do saber produz incessantemente práticas discursivas - definida por Foucault ${ }^{29}$ como um agrupamento de "regras anônimas, históricas, sempre determinadas no tempo e no espaço, que definiram, em uma dada época e para uma determinada área social, econômica, geográfica ou linguística, as condições de exercício da função enunciativa" que são refletidas no corpo.

\footnotetext{
${ }^{27}$ Em 17 de maio de 1990, a Organização Mundial da Saúde (OMS) retirou a homossexualidade da lista de doenças mentais do Código Internacional de Doenças. A decisão também eliminou o uso do sufixo 'ismo', desvinculando a orientação sexual da ideia de enfermidade. A data é tão memorável que passou a marcar o Dia Internacional de Combate à Homofobia. http://www.emdialogo.uff.br/content/ha-23-anos-homossexualidade-deixava-de-ser-consideradapela-oms-uma-doenca-mental ${ }^{28} \mathrm{https} / / / \mathrm{www}$. youtube.com/watch?v=oqasXWtpxBk

${ }^{29}$ FOUCAULT, M. A arqueologia do saber, p. 133.
} 
Jorge Coli, assim como Charles Baudelaire ${ }^{30}$ e Édouard Manet ${ }^{31}$, teve seu trabalho censurado por apresentar o quadro “A origem do mundo”, de Gustave Coubert, de 1866, no telão do anfiteatro da Academia Brasileira de Letras e usar a palavra "boceta" na conferência "O sexo não era mais o que era”. O fato foi amplamente discutido e abordado pelo jornal $O$ Globo, em 23 de setembro de 2012, pois a $\mathrm{ABL}$ entendeu que o conteúdo verbal e pictórico era inadequado, segundo matéria assinada pelos jornalistas Joana Dale e Roberto Kaz, da Revista $o$ Globo. As reclamações e a projeção do fato não pararam por aí, pois na edição seguinte houve intensa manifestação na seção Cartas, bem como muita repercussão pela capa e pela matéria veiculada. Muitos reclamavam da ousadia, porém outros parabenizavam a coragem.

O estreitamento com novos campos da cultura, o embate nos inúmeros suportes, a concepção de mobilidade da identidade relacionada com a sexualidade é atuante. Além de ser destaque na literatura, nas artes e na política, a tensão existente nas formas de apresentar o corpo, a nudez e a sexualidade chega às capas dos discos. Novamente encontro nas publicações do Segundo caderno do Jornal $O$ Globo uma zona de contato com o objeto dessa pesquisa. Na primeira semana de julho de 2015 o veículo apresenta: Manda "nudes" - O corpo nu ganha destaque nos discos da nova música brasileira e, mesmo 50 anos após a revolução sexual, ainda provoca reações moralistas e censura; artistas analisam a nudez real e metafórica ${ }^{32}$.

O grupo Jota Quest, a cantora Juçara Marçal e o artista Jonas Sá tiveram seus trabalhos censurados. Todos pelo mesmo motivo: a capa dos álbuns possuía imagens que desrespeitavam os bons costumes, a moralidade.

No caso do grupo Jota Quest, a censura deve-se à imagem ${ }^{33} \mathrm{de}$ uma mulher nua, dentro de uma taça de Dry Martini, com uma parte do seio à mostra - no $C D$ Funky Funky Boom Boom. Já para Juçara Marçal, a questão é mais incisiva, pois ela teria que mudar a capa do seu trabalho Encarnado ${ }^{34}$ porque uma mama aparecia. Como a artista não cedeu a imposição, foi castigada: não está no iTunes. O cantor e compositor Jonas Sá recebeu uma dupla punição. Seu trabalho não estava apenas

\footnotetext{
${ }^{30}$ Baudelaire foi julgado pela corte francesa devido a seis poemas que foram considerados obscenos. Os textos fariam parte de seu livro - As flores do mal.

${ }^{31}$ Referência ao quadro Olímpia, 1863 de Édouard Manet.

${ }^{32}$ http://oglobo.globo.com/cultura/musica/corpo-nu-ganha-destaque-nos-discos-da-nova-musicabrasileira-provoca-reacoes-moralistas-censura-16665408

${ }_{33}$ Autoria do pintor americano Mel Ramos, considerado um dos ícones da pop art.

34 Trabalho feito pelo guitarrista Kiko Dinucci.
} 
sendo questionado pela capa de um disco, como também pelas suas letras, consideradas obscenas.

Em meio a tantos lançamentos, enunciações, a capa do CD Guela ${ }^{35}$,da cantora Maria Gadu, não sofreu a mesma repressão do iTunes. Logo, a posição de Moraes se torna reflexiva e ao longo desse trabalho será citada em diversos momentos. O que opera nesse jogo é o poder dos mecanismos de servidão maquínica, marcado por um sistema retro alimentador. A questão mercadológica está acima da moral, pois não há embasamento para a diferença dos corpos que transgrediram o brio. Ao mesmo tempo em que há uma condenação de um importante pesquisador - e de artistas que podem ser chamados de alternativos, pois atuam em outro circuito comercial -, existe a liberação de uma artista consumida pelo mercado fonográfico que é vendido no horário nobre da televisão, nas rádios populares.

A nossa condição de se despir ou de se apresentar nu não é apenas uma questão estética. As políticas que operam esse jogo colocam o corpo como "um permutador de códigos" ${ }^{״ 3}$. As trocas que são realizadas ocorrem em corpos que interessam ser apresentados, consumidos, reproduzidos. Assim, temos uma torção no verbete permuta, uma vez que não temos uma troca justa e igualitária. O que também vai determinar que outras classificações (belo, feio, bom, ruim) sejam submissas a esse mesmo tipo de permuta.

Os Estudos Culturais consideram que, desde as vanguardas culturais, no início do século XX, novas formas de ver o mundo e seus assentos imprimem uma dinâmica radical em diversos campos da cultura. As vanguardas culturais possuem como premissa que a arte do século anterior desqualifica a representação do novo mundo que se inaugura no século XX e que todas têm o projeto de levar à reflexão e à ação por meio da arte. Sendo assim, imagens agradáveis, criadas para produzir prazer estético devem ser suprimidas do universo artístico, já que preconizam que a arte é uma mera expressão de belas formas ou palavras. Também pela mesma razão a linguagem literária precisa se transformar em tema e objeto da arte, porque os jovens artistas estão dedicados em criar novos métodos que permitam a exploração máxima do poder de representação e significação da palavra. Dessa forma, há

\footnotetext{
${ }^{35}$ Capa realizada pela artista visual Catharina Suleiman.

${ }^{36}$ MATESCO, V. Corpo, imagem e representação, p. 13.
} 
um interesse em um movimento de vanguarda - o surrealismo, pois Artaud e Bataille operam alguns pensamentos na zona de leitura criada por essa vanguarda. Nas palavras de Vladimir Safatle ${ }^{37}$ :

Podemos definir um dos eixos centrais do surrealismo como a crítica da realidade social em prol de uma sobre-realidade na qual encontraríamos o que teria sido recalcado pelos processos de racionalização na modernidade, como inconsciente, o infantil e o arcaico. Nesse sentido, a experiência modernista é um paradoxal apelo à recuperação do que foi expulso do nosso tempo histórico. Recuperação da capacidade de escrever como uma criança, sem objetivo e em completa errância; escrever com as condensações, os deslocamentos e as associações próprias às formações do inconsciente; escrever deixando retornar experiências sociais que a modernidade quer marcar com o selo do arcadismo. Dentro desse horizonte, a posição de Bataille consiste em explorar tal retorno do recalcado através de uma reflexão sobre a potência de uma escrita da transgressão. (...) A arte aparece como uma experiência marcada pela procura em sintetizar novas formas capazes de nos desacostumar de uma realidade que, longe de ser naturalizada, é uma construção social responsável pelo empobrecimento do homem moderno. (Grifo meu)

Entretanto, não apenas esse movimento vai desestabilizar o comportamento do século anterior. As grandes guerras, o surgimento de conceitos como happening, performance, o pós-estruturalismo, o pós-modernismo, o multiculturalismo e todas as mortes: do autor, de Deus, da arte, do espectador, do sujeito vão contribuir para que as teorias dos três agenciadores iniciais de corpos - Artaud, Foucault e Bataille - possam permanecer tão atuantes. Em certa medida, é como se cada um em sua época pudesse atravessar o tempo e reconhecer potências que seriam vivenciadas no final do século XX e no século XXI.

A contemporaneidade apresenta algumas questões, tais como as considerações feitas por Lawrence Cahoone ${ }^{38}$, quando este propõe cinco temas: 1) crítica da presença ou da apresentação, em favor da representaçãa $o^{39}$; 2) crítica da origem,

\footnotetext{
${ }^{37}$ SAFATLE, V. Aula 02, p.03.

${ }^{38}$ CAHOONE, L. In Cardoso, C.F. Epistemologia pós-moderna: A visão de um historiador, pp. 75-90.

${ }^{39}$ Segundo Ciro Flamarion, "O pós-modernismo questiona e às vezes rejeita esta distinção. Nega que qualquer coisa esteja 'imediatamente presente' e seja, assim, independente dos signos, da linguagem, da interpretação, das diferenças de opinião etc. Em alguns casos, argumenta que a apresentação de fato pressupõe a representação. (...) A negação da presença leva ocasionalmente os pósmodernistas a substituir a discussão da coisa pela análise das representações da coisa. (...) A crítica da presença, às vezes, é expressa pela frase 'Não há nada fora do texto'. Isto não precisa significar que o mundo real não exista; mas, sim, que nós só encontramos referentes com que possamos lidar
} 
em favor de fenômenos; 3) crítica da unidade, em favor da pluralidade; 4) crítica das transcendências das normas, em favor da imanência; 5) análise dos fenômenos mediante a alteridade constitutiva.

Não somente por essas propostas e, principalmente, pelos novos estudos em vários campos do conhecimento, o corpo, juntamente com a arte, sai da categoria de vivido e vai para algo que ainda não pode ser narrado. A linguagem como forma de organização não dá conta do que está acontecendo. O homem que acompanha e aceita essas transformações reorganiza sua maneira de ver o mundo e os seus sustentos. Um dos conceitos que sofre esse impacto é o da sexualidade que, a partir da década de 60 do século XX, começa a ser rasurado, assim como o de corpo pois vem sofrendo fortes críticas.

Com a crítica radical à Modernidade, os controles dos corpos e sentidos são tensionados nos últimos 40 anos pelas ciências sociais. Sendo assim, o corpo, a sexualidade e a produção de subjetividade são destacados em muitas teorias. O sexo, a sexualidade vai ser usado como forma de rebeldia. Logo, há grandes questionamentos, por isso aponto a rasura.

O reconhecimento dos aspectos institucionais, sociais, econômicos e políticos são importantes para história social da cultura. O conceito corpo e as suas torções nas últimas quatro décadas possuem um caráter instrumental, subsidiando reflexões e entendimentos dos campos artísticos na cultura brasileira contemporânea. Assim, há a percepção que a contemporaneidade singulariza-se por sua conexão de ruptura e hibridismo com a temporalidade: passado, presente e o futuro.

A radicalidade das experimentações artísticas, que privilegiam o corpo, a sensação e a participação do espectador, contaminam o pensamento que, ao reformular-se, dá destaque aos temas referentes ao corpo enquanto comunicação da pessoa com o mundo. A altivez trabalhada e exposta por alguns artistas criou dois conceitos importantes nesse processo: a performance e o happening.

Nas décadas de 60 (fins) e 70, o termo performance passou a ser explorado pelo campo da literatura, da arte, da música, do teatro e da dança e resultou em um gênero como expressão que dialoga frequentemente como a eventualidade, com a

através de textos ou de representações, ou seja, mediados. Nunca podemos dizer o que independe de qualquer dizer."

Ibidem 
quebra ou a diminuição da distância entre espectador, artista e obra de arte. O espectador é capaz de percorrer a obra com o olhar e essa pequena captação.

A performance é resultado de uma série de manifestações artísticas que ocorreram em $1940^{40}$ e 1960. Para Antônio Herculano Lopes ${ }^{41}$ :

\begin{abstract}
O uso da força da performance nas análises de história da cultura permite um olhar novo sobre certos fenômenos que já foram esquadrinhados através de prismas diversos. Em cada situação histórica concreta, indivíduos e grupos projetaram anseios, marcaram posições e constroem imagens de si e de seus 'outros' e da sociedade envolvente através de formas pelas quais se apresentam e atuam publicamente, dentro de estruturas mais ou menos ritualizadas. O uso de linguagens corporais, técnicas retóricas, expressões faciais, manipulação das emoções, regras de procedimento coletivo, decoração visual do corpo e do espaço - só para citar alguns elementos performáticos - em manifestações públicas contribuem para a construção de identidades coletivas que ao mesmo tempo refletem e influenciam o curso dos eventos.
\end{abstract}

O corpo em contrapartida começa a ser afetado pelos espaços e pelas atrações e esses, por sua vez, causam uma erosão nas vidas. O status do corpo acompanha essa transformação e um novo conceito começa a ser trabalhado a partir de tais proposições no campo das artes: o happening.

Pensar na representação da escrita de um eørpø, na mudança de máscaras que vão contando/construindo uma história, que vai atuando. Que se encaixa no momento que aqui escrevo exatamente como um corpo entremeado que representa várias experiências. $\mathrm{O}$ corpo de quem escreve o aqui e o agora é a partir de um pensamento fraturado, refeito, com tensões que não chegam a um objeto fechado e pensado linearmente. Ele representa algumas vozes que se complementam e outras que se repelem.

Compor um corpo: aproximar duas artistas, duas linguagens, dois conceitos tão desnivelados. Esse texto não é para falar de mulheres na arte; nem de produções femininas. É um texto que fala do corpo como protagonista das dobras/mudanças da cultura, de corpos que se fazem, desfazem ou refazem nas novas formas de pensar e entender a sexualidade como política. Dentro dessa zona de leitura, a ponte

\footnotetext{
${ }^{40}$ Alguns historiadores e críticos de Arte apontam o início desse processo na década de 40.

41 LOPES, A.E. Performance e história, p. 07.
} 
artística conceitual possui como base a indagação: Como o conceito de erotismo e os discursos sobre biopoder poderiam refazer o corpo?

Essa indagação confronta a linguagem verbal usada por Cassandra Rios em seus romances e a linguagem plástica trabalhada nos objetos, performances e instalações por Márcia X. para observar as formas diferentes de tratamento artístico da força explosiva da sexualidade. Nesse enfrentamento, os questionamentos basais que serão desenvolvidos estão centrados nas obras de Cassandra Rios - Eu sou uma lésbica, Uma mulher diferente e As traças; e Márcia X. - Fábrica Fallus, Desenhando os terços e Os KaminhasSutrinhas.

Escolho um texto para iniciar a reflexão crítica em relação aos corpos como produção de modos de vida. O primeiro dispositivo deste capítulo a ser usado é a publicação: Sobre limites e corpos extremos, de Ana Kiffer ${ }^{42}$ :

\begin{abstract}
Numa vertente, 'corpo extremo' é um operador conceitual que permitiria debater com conceitos chaves para compreensão de um certo universo da arte que se relaciona com a manifestação de situações limite, e por outro lado, 'corpos extremos' manifestam-se enquanto dados materiais que fazem com que na formulação artística ou do próprio pensamento uma dada situação se metamorfoseia noutra.
\end{abstract}

Pensar os corpos ou a arte de acordo com as últimas vivências e manifestações sobre o campo da cultura que é intitulado de sexualidade é algo muito potente, pois no final do Século XX e início do XXI muitas transformações foram estabelecidas. Nesse sentido, a proposição de corpos através da sexualidade está diretamente vinculada ao proposto por Kiffer, pois operam no limite dos significados e provocam a atuação desses conceitos.

Tratar da sexualidade como algo estético é o embate entre o corpo orgânico e o sentido sem materialidade que esse corpo produz. Isso pode ser visto nas novas formas da sexualidade, nos estudos acerca dos gestos, dos limites e dos significados em campos culturais que até o século passado não estavam atrelados à sexualidade e não produziam narrativas sensoriais. Operando nos eixos da história cultural, a sexualidade não pode deixar de ser discutida, pois transforma-se em um objeto importante na busca pelo entendimento dos inúmeros e possíveis significados das relações humanas e coletivas.

\footnotetext{
${ }^{42}$ KIFFER, A. Sobre limites e corpos extremos, p. 23.
} 
O ideal de comportamento e a prática de comportamentos - que, a partir do fim da década de 60 e, principalmente, ao longo da década de 70 colocam a sexualidade como um campo de investigação das ciências humanas - geram novos suportes de controles e transgressões: a pílula, a emancipação da sexualidade feminina (arrisco a propor), as influências dos movimentos que imprimiram uma nova mentalidade em torno do sexo e os novos enfrentamentos acerca do conceito de gênere.

É importante destacar para essa pesquisa: anteriormente esses objetos e temáticas foram ignorados pelo conhecimento acadêmico - Isso será visto com maior clareza através de Márcia X.. A mudança na forma de comunicação possibilita uma nova linguagem que coloca o corpo como protagonista das inflexões da cultura. Logo, a ideologia da liberação do corpo tem muita projeção na revolta contra a autoridade imposta nas representações e suas referências morais e éticas do nosso tempo.

Diversos modelos atravessam os nossos próprios corpos diariamente, alguns sem a intenção de estabelecer uma relação direta, outros pensados minuciosamente para adentrar em nossas utopias. Portanto, seria uma negligência não destacar alguns momentos de nossa construção cultural e nas táticas de refúgio - meios que criam novas formas de organização, entre desejo e política que estabelecem um território de transgressão.

Antes de desenvolver Cassandra e X. trago para essa pesquisa uma experiência cinematográfica que transgride as normas, pois trata o corpo de forma experimental: é o filme Azul é a cor mais quente ${ }^{43}$. De acordo com Hélio Oiticica, experimental, pois não é colonizado. A questão não é problematizar esteticamente o filme. O que interessa é a potência política com que é tratada a sexualidade. Essa questão envolve duas obras: um filme e um livro. A novela gráfica de Julie Maroh - adaptada para o cinema por Kechiche -, é vista como uma experiência que atravessa as esferas das instituições e da subjetivação, enquanto produção de formas de vida e organização social.

A apropriação do conceito de sexualidade, nessa estrutura da narrativa, é pautada na desorganização de um corpo a partir de uma linguagem instigante. Sua escrita $^{44}$ desafia nossa possibilidade de pensamento, entretanto desperta novos sen-

\footnotetext{
${ }^{43}$ Filme inspirado na H. Q. - Romance gráfico - da autora francesa Julie Maroh.

${ }^{44}$ Chamo de escrita a forma como AbdellatifKechiche escolheu contar essa história.
} 
timentos, novas sensações. A apresentação dos corpos - sem maquiagem, com longas cenas em que se percebe o forjamento da emoção, o enquadramento nos corpos, a comida sendo revirada na boca, o nariz escorrendo, a lentidão nos movimentos, os gestos - tudo contribuindo para a desorganização não só de um corpo, como também de vários paradigmas que desestabilizam a limpeza e submissão impostas pela cristandade.

No nosso contexto, além de todas as críticas e espectadores abandonando a exibição, temos a proibição do filme em Blu-ray pela tecnologia ser considerada uma evolução para aproximar o espectador da realidade. Logo, temos a coibição de uma obscenidade hiper-realista, pois a arte em questão extrapolou os conceitos de eretisme pernegrafia. Sendo assim, é taxada como obscena.

A produção de conhecimento implica a transgressão de uma cultura imposta pela disciplina, pela violência e pela censura. $\mathrm{O}$ discurso cinematográfico escolhido verticaliza o debate crítico proposto, pois é considerado como fora dos padrões. Esse julgamento resulta da ruptura radical das regras coercivas da moral social ainda tão estagnada no século XXI. A estagnação gera uma série de discursos sobre intolerância e trava batalhas épicas ao redor do que ainda é considerado tabu.

O idealizador do filme, Kechiche, provoca os mecanismos que domesticam a experiência. Isso ocorre não só pelo esgarçamento da linguagem, como também pelo enfrentamento do que é considerado escatológico - o sexo durante anos apoiando-se na formação cristã considerado sujo. O questionamento da docilidade para Artaud: a merda, as fezes; para Kechiche: o sexo explícito em uma cena de aproximadamente 11 minutos.

Saber se Azul é a cor mais quente contaminou ou vai contaminar as produções seguintes não cabe nessa escrita, porém ele refez o corpo através da sexualidade. Não cabe afirmar que tenha produzido uma novidade, mas merece atenção a maneira como a colocou. E sim, a maneira como foi posto: o tempo usado a favor dos gestos, da movimentação daqueles corpos, o argumento para uma nova forma de aceitação do desejo que desestruturou categorias e vetores de força. 
Pensar nos gestos ${ }^{45}$ é ir ao encontro da pesquisa de Eliane Bortolanza - os gestos são linhas de fuga, devires imperceptíveis, encadeamentos, pequenas fissuras, fendas, abertura para o movimento dos corpos, movimento de si e entre os corpos, pois há a provocação da materialidade e a determinação de tornar as forças visíveis. É uma interrupção no modo de olhar. É uma pausa que rompe algo no sujeito para a abertura de outra razão. O gesto principiou um espaço para a aceitação do desejo, como agente de significação.

Houve uma torção no conceito de sexualidade na escrita expandida ${ }^{46} \mathrm{de} A z u l$, uma vez que as classificações tradicionais não deram conta de ordenar o discurso. Escrita expandida no sentido da ampliação da concepção clássica de escrita, sua expansão devorou o mundo, pois colocou em cheque as categorias anteriormente estabelecidas para um recurso audiovisual. É importante salientar que o filme conquistou 11 prêmios e a vendagem do romance gráfico alcançou bons números de venda no mercado.

O filme constituiu um espaço de experimentação em que se questionam os controles sociais que incidem sobre a força revolucionária do desejo no campo cinematográfico. Esse embate é um campo fértil na produção de subjetividades em torno do sexo. Vladimir Pinheiro Safatle trata o sexo da seguinte forma:

O sexo é objeto do discurso filosófico quando ele aparece como um evento. E a boa questão talvez seja: em que condições "sexo" e, principalmente, falar de sexo pode aparecer como um evento, como um acontecimento capaz de produzir reconfigurações profundas em nossa forma de vida ${ }^{47}$.

O acontecimento é aquilo que é recusado pelo estruturalismo e pela hermenêutica, pois escapa da história e da contextualização. Rompe com o espaço, com a temporalidade e possui um poder imediato de desorganização sob estratos mais rígidos. Porém, não é uma categoria permanente, pois “o acontecimento é o vapor que sai dos estados de coisas, não se confundindo com elas ${ }^{48}$ ". O filme é um acontecimento por aumentar a produção de discursos acerca do corpo sexual.

\footnotetext{
${ }^{45}$ BORTOLANZA, E. C. Gestos pornográficos: desejo, estética e erotismo, p. 6.

${ }^{46}$ Escrita expandida no sentido da ampliação da concepção clássica de escrita, sua expansão devorou o mundo, pois colocou em cheque as categorias anteriormente estabelecidas para um recurso audiovisual. É importante salientar que o filme conquistou 11 prêmios e a vendagem do romance gráfico alcançou bons números de venda no mercado.

${ }^{47}$ Safatle, V. Aula 01, p. 4.

${ }^{48}$ NABAIS, C.P. Filosofia, Arte e Ciência: modos de pensar o acontecimento, p. 2.
} 
Se o nosso corpo possui mecanismos que domesticam a experiência, como é abordado por Kiffer em seus discursos sobre o corpo, o proposto por Kechiche quebra e refaz essa dominação, uma vez que destitui, questiona as formas de organização dessa linguagem, considerada obscena, tanto pela crítica como pelos espectadores em geral.

Partindo dessas proposições, a linguagem escolhida é um sintoma às agressões simbólicas das opressões ao corpo, na mesma medida em que ela é uma estratégia para destituir as normatizações sobre sexualidade; destitui a forma de corpos femininos e explicita formas não abordadas no circuito comercial de cinema.

A nudez de uma forma desfaz a estética corporal imaginada. A representatividade de um corpo desnudo, de acordo com Jeudy ${ }^{49}$, é da "morte do desejo", pois no cotidiano os referentes para essa nudez são estereotipados - há um padrão que castra a espontaneidade.

Então, o que seria o despir o corpo para fazer amor? Na perspectiva de Foucault ${ }^{50}$ :

Talvez, seria preciso dizer também que fazer amor é sentir seu corpo se fechar sobre si, é finalmente existir fora da utopia, com toda sua densidade, entre as mãos do outro. Sob os dedos do outro que te percorrem, todas as partes invisíveis do teu corpo se põem a existir, contra os lábios do outro os teus se tornam sensíveis, diante de seus olhos semiabertos teu rosto adquire uma certeza, há um olhar finalmente para ver tuas pálpebras fechadas. Também o amor, assim como o espelho e como a morte, acalma a utopia de teu corpo, a cala, acalma, a fecha como uma caixa, a fecha e a sela. É por isso que é um parente tão próximo da ilusão do espelho e da ameaça da morte; e se, apesar dessas duas figuras perigosas que o rodeiam, se gosta tanto de fazer amor é porque, no amor, o corpo está aqui.

Há uma transgressão das normas patriarcais impostas - apresentar dois corpos femininos em momento prazer - completamente nus. É muito importante notar que eles não aparecem sendo despidos. As amantes entram em cena sem vestes, mulheres donas de seus desejos. Encontro em Viviane Matesco ${ }^{51}$ a explicação de dois conceitos que são fundamentais para o até então apresentado: “O nu distingue-

\footnotetext{
${ }^{49}$ JEUDY, H.P. O corpo como objeto de arte, p. 71.

${ }^{50}$ FOUCAULT, M. O corpo utópico, as heterotopias, p. 13.

${ }^{51}$ MATESCO, V. Corpo, imagem e representação, p. 26.
} 
se do desnudar-se. $\mathrm{O}$ nu representa o corpo remodelado, desabrochado. $\mathrm{O}$ desnudar significa que há um embaraço, pois o corpo está privado de vestes".

Nesta investigação que procura os indícios de um corpo que se refaz na dimensão erótica privilegiada pela linguagem cinematográfica, não poderia deixar de me questionar sobre as possíveis passagens que se inscrevem no corpo. O filme nos impõe um ritmo tão violento, que aceitamos ou rejeitamos aquilo que está nos atravessando. Não existe a possibilidade do meio do caminho.

Nesse processo, alguns posicionamentos merecem destaque, pois isso fortalece a legitimidade da pesquisa. Esse objeto de estudo necessita de dispositivos para sustentar o debate crítico e pensar as novas formas da sexualidade que constroem uma arena mais ampla na micropolítica ${ }^{52}$. Esse primeiro conjunto de questões - que investe nas teorias que apresentam as inflexões do corpo ao qual retornamos constantemente - também funciona como um artefato, uma vez que na contemporaneidade temos uma vida, um corpo e um discurso politizado que se desdobram em múltiplos suportes. O filme Azul é a cor mais quente, assim como inúmeras outras escritas artísticas, nos parte em mil pedaços para nos submeter ao refazimento que Artaud nos apresentou no início do século passado:

Quem sou? De onde venho? Eu sou o AntoninArtaud E basta dizê-lo, Como sei dizê-lo, Imediatamente Vereis o meu corpo atuar Voar em estilhaços E em dois mil aspectos notórios Refazer

Um novo corpo Onde nunca mais Podereis

Esquecer-me. ${ }^{53}$

\footnotetext{
${ }^{52}$ A Micropolítica a que me refiro aqui não possui relação com o pequeno, o que é menor e sim ao conceito desenvolvido por ROLNIK, S.Cartografia sentimental - transformações contemporâneas do desejo, p. 60. Segundo Rolnik, "Micro é a política do plano gerado na primeira linha: cartografia. O princípio da individuação, neste caso, é inteiramente outro: não há unidades. Há apenas intensidades, com sua longitude e sua latitude; lista de afetos não subjetivados, determinados pelos agenciamentos que o corpo faz, e, portanto, inseparáveis de suas relações com o mundo".

${ }^{53}$ ARTAUD, A. (tradução de Aníbal Fernandes). Eu, AntoninArtaud, p.111. Xerox.
} 
Muitas encenações transgressoras e novos atores aparecem no cenário político-social do país. Nosso cenário, não só desde junho de 2013, é marcado por uma violência física, pela miséria ética e moral. Acredito que nos debates acerca da corporeidade, não só as artes, a literatura e as ciências de modo geral podem fazer parte dos novos modos de vida que nos obrigam à insurreição de um corpo social e individual. A sexualidade é uma esfera da politização do corpo, de novas forças fundadas, novos corpos fabricados.

A tentativa, não de um refazimento, mas da fabricação de um corpo, nos opõe à utopia ${ }^{54}$. A utopia não tem materialidade, são histórias impossíveis, pois não tem como validar. De acordo com Foucault:

\begin{abstract}
A utopia é um lugar fora de todos os lugares, mas um lugar onde eu teria um corpo sem corpo, um corpo que seria belo, límpido, transparente, luminoso, veloz, colossal na sua potência, infinito na sua duração, solto, invisível, protegido, sempre transfigurado; pode bem ser que a utopia primeira, a mais inextirpável no coração dos homens, consista precisamente na utopia de um corpo incorporal.
\end{abstract}

Márcia X., quando aparece no cenário artístico na década de 80, radicaliza a fabricação de corpos com suas instalações e performances que imprimem uma tentativa de construir um novo corpo, já que profana dois campos intocáveis da nossa cultura: os símbolos religiosos e os que nos remetem à infância. X. usa o lúdico e a fé como temática em diversos momentos de sua construção como artista atuante no cenário cultural brasileiro.

A $19^{a}$ Parada do Orgulho LGBT de São Paulo foi um dos eventos mais comentados no primeiro semestre de 2015, pois uma transexual 'crucificada' encenou o sofrimento de Jesus. Márcia X. não encenou tal sofrimento, mas elaborou um novo e polêmico significado ao ato de rezar com sua exposição - Desenhando com $\operatorname{terços}^{55}$.

\footnotetext{
${ }^{54} \mathrm{O}$ conceito de utopia é vasto, porém, me apoio no proposto por Foucault, M. O corpo utópico, p 08 .

${ }^{55}$ Os terços são artigos religiosos que nos ajudam a contemplar os mistérios da vida Cristo em oração. Cada terço é formado por 58 contas, uma medalha e uma cruz ligados entre si, e representam as orações e os mistérios que devem ser contemplados.

http://www.blogcruzterrasanta.com.br/artigos-religiosos-tercos-e-rosarios/
} 
O final do século XIX e o século XX são importantes no enfrentamento de novos comportamentos ou na explicitação de comportamentos que existiam em pequenos circuitos - o artista, o nobre mais liberal que pode ser visto no filme $A$ Vênus $\mathrm{Negra}^{56}$, nas poesias de Charles Baudelaire, ou em toda teoria apresentada por Peter Gay em Modernismo: o fascínio da heresia: de Baudelaire a Beckett e mais um pоисо. Os novos comportamentos ou deixar-se ver foi algo pulsante que interferiu também na arquitetura, na moda (vestimenta), nos rituais de assepsia do corpo: a depilação, a criação do papel higiênico, a comercialização de desodorante e absorvente.

Apesar de grandes avanços e tentativas de debates com o surgimento de teorias, ainda existem posicionamentos radicais em torno de uma arte que aborda a sexualidade além dos imperativos da reprodução, pois acredita ainda na formação de um corpo imposto pela instituição da Religião - o corpo protegido pelas vestes da graça, em perspectiva agambiana ${ }^{57}$.

Diferente do corpo que possui o título de sujo, que pode ser atacado, afetado na alma ou no espírito ${ }^{58}$, o ato de rezar, orar é um momento considerado íntimo, introspectivo em muitas doutrinas religiosas. A fé, o entendimento do eu, o encontro com sua crença, o entre-lugar ${ }^{59}$. Márcia cria um espaço, um novo corpo que possui atravessamentos; porém. nesse objeto, a linguagem vai se torcer sobre si e agir, mas não através de uma escrita ou conceitos canônicos. A artista estabelece um jogo de poder entre o sagrado e o profano em um corpo social. De acordo com Orellana,

\footnotetext{
${ }^{56}$ Filme do mesmo diretor de Azul é a cor mais quente que foi exibido em 2011 e possui como embasamento discutir o corpo, a sexualidade, a exposição, o naturalismo e o preconceito no século XIX através da vida da bosquímana Saartjie. https://www.youtube.com/watch?v=3_P--6uis4Q

${ }^{57}$ Segundo Agamben, "a nudezpressupõe a ausência de vestes, mas não coincide com ela. A percepção da nudez está ligada a esse ato espiritual que a Sagrada Escritura define como 'abertura dos olhos'. A nudez é qualquer coisa que alguém se dá conta, enquanto a ausência de vestes passa a ser inobservada. [...] Antes da queda, o homem existia para Deus de tal maneira que o seu corpo, ainda que na ausência de qualquer veste não estava "nu". [...] O homem não estava só na luz da glória divina; estava vestido da glória de Deus”.Agamben, G. Nudez. Pp. 74 e 75.

${ }^{58}$ Não há aqui interesse de discutir as diferenças entre os verbetes alma e espírito. O que quero é apresentar o ser que habita o homem, aquilo que estabelece contato com a sua fé.

${ }^{59}$ Entre lugar é compreendido como um espaço intermediário, intersticial, de trocas e mudanças que permite sair da lógica das oposições binárias (realidade/invenção; sujeito/objeto; identidade/alteridade etc.). HomiBhabha aborda que desta forma fornece o terreno para a elaboração de subterfúgio de subjetividade, singular ou coletiva, que dão início a novos signos de paridade e postos inovadores de colaboração e contestação. O conceito é abordado e desenvolvido por SANTIAGO, S. $O$ entre lugar do discurso latino-americano. In: Uma literatura nos trópicos. Rio de Janeiro: Rocco, 2000. E por BHABHA, H.K. O local da cultura. Belo Horizonte: Ed. da UFMG, 1998. Esse conceito foi amplamente discutido e abordado nas aulas de estudos Culturais do curso de Especialização Literatura, Arte e Pensamento Contemporâneo 2012.
} 
“o poder não apenas reprime, mas também produz um modo de individualização que é aquele que nos conduz a buscar e tentar uma identidade perdida" 60 .

O homem e sua fé são colocados radicalmente em questão através de mutações de símbolos que escreveram a nossa história. A escrita com o corpo ou através do corpo é como um ensaio, são idas e vindas na composição de outra ou uma identidade,pois o sujeito pode sofrer um estranhamento das normas instituídas, das tensões conceituais de pertencimento entre os gêneros. O que também pertence a essa zona de leitura que apoia-se na construção da identidade e da noção do conceito de sujeito é a articulação da possível fronteira simbólica da sexualidade. E a sua construção vai ao encontro de um desejo que, no caso do transexual, está na contra mão de suas memórias, mas, ao encontro de sua identidade. Márcia X., através de uma arte metonímica, rompe com a tradição, subverte a utilização de um objeto religioso para também escrever com o corpo e não sobre o corpo.

A genealogia da sexualidade após as mudanças da década 60 afeta, diretamente, vários campos da arte nas décadas posteriores. Isso pôde ser visto pela produção de discursos díspares que interviram na legitimação, por exemplo, dos conceitos base dessa pesquisa: noção de corpo, erotismo e biopoder.

Muitos agenciadores de corpos, além dos já citados, apontam que a Filosofia refaz a relação de corpo e pensamento. Dessa forma, os vetores de força que balizam a sociedade sofrem desestabilizações, gerando novos conceitos que tencionam a abertura de debates sobre as mudanças de comportamento. As marcas do que pertence a uma geração ou outra receberam esse ataque, pois ao invés de percebermos como essa mudança ocorre a cada onze anos, temos a proposta de mapear uma mudança geracional a cada sete anos. Ou seja, o que se mapeava a cada onze anos, caiu para sete anos. Os conflitos de uma geração, suas marcas e empoderamentos estão mudando a cada sete anos.

O significado dessa operação talvez ocorra devido à quantidade de corpos e subjetividades que apenas deixam rastro, pois transformam-se em uma velocidade tão radical que o efêmero necessita de uma nova acepção. O que pertence a uma geração não está mais no intervalo de onze anos.

${ }^{60}$ ORELLANA, R. C. A ética da resistência, p. 39. 
Esse trabalho aborda em certa medida como essa impulsão pós geração 68 e a mudança de função social da arte chegam ao Brasil. O corpo como prática de vida, o seu moldar, a droga como um canal de experimentação do corpo, a invasão do corpo cujo contorno não está definido, o corpo como eixo primário do desequilíbrio. A vida sendo vista de outra forma e interferindo na arte que está sendo produzida e vivida.

Essa abordagem está diretamente ligada ao trabalho de alguns artistas que possuem um embate direto no confronto arte versus vida. Destaco a politização exercida por Barrio nos seus Livros: carne e de artista e suas Trouxas de Ensanguentadas. Barrio faz a mesma provocação que será vista em Cassandra e Márcia $\mathrm{X}$.

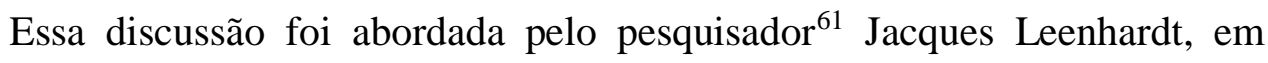
2013, aqui no Brasil. Sua proposta era uma análise temporal e crítica a partir de maio de 68. Essa releitura dos anos 60-70 ajuda na percepção de que aquela Revolução foi atuante também no Brasil e pode ser vista em outras artes além de Cassandra, que vive essa mudança (seu primeiro livro foi em 1948) e em Márcia X, a partir de 80 .

No decorrer dessa pesquisa, encontro em Barrio a prática de pensar e impulsionar novas perspectivas sobre os corpos: paradoxal, abjeto, espectro, corpo sem órgãos, corpo sutil, corpo máquina - fisiológico, orgânico, unitário - o monstro, a caricatura e a pulsão. São muitos conceitos, teorias e pesquisadores que mostram a permanência do debate do corpo como espaço de produção de novas subjetividades e não apenas como a representação da encenação de conflitos.

A explosão de/dos dispositives-que unificam o corpo. O trânsito entre os campos da cultura. Barrio amplia o meu debate crítico ou a fome de promover um debate crítico, pois trata de forma impositiva a produção de novos corpos. Além disso, demostra como os campos teóricos passam a ser tratados com uma questão política e não intelectual - legitima o apresentado por Leenhardt e corrobora outros pensamentos acerca dos corpos.

\footnotetext{
${ }^{61}$ Um convênio acadêmico em 2014 de Universidades brasileira e HESS, Paris resultou na disciplina LET 2500 no Departamento de Letras da PUC-RIO. Dessa forma, filósofo e crítico Jacques Leenhardt ministrou a disciplina "Reler os Anos 60-70: entre Estruturalismo e Pós-estruturalismo - uma Reviravolta na Cultura e na Arte?".
} 
Luiz Camillo Osório em um artigo intitulado "Entre o ver e o ler” 62 aponta que:

ao contrário do conceitualismo europeu e americano, no Brasil dos anos 70 não se tratava de incorporar a instituição, mas negála e inserir, com o máximo de atrito e faísca possível, no circuito ideológico, fora da defesa e da censura institucional. (Grifo meu)

Osório discute e investiga a forma-livro de Barrio. Destaco sua análise, pois essa arte funcionou como uma performance e o espectador penetrou na obra, mesmo a contra gosto do artista, através de seus gestos, observações e entendimento do processo.

Outra vertente do trabalho é abordar criticamente também a questão da arte como sintoma e não como forma de expressão, considerando que o valor dessa construção não reside apenas no visual, mas em como foi produzido e pensado. Logo, interessa rever esse trabalho para confrontar com o debate atual das obras de Márcia e Cassandra.

Em poucas linhas, é justamente o que faz Osório, que aponta como os livros de artista de Barrio "não se tratam de tomá-los apenas como produtos secundários, como um documento, mas tomá-los por si mesmo". Ou seja, o artista preocupado com o processo do seu trabalho e não apenas com o visual. Os corpos que Márcia X. produz também são pensados em uma dimensão mais ampla e não apenas na vendagem de um conceito ou na lotação das instituições. Assim, um conceito é retomado e outro somatizado: utopia - relacionado ao corpo/arte produzido (a); heterotopia $^{63}$ - em vinculação aos espaços escolhidos pelo artista.

Em seus livros ou em suas trouxas, a questão política se faz tão presente que chega a ser algo palpável, pois esses artefatos rompem radicalmente com o conceito tradicional de arte e a propõem novos caminhos. Talvez caminhos que não foram trilhados por outros logo após suas performances. Barrio foi intitulado como artista

\footnotetext{
${ }^{62}$ OSÓRIO, L. C. Entre o ver e o ler, p. 407.

${ }^{63}$ Em geral, a heterotopia tem como regra justapor em um lugar real vários espaços que, normalmente, seriam ou deveriam ser incompatíveis. [...] Ocorre que as heterotopias são frequentemente ligadas a recortes singulares de tempo. FOUCAULT, M. O corpo utópico, as heterotopias, pp. 24 25 .
} 
marginal; ou seria ele maldito? Pois ele alega, em entrevista a Paula Alzugaray, que o espectador não faz a obra ${ }^{64}$.

Barrio declara em entrevista ${ }^{65}$ ao jornal $O$ Globo, que

Fiz Arte Social e descobri que o meu engajamento, como o engajamento de todo artista, é perigoso para a arte. Porque quando a esquerda chega ao poder o artista vira um artista oficial. E quando percebi isso tive um choque muito grande. Ser um artista de sucesso me soou estranho e contraditório, e na Europa passei a trabalhar apenas em espaços alternativos.

A reivindicação exercida pelo corpo passa por experiências que podem ser prazerosas ou provocadoras. As atuações Barrio, Cassandra, X e Kechiche refizeram a noção e a função social do corpo. $\mathrm{O}$ homem que aceitou as transformações que aconteceram desde as Vanguardas Culturais é um sujeito senhor de sua vontade. Para Deleuze,

Não o homem como rei da criação, mas aquele que é tocado pela vida profunda de todas as formas e gêneros, o encarregado das estrelas e até dos animais que não para de ligar máquinas-órgãos a máquinas-energia, uma árvore no corpo, um seio na boca, o sol no cu: o eterno encarregado das máquinas do universo. ${ }^{66}$

Para além desses dispositivos, outras interpelações são indispensáveis: a) Como se passa a considerar o erotismo a partir da divulgação do conceito de biopoder?; b) Quais são os campos de força do erotismo para o refazimento do corpo?

Segundo Bataille,

O que está em jogo no erotismo é sempre uma dissolução das formas constituídas. Repito-o: dessas formas de vida social, regular, que fundam a ordem descontínua das individualidades definidas que somos ${ }^{67}$

Para Bataille, bem antes das sistematizações apresentadas no início da minha escrita, o erotismo é esclarecimento. Sendo assim, a maneira como o desejo

\footnotetext{
${ }^{64}$ http://p.php.uol.com.br/tropico/html/textos/1759,1.shl

${ }^{65}$ MARTINS, A. Barrio de mal com a arte social, $O$ Globo.

${ }^{66}$ DELEUZE, G. O anti-édipo. Capitalismo e esquizofrenia 1, p. 10.

${ }^{67}$ BATAILLE, G. O erotismo, pp. 42-43.
} 
circula e estabelece laços é decisivo como fator político, pois "desejar é construir um agenciamento, construir um conjunto" ${ }^{68} \mathrm{O}$ tema dessa pesquisa possui uma relação direta com o que é apresentado e debatido pelo filósofo, pois o erotismo é uma experiência que atravessa as esferas das instituições e da subjetivação. Da mesma forma, os estudos de Foucault a respeito do biopoder ajudam no esclarecimento dos tipos de intervenção política dirigidos ao comportamento dos corpos no que se refere à sexualidade. Algumas manifestações artísticas nos impõem uma leitura desse conceito a contrapelo.

Diante de tantas renovações, surgem novas experiências corporais e é possível comportamentos. Além de ser uma obra aberta e moldável, ele habita as pulsões. De acordo com Stuart Hall ${ }^{69}$ :

\begin{abstract}
O sujeito previamente vivido como tendo uma identidade única e estável está se tornando fragmentado, composto não só de uma única, mas de várias identidades, muitas vezes contraditórias ou não resolvidas. $\mathrm{O}$ processo de identificação, através do qual projetamos nossas identidades culturais, tornou-se provisório, variável e problemático. Esse sujeito pós-moderno, conceitualizado com não tendo uma identidade fixa, essencial ou permanente. A identidade trona-se uma celebração móvel, transformada continuamente em relação às formas pelas quais somos representados ou interpelados nos sistemas culturais que nos rodeiam.
\end{abstract}

Entretanto, ainda vivemos sob as regras das instituições que, em alguns casos, rejeita, reafirma ou ainda trata o corpo como o espaço para reprodução de ciclos fisiológicos ou químicos. Tudo conspurcando e criando uma fronteira delicada para delimitar campos da cultura através de um apelo moral: o que é belo e elevado e que se opõe ao baixo e feio - outros jogos de poder:

Se o poder se realiza por todo o corpo social, é porque a liberdade está por todas as partes e, sendo assim, sempre cabe a possibilidade de transformar as coisas. Do mesmo modo, se o poder é cada vez mais elaborado e complexo em seu exercício, e penetra criando desejo, provocando o prazer, produzindo o saber, será preciso surpreendê-lo neste trabalho com os comportamentos e o corpo. É necessário estabelecer qual o papel a ser jogado

\footnotetext{
${ }^{68}$ DELEUZE. G. Abecedário de Gilles Deleuze. Disponível em: www.filoczar.com.br/.../O\%20ABECEDÁRIO\%20DE\%20GILLES\%20D.

${ }^{69}$ Hall, S. A identidade cultural na pós-modernidade, pp. 12-13.
} 
pela liberdade, identificar o que resiste a um sistema de sujeição específico ${ }^{70}$.

A revolução sexual no Brasil acontece no momento de um golpe político. Desta forma, o erotismo tão discutido por Foucault na história da sexualidade como parte integrante de nossa educação pastoral começa a atuar de forma política e adentrar nas performances, nas instalações, nas artes, na literatura. A escolha de Marcia X. e Cassandra Rios, no contexto cultural a partir de 70, deveu-se aos modos de interferência social das artistas como "dispositivo" de resistência ao estabelecimento de diferenciações fechadas, explorando assim os aspectos do comportamento sexual/erótico na fixação de identidades.

Essa pesquisa considera que na busca da identidade o processo de diferenciação é estabelecido pelos campos de forças que são impostos por alguns vetores como: a demarcação de fronteiras, a classificação, as normatizações, os pertencimentos. São nesses vetores que atuam as relações de poder.

As práticas artísticas destacadas para o objeto de estudo funcionam como suporte político, constituindo um espaço de experimentação em que se questionam os controles sociais que incidem sobre a força revolucionária do desejo. Esses embates são um campo fértil na produção de subjetividades em torno do sexo.

Fazendo uma apropriação do discurso de Foucault, destaco que a sexualidade ainda produz corpos e identidades através de um discurso social que possui uma regulamentação tal como a ciência. A observação se apoia no entendimento, como já citado, de que veiculamos o sexo e o corpo às leis dos ciclos químicos e fisiológicos. Acredito que por esse motivo há uma rejeição, uma negação da possibilidade de se falar sobre sexualidade através das artes plásticas e da literatura. Os artistas que transpuseram a barreira da ciência - tanto quanto da moral e da religião - foram afetados por esses posicionamentos radicais e por rotulações indevidas. A transposição é dada pelo uso de termos que possuem uma variação de acordo com a ideologia de cada época e com suposta profanação de símbolos que são considerados sagrados.

A tentativa por meio de um desejo de encarnar um corpo no outro, uma arte no corpo, o corpo na arte. De despojar um corpo pelos movimentos e elaboração de uma escrita artística que se finaliza no contato com o outro.

\footnotetext{
${ }^{70}$ ORELLANA, R. C. A ética da resistência, p. 44.
} 
A construção do texto com seus suportes apresenta seu ponto de partida. $\mathrm{O}$ cenário tradicional da escrita era composto de tinta e tela, depois folha e caneta, campo semântico polido, valores burgueses. As propostas de Artaud, Bataille e Foucault reconstroem a noção de corpo e a linguagem atuante dessa noção. Uma nova era com

\begin{abstract}
"uma nova sensibilidade cultural, uma ética e uma estética política cujas implicações rapidamente transbordam as fronteiras de seus fóruns iniciais e passaram da área jurídica para estruturar a maneira que entendemos e representamos conflitos culturais, seja na mídia, nos debates políticos, na literatura, no cinema ou nas artes" (SCHØLLHAMMER apud KEENAN \& WEIZMAN ${ }^{71}$ ).
\end{abstract}

Ampliamos o olhar e abrimos a mente para entendermos que os novos cenários da escrita são, na contemporaneidade, corpo, vazio, cor, roupas, restos, dejetos, gestos, cicatrizes, marcas, som, fazer amor e politizar a sexualidade.

\footnotetext{
${ }^{71}$ OLINTO, H. K \& SCHOLLHAMMER, K. E. (orgs.). Cenário contemporâneo da escrita, p. 99.
} 


\title{
3- Seja Safo de Perdizes seja herói
}

\begin{abstract}
A transgressão não está, portanto, para o limite como o negro para o branco; o proibido para o permitido; o exterior para o interior; o excluído para o espaço protegido da morada. Ela está mais ligada a ele por uma relação em espiral que nenhuma simples infração pode extinguir. Talvez alguma coisa como o relâmpago na noite que, desde tempos imemoriais, oferece um ser denso e negro ao que ela nega, o ilumina por dentro e de alto a baixo, deve-lhe, entretanto, sua viva claridade, sua singularidade dilacerante e ereta, perde-se no espaço que ela assinala com sua soberania e por fim se cala, tendo dado um nome ao obscuro $^{72}$.
\end{abstract}

Foucault

Transgredir comportamentos impostos através do sexo entre mulheres, do forjamento do corpo de um travesti e do desejo sexual que pulsa no corpo de uma criança. Essas três imagens possuem um acionamento na escrita de Cassandra Rios que começa sua trajetória em 1948. Cassandra acompanha com sua escrita e seu corpo todas as mudanças da instauração dos conceitos que são fundamentais para as revoluções culturais em diversos campos da cultura brasileira a partir da década de 60.

O desejar. A vontade. Esse momento da pesquisa entende os três movimentos do desejo que são trabalhados por Suely Rolnik como fundamentais para explorar Cassandra Rios. Para Suely Rolnik:

Desejo: consiste no movimento de afetos e de simulação desses afetos em certas máscaras, movimento gerado no encontro dos corpos (...) consiste também num movimento contínuo de desencantamento, no qual, ao surgirem novos afetos, efeito de novos encontros, certas máscaras tornam-se obsoletas; movimentos de quebra de feitiço; afetos que não existem e máscaras que já perderam o sentido ${ }^{73}$

A religião imprimiu na nossa cultura um olhar segregador entre os gêneros e o desejo, devido ao fato de relacionar a pornografia ao sexo e à sexualidade. Para

\footnotetext{
${ }^{72}$ FOUCAULT, M. Prefácio à transgressão, p. 33.

${ }^{73}$ ROLNIK, S. Cartografia sentimental - transformações contemporâneas do desejo, p. 36.
} 
Ramayana Souza, a justificativa do conceito de pornografia perpassa por Susan Sontag e três ordenadores:

Sontag procura ver a pornografia fora da lógica redutora que a coloca como sintoma psicológico patológico ou como mercadoria social problemática. Para a crítica estadunidense, há uma série de argumentos que são apresentados para excluir a pornografia da esfera literária: em primeiro lugar, o objetivo da pornografia, a excitação sexual, excluiria o envolvimento mais distanciado que caracteriza a literatura; além disso, a obra pornográfica não teria a preocupação de uma progressão dramática; em terceiro lugar, a pornografia não se preocupa com a expressão propriamente dita - a linguagem "literária"; por fim, a pornografia tenderia à despersonalização e à falta de complexidade na construção dos personagens. $^{74}$

Em 1932 nasce uma "heroína" que vai contemplar e manufaturar o mundo de uma forma muito diferente do proposto até então pela ficção brasileira. A escrita de Cassandra vai ao encontro das teorias apresentadas pelo pensamento de Artaud e aborda os devires minoritários. A utilização do verbete heroína se deve a sua postura de resistência das inúmeras tentativas de boicote a sua literatura, considerada obscena e menor.

Cassiano Quilici estudou o texto Para acabar com o julgamento de Deus, de Artaud, e chega à premissa de que "a transformação física do homem deverá passar necessariamente pela redescoberta e pelo redirecionamento de seus apetites ” 75 . Partindo desse pressuposto, é urgente a revisão das instituições doutrinárias que sustentam a sociedade: Estado, Igreja e Família. Cassandra Rios, através de sua literatura, nos convoca a uma crítica aos padrões impostos à sociedade brasileira.

Os corpos do prazer, desenvolvidos por Cassandra, operam trocas por um chamamento. Para Jean-Luc Nancy, o corpo do prazer é "liberado de seus esquemas perceptivos e operatórios, que não mais dá a ver nem sentir em geral, segundo as modalidades de uma vida funcional, ativa ou relacional ${ }^{76}$ ". Se, como vimos, Estado, Igreja e Família descartam o corpo do prazer, como encontrar zonas de contato entre o sexo, a religião e o corpo? É difícil encontrar zonas de contato entre o sexo, a religião e o corpo. Nas narrativas de Cassandra, encontro um rastro dessa zona de contato. As estruturas das narrativas construídas por Cassandra não só trabalham

\footnotetext{
${ }^{74}$ SOUSA, R. L. Meta(na)morfoses Lésbicas em Cassandra Rios, p. 129-141.

${ }^{75}$ Quilici, C. AntoninArtaud e os Destinos dos Apetites, pp. 67-75.

${ }^{76}$ NANCY, J.L. Corpo, fora, p. 25.
} 
com os corpos do prazer como também desarticulam alguns vetores referentes ao Estado, à Família e à Religião.

Diferente de Márcia X., Cassandra não provoca diretamente o Cristianismo, mas desarticula comportamentos, aponta tendências e dá nome ao obscuro. No Livro Eu sou uma lésbica, a autora lembra um comportamento tão comum no carnaval: a troca de gêneros. A explicitação de algo que pode estar no íntimo do ser. Aquele segredo que, devido às marcas da nossa cultura, impedem ou violentam quem deseja transgredir.

Uso novamente o texto de Quilici, pois o autor acredita que "Artaud considerava a vida sexual moderna como um mecanismo de restrição da experiência do homem". Quando a modernidade chega à sexualidade, a questão sobre os gêneros sofre uma crítica. Na sociedade brasileira, cada gênero possui uma inscrição determinada em diversos campos da cultura. A questão é ampla e começa a ser desenvolvida pela religião, uma vez que no Brasil as religiões cultuam deuses ou um único Deus. Dessa forma, é evidente a marca que o gênero masculino possui. A relação entre gênero, corpo e religião pode ser apresentada ou debatida a partir, não somente, do processo de cristandade.

O debate a que me proponho não é um elencar das obras de Cassandra e sim a compreensão de como a ruptura no tratamento da temática sexualidade reconfigura nossas formas de agir, de desejar e julgar. Talvez esse seja o motivo dos impasses e desacertos da crítica em relação a esse gênero artístico. Os romances de Cassandra Rios, tratando em primeiro plano a temática da sexualidade, podem ser lidos como estratégias de questionamento - e eventual transformação - dessas reconfigurações.

Cassandra escreve desde 1948, porém o recorte histórico que interessa a essa pesquisa é como suas histórias eram recepcionadas e propuseram debates. Seus livros tratam da sexualidade além dos imperativos da reprodução. Isso resulta na classificação de censurado na década de 70, em que o Decreto-lei no 1077/70 é instituído. Cassandra tem 36 livros censurados pela $\mathrm{DCDP}^{77}$, assim como outros livros e revistas que desrespeitavam os limites impostos.

\footnotetext{
77 Órgão responsável pela censura de produções artísticas durante o regime militar, a Divisão de Censura de Diversões Públicas (DCDP), tem sua gênese em um decreto de 1934, com o qual Getúlio Vargas criou o Departamento de Propaganda e Difusão Cultural. Em 1939, surge um outro braço de sua inspiração: o Departamento de Imprensa e Propaganda (DIP).

http://www.censuramusical.com.br/historia.php?include $=\mathrm{h}$
} 
A referência a Safo de Perdizes na indicação desse bloco reporta-se ao título do documentário sobre a vida de Cassandra Rios, considerada uma Safo local. Esse epíteto refere-se ao fato de que, em princípio, os romances de Cassandra destinavam-se ao público feminino. Sendo assim, um amplo debate em torno das perversões é rememorado nesse período. Por esse motivo o tratamento dado a esse bloco deverá contar com as proposições sobre gênero, uma vez que essa abordagem se faz necessária para o confronto com as condenações, excessos e equívocos da época.

Como se percebe no documentário referido, os romances de Cassandra desencadeavam questões complexas: a não aceitação pela crítica, a estigmatização pelo público a que as histórias se dirigiam, a suposta obscenidade da linguagem, as punições da ditadura. Tudo isso contribuiu para a posição marginal em que a autora foi lançada, num contraste evidente com o fato de ter sido a primeira brasileira a chegar à marca de um milhão de livros vendidos em 1970.

Tal circunstância sugere a aproximação do caso de Cassandra à proposta de Hélio Oiticica em abordar a marginalidade vivida por ele nos tempos em que frequentava o morro da Mangueira. A determinação do artista Hélio Oiticica era a de reverter o julgamento social, rememorando a marginalidade com a frase: "Hoje sou marginal ao marginal, marginal mesmo: à margem de tudo, o que me dá surpreendente liberdade de ação" ${ }^{\prime 78}$ e com a bandeira onde se lia: "Seja marginal/ seja herói". Desta forma, proponho uma mudança decisiva da perspectiva de leitura dos romances de Cassandra a partir da também reversão de julgamento social. Cassandra não apenas fala do sujo, do gueto ou do proibido. A autora amplia os debates sobre corpos e suas sexualidades.

O julgamento social faz com que Cassandra ocupe um espaço na literatura brasileira pela margem, por um espaço de passagem: a banca de Jornal, levada pelas mãos de jovens que colocaram sua escrita em destaque, seja por curiosidade, seja por fetiche.

O primeiro contato com a figura de Cassandra veio não apenas pela questão da marginalidade, como também pelo argumento de que esse tipo de escrita deveria

http://acervo.oglobo.globo.com/em-destaque/nos-anos-70-ninguem-foi-mais-censurado-no-brasildo-que-cassandra-rios-10425009

${ }^{78}$ Frase de Hélio Oiticica em resposta a carta de Lygia Clark datada em 15 de outubro de 68. 
ser considerado baixa literatura. Como justificar que uma escritora de baixa literatura conseguiu vender 1 milhão de livros com a ajuda das bancas?

Escolho a narrativa ${ }^{79}$, Uma mulher diferente, para iniciar a escrita sobre corpo e sexualidade em Cassandra, por entender que esse debate é o mais contemporâneo. Na época do lançamento do livro de Cassandra, ser um travesti ocorria em espaços específicos. Em 2015/2016 é comum a exibição de corpos transformados por cirurgias ou roupas. Sua protagonista, Ana Maria, que está morta no início do romance, traz para os olhos da sociedade cega aquilo que só deveria existir na zona de tolerância. Outra questão que vem pela história de Ana Maria é que quando os corpos marcados pelo HIV começam a ter visibilidade, são estereotipados, já que estritamente relacionados a tipos sociais como Ana Maria. Curiosamente, o conjunto de inúmeras Anas é chamado de grupo de risco.

Na contemporaneidade, a transformação sofrida pelo corpo de um transexual ou travesti pode ser, e é, explorada em livros, blogs, diários virtuais. Esses suportes registram sua transformação como uma metalinguagem: o corpo que trata da transformação do corpo. A exibição das cicatrizes que comemoram a mudança de gênero. A polimorfia do corpo como bandeira que marca os novos debates sobre a questão de gênero.

No contexto histórico de Cassandra, a questão era outra:

Durante os anos 60 e 70, a proliferação de regimes militares e fascistas por toda América Latina precipitou uma crise na representação engendrada por práticas discursivas unívocas e autoritárias. Através do reforço de rígidos processos de censura, o diá$\log$ foi eliminado ou deslocado para o underground ${ }^{80}$.

Assim, sua escrita possuía outras zonas de contato - de divulgação.

A escrita de Cassandra sobre o travesti Ana Maria e o uso de seu corpo como o antídoto que cura as dores dos homens mais viris da sociedade na época atravessa a linguagem literária para transgredir os códigos. Para Octavio Paz, a literatura possui um caráter transgressivo. Destaco o fragmento:

Uma linguagem que corte o fôlego. Rasante, talhante, cortante. Um exército de espadas. Uma linguagem de aços exatos, de relâmpagos afiados, de esdrúxulas e agudos, incansáveis, reluzen-

\footnotetext{
${ }^{79}$ Essa dissertação não irá analisar a estrutura da narrativa de Cassandra Rios.

${ }^{80}$ SANTOS, R. J. Cassandra Rios e o surgimento da literatura gay e lésbica no Brasil, p. 17.
} 
tes, metódicas navalhas. Uma linguagem guilhotina. Uma dentadura trituradora, que faça uma pasta dos eutuêlenósvósêles. Um vento de punhais que desgarre e desarraigue e descoalhe e desonre as famílias, os templos, as bibliotecas, os cárceres, os bordeis, os colégios, os manicômios, as fábricas, as academias, os pretórios, os bancos, as amizades, as tabernas, a esperança, a revolução, a caridade, a justiça, as crenças, os erros, as verdades, a verdade $^{81}$.

Na narrativa de Cassandra sobre um travesti, cabe destacar a primeira página e a descrição do detetive Grandão: “(...) era um detetive de raciocínio rápido e também de gestos ágeis de pugilista profissional. Sua aparência física - máscula, hercúlea, quase brutal - é que motivara aquele apelido" ${ }^{\text {}}$. Essa passagem contrapõe-se com que é apresentado sobre a "vedetinha" Ana Maria, pois ela era confundida com uma mulher, de acordo com o livro. Insisto nessa questão, pois ao longo da trajetória de Grandão, ele encontra com diversos homens viris, másculos que se renderam ao prazer que o corpo de Ana Maria produzia. Essas personagens, em sua maioria, perdiam a referência quando descobriam a identidade de nascimento de Ana Maria - alguns agiam de forma culposa, outros eram tomados pelo ódio - mas em todos os casos os corpos dos homens reclamavam o prazer que sentiram com a vedetinha.

Não entendo que a escolha de Cassandra seja para marcar o falocentrismo. Entretanto, a postura e o porte de Grandão são os fatores que garantirão a resolução do crime. Se, na pós-modernidade, a brutalidade da morte de um travesti ${ }^{83}$ é desconsiderada, sendo tratada como mais um crime, no livro de Cassandra o crime e sua resolução ainda são considerados acontecimentos importantes.

Um ser que não se reconhece e precisa transformar-se em outro. Uma reflexão sobre o curso de um devir-minoritário - assim Cassandra legitima através da concretude textual e literária uma possível estratégia de existência de um feminino imprevisto, estrangeiro em corpo masculino normalizado.

Assim como Ana Maria, tantas outras pessoas não dão conta do gênero de nascimento. Entendo que o debate sobre isso é amplo, que está sendo construído e necessita de muitos outros debates, porém estou utilizando gênero como uma marca

\footnotetext{
${ }^{81}$ PAZ, O. Signos em rotação, p. 312.

${ }^{82}$ Rios, C. Uma mulher diferente, p. 7.

83 A nomenclatura que Cassandra usou em 80 teve inúmeras torções: Cisgenero, Cissexismo, Crossdresser, Drag Queen e Drag King, Intersexual, NB, Pansexual, Queer, Transgênero.
} 
de macho versus fêmea. Entretanto, o que interessa é a vontade, o desejo da mudança. O que ele/ela guardou primeiro em seu arquivo pode ser o desejo de vestir uma roupa feminina; a vontade de possuir uma mama; o horror em ver sua forma refletida no espelho. Dessa forma, o corpo de Ana Maria, a busca de sua sexualidade, suas memórias vão necessitar de teorias e conceitos. No caso do corpo abordado por Cassandra - um corpo estranho estrangeiro - necessito do conceito de arquivo.

O conceito de arquivo, segundo Diana Klinger em seu artigo intitulado Paixão do arquivo ${ }^{84}$, explicita que, “O vocábulo arquivo [...] coordena dois princípios: o da natureza, ou da história, ali onde as coisas começam, e o da lei, ali onde as coisas comandam. [...] Assim, a morada dos arcontes marca a passagem do privado ao público". A memória ${ }^{85}$ permeia a construção da identidade individual e coletiva. Porém, como essa inscrição se processa em um corpo cuja morada representa a sua própria prisão?

Arrisco a dizer que a memória é outra e que, assim como Diana acredita, essa memória outra esbarra no termo pulsão ${ }^{86}$, cujo arquivamento traz a necessidade de remodelar a forma estabelecida pelas normas de gênero que compõem a base da sociedade tradicional: meninas brincam de boneca e sua cor é a rosa; meninos só podem brincar de bola e carrinho e sua cor é a azul.

Continuo com Diana Klinger. De acordo com ela, a segunda tese em relação ao conceito de arquivo, de acordo Derrida, é a pulsão da morte, de agressão e destruição. Por isso esse corpo é considerado um campo de conflitos. Além de ser uma obra aberta e moldável, ele habita a pulsão de morte no campo do arquivo e a pulsão de autoafirmação, expressa pela sua própria mudança da imagem.

O corpo anormal. Em muitos casos o corpo que opera essas mudanças acerca dos gêneros é considerado pelos tradicionais e alguns militantes do GLBT como o estranho, o anormal; o espaço determinado para o sexo monstruoso acontecer; a resistência àquilo que existe para torná-lo normal. Sua narratividade aborda uma

\footnotetext{
${ }^{84}$ KLINGER, D.Paixão do arquivo, pp. 170-175

${ }^{85}$ Para Diana Klinger o arquivo é o desfalecimento da memória.

${ }^{86}$ Por pulsão podemos entender, a princípio, apenas o representante psíquico de uma fonte somática interna de estimulação que flui continuamente, para diferenciá-la de estímulo, que é produzido por excitações isoladas vindas de fora. [...] a pulsão não tem um comportamento pré-formado e não implica um objeto específico. Ou seja, é exatamente a variação quanto ao objetivo e ao objeto que vai construir num dos pontos centrais da teoria pulsional. (LAPLANCHE, J. \& PONTALIS. Vocabulário de Psicanálise, p. 394, grifo meu)
} 
luta a favor do desejo e seus enredos como espaço de resistência às normatizações. Preciado $^{87}$ afirma:

O corpo não é um dado passivo sobre o qual age o biopoder, mas antes a potência mesma que torna possível a incorporação prostética dos gêneros. A sexopolítica torna-se não somente um lugar de poder, mas, sobretudo, o espaço de uma criação na qual se sucedem e se justapõem os movimentos feministas, homossexuais, transexuais, intersexuais, transgêneros, chicanas, pós-coloniais... as minorias sexuais tornam-se multidões. O monstro sexual que tem por nome multidão torna-se queer.

O escrever para guardar as memórias ou fragmentá-las necessita de um suporte e de uma linguagem, que pode ser uma tela, um papel, um espaço ou o próprio corpo e também uma escolha: verbal, plástica, performática etc. Escrever com a própria pele, construir memórias que não foram vividas, mas que foram impulsionadas por um desejo.

A forma como nos relacionamos com o mundo e com as criações da humanidade varia de acordo com a nossa própria existência. O registro dessa experiência fica gravado no nosso corpo, que marca e imprime todo conhecimento.

$\mathrm{Na}$ contemporaneidade, o valor dado à estrutura e formação de um corpo ultrapassa os limites da estética, pois performances e plasticidades corporais são produzidas em larga escala. Esse processo não começou ou foi sedimentado gratuitamente, uma vez que uma multiplicidade de comportamentos foi gerada através de imposições religiosas, políticas e sociais.

Após algumas leituras no campo dos Estudos Culturais, há o entendimento de que o 'eu' somente existe a partir da concepção que se faz daquele que é o 'outro'. Sendo assim, somente na relação com o outro é que o 'ser' pode se definir. Isso é chamado de alteridade e é a condição de ser o outro, mas numa esfera cambiante; face a face com o 'outro', o ser passa a perceber a sua própria face. Nas mãos de Cassandra, a construção do eu, do outro apresenta-se na estrutura da narrativa. Essa percepção e admiração transformou-se em literatura que. para Octávio Paz ${ }^{88}$,

Para nós o valor de uma obra reside em sua novidade: invenção de formas ou combinação das antigas de uma maneira insólita, descoberta de mundos desconhecidos ou exploração de zonas ignoradas nos conhecidos. (Grifo meu).

\footnotetext{
${ }^{87}$ PRECIADO. B.Multitudesqueer: Notas para una política de los "anormales",pp. 11-20.

${ }^{88}$ PAZ, O. Signos em rotação, pág. 133
} 
O corpo se oferece como prova das vivências e logo é afetado pelas palavras que saem do papel para ganharem força. A construção do eu com o referencial no outro se renova, pois se reconstrói no entre-lugar.

A criação desse corpo é uma performance e é utópica. Uma escrita possui a marca dos atravessamentos e, nesse objeto, a linguagem vai se torcer sobre si e agir, mas não através de uma escrita canônica. $\mathrm{O}$ homem se coloca radicalmente em questão através de suas mutações que vão escrevendo sua história e construindo uma memória oriunda de uma vontade capaz de monumentalizar um desejo e apagar sua identidade biológica.

A escritura desse corpo é a destruição de um sexo biológico e durante sua transformação apresenta a aparição de um corpo monstro ${ }^{89}$, pois nenhum signo vai dar conta dele. Stuart Hall ${ }^{90}$ afirma que,

\begin{abstract}
O sujeito assume identidades diferentes em diferentes momentos, identidades que não unificam ao redor de um eu coerente. Dentro de nós há identidades contraditórias, empurrando em diferentes direções, de tal modo que nossas identidades estão sendo continuamente deslocadas. [...] A identidade plenamente unificada, completa, segura e coerente é uma fantasia.
\end{abstract}

A identidade de Ana Maria vem à tona no romance à medida que as memórias das personagens que fizeram parte de sua trajetória são retomadas por Grandão. Muitas personagens não se apresentam de forma linear: Seu Antônio, o homem másculo comerciante que mesmo após saber sobre a verdadeira face de Ana Maria não resiste afetiva e sexualmente; Dr. Barbosa e sua tentativa de transformar Ana Maria em dependente química e assim viver a clandestinidade dos dois; o leiteiro que anda no despertar do dia e flertava com Ana Maria sem saber de sua transformação. A mudança que não queria ser explicitada - o conflito do eu com o outro.

O termo em alemão triebsignifica aquilo que se quer exteriorizar ou interiorizar e pode se apresentar na esfera da necessidade fisiológica ou da necessidade psíquica (desejo). Cassandra Rios construiu sua narrativa e apresentou fantasmas,

${ }^{89}$ GIL, J. O mostro e a caricatura. p. 48.

${ }^{90} \mathrm{HALL}, \mathrm{S}$. A identidade cultural na pós-modernidade, p. 13. 
espectros, confissões. Usou uma temática considerada obscena, escatológica, proibida, do gueto para abordar um comportamento marginal - no sentido de viver para além da margem da sociedade tradicional. A história apresenta os atravessamentos referidos anteriormente: seja a não aceitação do seu sexo biológico, a tentativa de encontrar sua referência, sejam as mudanças epistemológicas ou as pulsões sem uma origem justificável.

Para Andreas Huyssen vivemos uma cultura da memória e escrever a própria história com marcas no corpo é um processo violento e público, uma vez que a imagem será outra. Essa remodelagem questiona o termo íntimo - aquilo que possui um grau de privacidade muito alto e se mostra no intervalo da comunicação.

A comunicação é direta, em razão de a escrita ser com ou na própria pele. Mostrar para o mundo sua verdadeira essência é algo que sai do armário de uma forma impositiva, devido ao uso de vestimentas não impostas ao gênero biológico - uso de hormônios, aplicação de silicone, implante de cabelos etc. Há uma necessidade urgente de que esse indivíduo não adoeça, pois não viver de acordo com sua ideologia fere toda a relação com sua cidadania substantiva. Huyssen relaciona o conceito de memória aos direitos humanos e declara que tudo depende "da força dos discursos da memória na esfera pública - no jornalismo, nos filmes, nos meios de comunicação, na literatura, nas artes, na educação e até nas pichações urbanas". Logo, essa questão é social.

$\mathrm{O}$ verbete memória abrange quatro dispositivos e relaciona-se ao tema escolhido pelo dispositivo da ativação, invenção e da rasura, pois o transexual vive uma identidade ambígua, não pertence a lugar algum. Não é algo que ele pode esconder do seu interlocutor, já que as transformações são visíveis e diárias. No caso da travesti Ana Maria, havia a possibilidade do segredo apenas quando ela não tinha relações sexuais ou não era cultuada em suas apresentações. E possui o significado do caos: ser um estrangeiro no seu próprio corpo.

Em relação à instância discursiva, temos a fragmentação do corpo e a mudança de sua forma. A existência de um sexo biológico sempre se articulou de uma forma concreta para a normalização das práticas sexuais. Porém o corpo representa uma construção social e se o indivíduo não se encaixar nesse paradigma o seu 'sexo' pode ser mudado e uma personagem pode ser revelada.

A sexualidade deve ser pensada livre de amarras, porém a sociedade é um agente que define a aceitabilidade de determinados corpos. A sociedade de maneira 
geral, mesmo que soe genericamente, acredita em uma alteridade da marginalidade que abriga qualquer forma corporal não aprovada. Suely Rolnik possui um potente discurso para essa pesquisa quando comparado à representatividade do corpo de Ana Maria na cultura brasileira:

\begin{abstract}
O Brasil me parece ter algo a dizer na questão dos gêneros. Trazemos a marca de certa facilidade para nos desfazer das figuras vigentes, e com elas das identidades e gêneros, sempre que necessário. Nossa fundação e nossa história é pontuada por mestiçagens. Habituados a nascer e renascer das misturas, somos constitutivamente híbridos; borram-se em nós desde o início as fronteiras entre figuras. Um dos movimentos do Modernismo brasileiro colheu esta marca de nossa cultura e decidiu afirmá-la positivamente, chamando-a de "Antropofagia". Estendendo esta ideia, hoje, para o campo do desejo, diríamos que antropofágico é o próprio processo de composição e hibridação das forças/fluxos, o qual acaba sempre devorando as figuras da realidade objetiva e subjetiva e, virtualmente, engendrando outras ${ }^{91}$.
\end{abstract}

Após a proposta de Rolnik, um questionamento permeia minha pesquisa e não apenas esse bloco: quais são os cenários da escrita de um corpo que se inscreve a partir da repressão da sua sexualidade - desejo, prática sexual e afetos?

Um aspecto do pensamento deleuze-guattariano em $O$ Anti-Édipofoi apresentar relações de sexo e gênero relacionadas à economia capitalista, ainda que o conceito de desejo não faça remissão somente ao desejo sexual. As normatizações e elassificaçẽes dos vetores de força estão em tensão com a produção de poder do capitalismo. A formulação abaixo que justifica o meu discurso é uma interlocução entre Deleuze e Guattari:

É preciso, em primeiro lugar, desfazermo-nos de uma hierarquia estereotipada entre uma infraestrutura opaca e superestruturas sociais e ideológicas concebidas de tal modo que recalcam as questões do sexo e da enunciação para o lado da representação, o mais afastado possível da produção. As relações de produção e as relações de reprodução participam no mesmo par das forças produtivas e das estruturas antiprodutivas. Trata-se de fazer passar o desejo para o lado da infraestrutura, para o lado da produção, enquanto se fará passar o lado da família, o eu e a pessoa para o lado da antiprodução. É o único meio de se evitar que o sexual fique definitivamente separado do econômico. ${ }^{92}$

\footnotetext{
${ }^{91}$ ROLNIK, S.Guerra dos gêneros \& guerra aos gêneros, pp. 118-123.

${ }^{92}$ DELEUZE, G. O Anti-Édipo, p. 279.
} 
É curioso notar que o corpo transformado, (re) configurado possui uma cortina que pode revelar sua origem. A encenação de um novo corpo, o forjamento de memórias, a aceitação de sua vontade - tudo pode ser traído pelo desnudamento do corpo. Diferente do texto tradicional, o corpo pode apresentar sua marca inicial que um texto auto ficcional e autobiográfico pode esconder com palavras. Que corpo é esse?

Agora o braço não é mais o braço erguido num grito de gol.

Agora o braço é uma linha, um traço, um rastro espelhado e brilhante.

E todas as figuras são assim: desenhos de luz, agrupamentos de pontos,

de partículas, um quadro de impulsos, um processamento de sinais.

E assim - dizem - recontam a vida. Agora retiram de mim a cobertura de carne, escorrem todo o sangue, afinam os ossos em fios luminosos e aí estou pelo salão, pelas casas, pelas cidades, parecida comigo. Um rascunho, uma forma nebulosa feita de luz e sombra como uma estrela. Agora eu sou uma estrela

("Trem Azul", Elis Regina ${ }^{93}, 1982$ )

$* * * * * * * * * * * * * * * * * * * * * * * * * * * * * * * * * * * * * * *$

Uma criança de sete anos e uma adolescente de 17 e suas possibilidades de aceitação. De um lado Flávia e seu amor por dona Kênia; do outro, Andrea e suas descobertas do desejo.

Destaco uma fala de Flávia:

Meus dedos burilando os bicos de meus seios. Os seios intumescidos de menina-moça, nas minhas mãos, as mãos descendo, o sentimento de culpa, de revolta. Me senti como uma negra num festival de loiras, expulsa, escorraçada. Me senti uma judia no tempo de Hitler, obrigada a andar no meio das ruas, proibida de subir pelas calçadas. Me senti dentro de uma armadura, a viseira do elmo descida, empunhando a espada para abrir caminho. Me

\footnotetext{
${ }^{93}$ http://www.mueap.com.br/eventos/gravacao-ao-vivo-do-disco-trem-azul-elis-regina
} 
senti uma mulher, não uma menina, uma lésbica, uma homossexual, uma pessoa de caráter definido, de objetivos firmes, não mais o raro criptandro crescendo entre falsas lésbicas, o vegetal sem órgãos masculinos aparentes. Para quê? Para que a protuberância, o apêndice, o pênis, a vagina, o hímen? Estava tudo na mente ${ }^{94}$.

Uma menina de sete anos que inicia o contar de sua vida pelas primeiras memórias da sexualidade - o brincar de gatinhos. Na estrutura de alguns campos da cultura brasileira, essa possibilidade ainda é tratada como algo feio, pecaminoso que não pertence a determinadas faixas etárias. As escolas não discutem sobre sexo, muitos pais ainda possuem um pensamento de que os meninos podem e devem explorar sua sexualidade enquanto suas filhas devem escondê-la.

Entenda que não há uma defesa de que crianças devem fazer sexo. O que existe, o que se faz necessário, é o olhar para um corpo que pulsa. O toque no próprio corpo começa com a busca de uma sensação. Quando Cassandra coloca Flávia, uma criança, e Andrea já adolescente, do livro As traças, para flertarem com seus desejos por outras mulheres, marca sua narrativa como catalogada para além do pornográfico. O que me move agora é a pergunta de Artaud sobre sexualidade: "Qual é o ponto negro a que a sexualidade chegou?"

A escrita de Cassandra me desloca para assuntos na contemporaneidade como a pedofilia ${ }^{95}$, a tentativa de legitimar o transtorno de gênero, a androginia, o suicídio $^{96}$, a polêmica da erotização de MC Melody ${ }^{97}$ - menina de oito anos que canta funk, assuntos que todos os dias são postados, denunciados e comentados. Não debatidos, pois em muitos momentos viramos os olhos, o rosto, desviamos o caminho, mudamos de assunto. $\mathrm{O}$ fenômeno da internet permite um tom de debate, mas não é verticalizado, pois a maioria não possui uma identidade real - a virtualidade é o que dá a coragem para a exposição de um vocabulário truculento. Um

\footnotetext{
${ }^{94}$ Rios, C. Eu sou uma lésbica, p. 72.

${ }^{95}$ http://exame.abril.com.br/brasil/noticias/pedofilos-assediam-participante-do-masterchef-pelotwitter

${ }^{96} \mathrm{http}: / /$ noticias.bol.uol.com.br/ultimas-noticias/internacional/2014/12/19/adolescente-crista-de-14anos-se-mata-por-medo-de-revelar-aos-pais-que-era-lesbica.htm

${ }^{97}$ http://extra.globo.com/noticias/brasil/mc-melody-de-8-anos-causa-polemica-pai-defende-so-porque-ela-canta-funk-15737518.html
} 
artigo publicado em 2008 trata histórica e sociologicamente da Construção Social do Conceito de Infância, que ainda está sendo tecida no Brasil, já que os debates em relação aos processos infantis são pulsantes e atualizados diariamente. O campo semântico dessa construção é vasto e ganha cada vez mais volume nos estudos universitários. Para as autoras do artigo:

Os estudos sobre a infância, na atualidade, vêm se organizando em uma perspectiva de estudo, designada 'Sociologia da infância'. A Sociologia da infância, embora muito recente em termos de produção e de constituição enquanto área de estudos e pesquisas iniciou-se na França e na Inglaterra, através dos estudos de Serrota (2001) e Montandon (2001), respectivamente. ${ }^{98}$

É interessante notar que as protagonistas não ficam confinadas na infância, pois não são utilizadas como um modelo do que precisa ser disciplinado, castrado. Existe uma evolução temporal, "uma mente criando sentido, buscando sentido, preservando sentido e usando sentido; numa palavra - construtora do mundo" 99 . Mesmo com uma temática tão proibida, não há reclusão, as histórias não são relatadas em casas de tolerância ou no gueto. O estado físico e mental é malicioso, inquieto, libidinoso. $\mathrm{O}$ corpo circula pela cidade, pelas festas - um corpo em movimento e constante evolução espacial e temporal.

As protagonistas Andréa e Flávia descrevem eroticamente os corpos de seus objetos de desejo: Berenice e Kênia, respectivamente. Dona Kênia não é considerada uma pedófila, um comportamento diferente apresentado por dona Berenice, visto que ao longo do romance existem vários apontamentos de outras amantes e o surpreendente final que Andréa escuta sua mãe confessar que vivera o mesmo tipo de relacionamento. Isso indica que dona Berenice é uma predadora.

Enquanto Andréa está envolvida em um turbilhão de emoções e usa drogas para esconder sua paixão, Flávia usa um símbolo da vivência febril da sua paixão: a sandália de dona Kênia. Cassandra escolhe um plano de ações para apresentar a legitimação do desejo:

A sandália saindo da caixa. Esfregada pelo corpo. O salto fino. $\mathrm{O}$ meu olhar lúbrico. A lembrança da luva de borracha usada por

\footnotetext{
${ }^{98}$ OLIVEIRA, V. M. F.; R. NASCIMENTO, C. T. A construção social do conceito de infância, pp. 4-18.

${ }^{99}$ GREINER, C. \& AMORIM, C. (orgs). Leituras do sexo, pág. 186.
} 
mamãe para tingir os cabelos. [...] A luva que fui buscar no armário do banheiro, uma autômata dirigida pelo sexo, por um pensamento profano, estuprador, por uma ideia conspurcante, por um desejo que me robotizava, que me magnetizava, que me conduzia. A tesoura abrindo tenazes de fogo. O dedo de borracha cortado da luva. O salto da sandália no seu simbólico desempenho. Os beijos e lambidas nas tirinhas. A saliva umedecendo a capinha fina feita de dedo de luva de borracha, que vestiu o salto da sandália que eu envolvi com os lábios, umedecendo-o. Os objetos longos simbolizando o sexo masculino. O salto da sandália. $\mathrm{O}$ passo que iria entrar na casa. A casa que era uma vagina ${ }^{100}$.

Esse trecho deixa escapar a divisão territorial entre criança e adulto. Algumas palavras remetem ao infantil como mamãe, tirinhas, capinha - enquanto o ato é associado ao adulto. $\mathrm{O}$ assunto que é proibido para crianças toma forma à medida que a protagonista vai conquistando autonomia para desvendar seu corpo.

Corpo que, no caso de Flávia, é deflorado primeiro com a língua de Rosana, sua colega de classe, e depois com um dildo por dona Berenice ${ }^{101}$. O declínio de sua estabilidade emocional ocorre na mesma medida em que seu corpo é testado pelo sexo e pelas drogas. Andrea luta em vão, dado que

\begin{abstract}
procurara explicações em leituras e não se contentara com nenhuma. Chegara a rir, como se fosse uma sumidade no estudo do visado problema do homossexualismo. Que absurdos supunham e procuravam inculcar para determinar a causa. Seguramente eram todas teorias falhas. Estava ali, com sua inteligência e raciocínio, capaz de provar que não se tratava absolutamente de nenhum distúrbio glandular ou hormonal, psicose, neurose, anomalia proveniente de traumas psicológicos, complexos ou vícios adquiridos na infância. Variante da erótica, sim, uma terceira alma, essencialmente feminina, com disposição à atração por pessoas do mesmo sexo, sem influência de nenhuma característica do sexo oposto ${ }^{102}$.
\end{abstract}

Sua leitura é uma tentativa de encontrar uma resposta para um modo de vida. Um padrão que aparece na rotina juvenil, na composição familiar: seu pai provedor e sua mãe como organizadora do lar. O final da narrativa apresenta uma mãe que

\footnotetext{
${ }^{100}$ Rios, C. Eu sou uma lésbica, pp. 57-58.

${ }^{101}$ Não considero para essa pesquisa a relação de sexual heterossexual de Andrea com Moacir como exploração de seu corpo, pois na narrativa é apresentado como algo mecânico. Sobretudo é importante destacar o abuso sexual que Andréa sofre. RIOS, C. As traças, p. 255.

${ }^{102}$ Rios, C. As traças, p. 81.
} 
também passou pelas mesmas questões, mas que sua mãe supera com o casamento, os filhos e as ocupações em manter sua família feliz.

No confronto entre Andréa e sua amante Berenice, uma classificação é apresentada:

- Somos duas traças. - disse a professora.

- Traças? Por quê? Eu não quero ser traça, prefiro ser um cogumelo branco do mato, você já viu? É tão lindo, tão branco, parece um pompom de algodão, mas é venenoso...

- Eu sou a traça, pertenço à família dos tineidas e dos tisanuros, talvez do gênero lepisma. Sou aquilo que destrói pouco a pouco, não vê o franjar das minhas asas e as unhas em forma de casco?

- Não são cascos! Prefiro que você seja uma cigarra.

- Traça. Sou traça! Tentando passar despercebida entre os outros, sinto-me como a traça que se esconde entre as costuras dos livros para, no fim, morrer esmagada entre suas páginas ${ }^{103}$.

Berenice apresenta seu comportamento transgressor, sua espera silenciosa para espreitar sua presa. Uma praga que contamina e foge do estereótipo de masculinidade, pois é apresentada como alguém atraente. Essa classificação interessa a essa pesquisa, porque da mesma forma que o corpo de um transexual pode receber o aspecto de monstro ou abjeto, o corpo de uma mulher homossexual recebe nomenclaturas agressivas associadas à masculinidade: sapatão, fancha, caminhoneira, sapata, 44 e outros tantos substantivos.

Andréa, Berenice, Rosana, Flávia, Dona Kênia tangenciam as três concepções a respeito do termo lésbica. Observe o fragmento abaixo:

A primeira é aquela que considera o lesbianismo uma luta política contra o patriarcado; algumas feministas heterossexistas encaixam-se nessa categoria. A segunda é a lésbica que se envolve em questões de mulheres, tais como aborto, estupro e violência corporal. A terceira é a mais aceita - ser lésbica significa manter relações sexuais exclusivamente com mulheres ${ }^{104}$.

Uma matéria de capa da revista Galileu, 2015, sobre gênero ilustra o tipo de luta que Cassandra tentou abordar em seus romances. Para Gabriela Loureiro e Helena Vieira, que assinam a matéria, "a identidade de gênero é pouco mais complexa

\footnotetext{
${ }^{103}$ Idem, p. 226.

${ }^{104}$ BEIRUTTI, E. B. Gays, lésbicas, transgenders: o caminho do arco-íris na cultura norte-americana, pág. 64.
} 
do que nos ensinaram: diz respeito sobre quem somos, mas é regulada por instituições sociais e por nossa necessidade de categorizar indivíduos e suas atividades ${ }^{105}$ ".

$\mathrm{Na}$ época de seus romances, algumas teorias não existiam ou não eram divulgadas. Cassandra pensa sobre os corpos e a marginalidade dos corpos antes das teorias pós-estruturalistas vigorarem.

Uma questão importante é que com a protagonista Andréa ela aborda o abuso das drogas para a sobrevivência em uma realidade. É importante salientar que a epidemia do crack e da cocaína nos Estados Unidos na década de $80^{106}$ muda os imperativos a respeito do conceito de infância - impulsiona novos vetores de força para as crianças. A questão no romance é tratada como tentativa de fuga do caos da sua realidade emocional:

\begin{abstract}
Viciada! Isso era ela. E como livrar-se? Parecia que, quanto mais se aterrorizasse, mais a atraía o vidro de pílulas. Há quanto tempo se tornara escrava daquelas cápsulas? Os dias passados mergulhavam-se em trevas, em cenas fantásticas em que ela se via rodeada por fantasmas e seres terríveis. Do inferno das sensações que a consumiam era sempre Berenice, como galho emergindo de pantanal lúgubre e nevoento ${ }^{107}$.
\end{abstract}

O uso de drogas no Brasil faz parte de uma experiência geracional. A intenção não é fazer um discurso politicamente correto sobre a legalização das drogas ou a descriminalização. A loucura como resistência ao mundo. Beatriz Preciado aborda o uso de drogas como farmacopornografia ${ }^{108}$. Contudo, Preciado aborda o uso das drogas lícitas, enquanto os movimentos das décadas de 70 e 80 fazem uso de drogas ilícitas também. Na busca da loucura poética, Hélio Oiticica produz as

\footnotetext{
${ }^{105}$ LOUREIRO, G. \& VIEIRA, H. Gênero - tudo que você sabe está errado, p. 44-50.

${ }^{106}$ http://www.cartacapital.com.br/sociedade/nao-foi-tao-diferente-assim

A década de 80 do século XX representa um marco no que se refere aos direitos da criança e do adolescente. Os Estados Unidos estão enfrentando uma guerra, nesse período, contra o tráfico de drogas, sobretudo em Miami e Nova York. Miami lutava contra a cocaína e Nova York contra o crack. A relevância do fato para essa dissertação se dá pelo levantamento de que as bases que orientam os estatutos e leis em relação a criança tiveram uma mudança a partir dessa proliferação do uso de drogas.

$\overline{107}$ Rios, C. As traças, p. 241.

108 A farmapornografia constitui, segundo a autora, um novo regime pós-industrial, global e mediático, no qual, durante sua materialização, no século XX, a psicologia, a sexologia e endocrinologia estabelecem sua autoridade material, transformando conceitos como o de psiquismo, de libido, de consciência, de feminilidade e masculinidade, heterossexualidade e homossexualidade em realidades tangíveis, em substâncias químicas, moléculas comercializáveis, corpos, biótipos humanos, em bens de troca de gestão por multinacionais farmacêuticas. (PASSOS, L. 2012) Disponível em: https://ensaiosdegenero.wordpress.com/2012/04/27/a-era-farmacopornografica/
} 
Cosmococas ${ }^{109}$ - instalações que funcionam como um programa de experimentos com cocaína, capas de discos, livros e outros suportes. A loucura foi estudada por Foucault, não a do Hélio, mas a loucura como o atravessamento da ou de uma realidade. Para Foucault,

de um lado, a loucura existe em relação à razão ou, pelo menos, em relação aos "outros" que, em sua generalidade anônima, encarregam-se de representá-la e atribuir-lhe valor de exigência; por outro lado, ela existe para a razão, na medida em que surge ao olhar de uma consciência ideal que a percebe como diferença em relação aos outros. A loucura tem uma dupla maneira de postar-se diante da razão: ela está ao mesmo tempo do outro lado e sob seu olhar. Do outro lado: a loucura é diferença imediata, negatividade pura, aquilo que se denuncia como não-ser, numa evidência irrecusável; é uma ausência total de razão, que logo se percebe como tal, sobre o fundo das estruturas do razoável. Sob o olhar da razão: a loucura é individualidade singular cujas características próprias, a conduta, a linguagem, os gestos, distinguem-se uma a uma daquilo que se pode encontrar no não-louco; em sua particularidade ela se desdobra para uma razão que não é termo de referência, mas princípio de julgamento; a loucura é então considerada em suas estruturas do racional ${ }^{110}$. (Grifo meu)

Os discursos sobre loucura dialogam com Cassandra, devido à representatividade dos anormais. Ela não apresenta algo forjado pela droga ou pela poética da relação amorosa, mas o desnudamento da alma, a construção de máscaras, dos pertencimentos, dos encontros de corpos na busca de identidades - as estratégias de formação do desejo. Essa característica relaciona-se ao terceiro movimento/linha apresentado por Rolnik: "é quando formava-se um aglomerado de máscaras, constituindo novos territórios ${ }^{111}$.

O apresentado por Cassandra, não apenas nessas narrativas, transgride comportamentos que eram considerados como corretos. As mudanças operadas são tão profundas que não apenas nos jornais, revistas e no cinema essa temática está sendo discutida e explorada. Temos outras formas de aceitação.

\footnotetext{
${ }^{109}$ Cosmococa - programa in progress: de Hélio Oiticica e Neville de Almeida inclui nove BLOCOSEXPERIMENTOS, ou BLOCO DE EXPERIENNCIAS - in COSMOCOCA, elaborados de 13 de março de 1973 a 13 de março de 1974, e identificados pela abreviatura CC, seguida de um número, marcando a sequência cronológica da sua invenção. Cada bloco se compõe de uma série de slides - fotografados no ato da brincadeira de espalhar carreiras de cocaína nas capas de discos, livros e outras superfícies - de uma trilha sonora, de textos, de uma proposta de atuação do público em um ambiente determinado e de um conjunto de fotos e pôsteres - reprodução dos slides - para serem comercializados separadamente. ( CARNEIRO, B. S., 2012) Disponível em:

http://www.forumpermanente.org/portal/painel/coletanea_ho/ho_bia_carneiro

${ }^{110}$ FOUCAULT, M. História da Loucura na Idade Clássica, p. 203.

${ }^{111}$ Rolnik, S. Cartografia sentimental - transformações contemporâneas do desejo, p. 58.
} 
Essas formas podem ser vistas na série documental Amores Livres ${ }^{112}$, exibida pelo canal GNT, que apresenta relacionamentos que a contemporaneidade ainda rejeita: Trisal; Rede Relações Livres; Poliamor; Casamento A Três; CasamentoAberto; Poliamorista; Poliafetividade; Morando A Três; Amores Múltiplos; Swing. Sujeitos que não seguem padrões ou nomenclaturas, com exceção dos casais que praticam swing e do casamento a três - ou seja, não são heterossexuais, homossexuais ou monogâmicos - são seres desejantes. O termo sexo é tratado a partir de sensações, uma linguagem crua na urgência de dar conta do aqui e agora do corpo.

Outras formas de aceitação.

O campo semântico desse tipo de relação ainda necessita de explicações para não cair na banalidade. Todos os entrevistados falam de respeito de relação, de paixão, de liberdade, do sentimento: amor pleno. O episódio "Casamento A Três" dá o tom de seriedade desse tipo de relação. Em Belo Horizonte Ká, Eustáquio e Ritoca. Professor universitário que possui um casamento a três. Casamento que não vive na marginalidade, pois possui todas as relações sociais: festas, filho (Yago), papel que determina a relação - Escritura Pública Declaratória de União Estável Poliafetiva, casa, contas etc.

A partir de 1948, Cassandra transgrediu com sua literatura para mostrar que o código já era outro. Código que merece ser respeitado; que precisa de estudo; que faz parte do que entendemos como sociedade; que a ciência não consegue comprovar como anormal, mas que diversos códigos outros atacam, marcam, violentam. Dentro dessas questões levantadas pela escrita de Cassandra, a violência faz parte de todos os processos. Violência que é contestada pelo poeta quando ele canta que "consideramos justas toda forma de amor".

A escolha de Cassandra como um dos objetos para essa pesquisa - uma escrita sobre corpos e sexualidades - veio pela leitura generosa de Marília Rotear ao meu projeto. Estava certa das teorias, porém o primeiro objeto que escolhi não cabia na escrita de uma dissertação - 25 gravuras de Pablo Picasso tratando explicitamente o sexo. Eu precisaria de mais tempo para pesquisar e desenvolver.

Marco esse momento da minha trajetória, pois muitos fluxos ainda pulsam sobre esses corpos, sobre sexualidade, a busca do prazer, as transgressões. Após

\footnotetext{
${ }^{112}$ http://globosatplay.globo.com/gnt/v/4419489/
} 
leituras e pensamentos sobre Cassandra e sua escrita, sobre corpos teóricos e agenciadores, fica a sensação de que na contemporaneidade a sexualidade não refaz o corpo, apenas expõe um corpo. Não refaz, pois não se é permitido. Existe uma lista interminável de artistas, jovens, aspirantes a famosos que usam a nudez ou a sexualidade para a promoção somente do corpo orgânico. Escolho a palavra sensação não como uma questão exclusivamente sensorial, mas como conhecimento imediato da questão que tratei nesse bloco.

Ler cada página de Cassandra foi fundamental para produzir um pensamento crítico sobre a aplicabilidade do conceito de biopoder em uma literatura desvalorizada. O bloco sobre Cassandra não termina com uma síntese dos argumentos que apresentei aqui. O término é da minha escrita nesse bloco, porque essa temática cresce continuadamente a cada vez que uma menina decide tirar a roupa em uma apresentação, a cada espetáculo que homens estão purpurinados ou de sapatos de salto. Não somente nas questões artísticas, mas, sobretudo, a cada nova marca produzida nos diversos campos da cultura brasileira.

********************************************************

\begin{abstract}
A crise da modernidade trouxe em seu bojo a necessidade de uma reavaliação dos parâmetros de humanidade. Toda uma multiplicidade de concepções outras se insurgem testando os limites do corpo - testando e afirmando a diferença entre corpos e homens.
\end{abstract}

Ericson Pires

Estudar os conceitos de Artaud, Bataille e Foucault não se limitou ao espaço acadêmico. Cada teoria estudada refletiu no meu olhar como sujeito atuante. Não existe a possibilidade de divisão estudante, mulher e profissional, pois o que pesquiso não assenta minhas questões críticas. As teorias convocam uma atualização dos corpos que tratam de uma marginalidade real, já que operaram cotidianamente enquanto me divido entre o trabalho, as aulas e minha casa. Corpos e homens, teorias e realidade, notícias e artes no confronto das novas transgressões dos corpos.

Esse texto não é polifônico, contudo as notas a seguir representam a junção das funções sociais que exerço.

Alguns estudos debatem criticamente os artistas que projetam suas artes fabricando corpos a partir de conceitos já citados anteriormente no trabalho. Contudo, 
essa emergência de discursos deixa rastros, sobras. Isso interessa a essa pesquisa, pois "se a linguagem imita os corpos, não o faz pela onomatopeia, mas pela flexão". ${ }^{113}$ Dessa forma, possibilidades como: A contracultura traduzida em corpos angustiados; Resíduo como dispositivo da marginalidade; Cultura da redenção e do trauma; A permanência do Teatro Oficina; O poder da intervenção e outros aspectos me fazem pensar em diversos rumos que esse trabalho pode ganhar. Em múltiplos e inesperados caminhos que o próprio ato de escrever, pensar, reescrever, repensar, marca a produção dos cenários de uma escrita. Inúmeros descaminhos do corpo como inserção de vida e de morte das "máquinas desejantes". O motivo, cito:

Isso funciona por toda a parte: umas vezes sem parar, outras descontinuamente. Isto respira, isto aquece, isto come. Isto caga, isto fode. Mas que asneira ter dito o isto*. O que há por toda a parte são mas é máquinas, e sem qualquer metáfora: máquinas de máquinas, com as suas ligações e conexões. Uma máquina-órgão está ligada a uma máquina-origem: uma emite o fluxo que a outra $\operatorname{corta}^{114}$.

Os corpos reais. Corpos que extrapolam a narrativa marginal. Corpos que também estão estampados na banca de jornal, porém com motivos distintos.

Ando de trem e vejo uma mulher visivelmente alterada dar um tapa em outra que estava dormindo - elas não possuíam relação. A agressora embarcou na estação da favela mais violenta do Rio de Janeiro: Tancredo Neves. Lá, o Estado não atua. A venda de drogas ocorre na estação. Não possui moral. O código é outro.

Duas vezes por semana embarco rumo a Santa Cruz para dar aula. Cruzo com pessoas que dialogam com o conceito de biopoder sem ao menos saber o que significa. Vejo jovens aprovados para Medicina, Direito, Engenharia, Psicologia, Arquitetura todos com o sonho de fazer a diferença - de fazer valer a vida.

Tantas vezes saí de Santa Cruz com a escolta do Bope - do CAVEIRÃO. Muitos me perguntam o motivo de dar aulas em Santa Cruz. A minha resposta é sempre a mesma: - Lá a mágica acontece.

${ }^{113}$ DELEUZE. G. Nietzsche e a filosofia, p.20.

${ }^{114}$ DELEUZE, G. Anti-Édipo Capitalismo E Esquizofrenia 1, P. 7 
Essa escrita é para trazer o conceito que trata de vida e de morte para sua concretude. A vida que é afetada pela violência quase de uma forma naturalizada. A marginalidade é outra.

Ana Kiffer, em “O que é preciso para se refazer o corpo?”, diz que “estamos, com Artaud, tensionados entre crueldade do fato e as reivindicações de outros e transitórios espaços possíveis para os corpos, a serem de modo sempiterno, refeito, construídos". Esses espaços possíveis sucedem debaixo de tiro a queima roupa. O refazimento quando ocorre só pode ser aproveitado sob uma vigilância constante.

Quando a violência vem para o asfalto ela age de uma forma. Entrar na violência é diferente, normalmente é preciso um preparo. Mesmo com todas essas questões a mágica acontece. Que mágica é essa? O olho no olho, o toque sincero, a pergunta verdadeira, a luta pela vida.

Falamos da guerra contra o Estado Islâmico, dos ataques na França, das meninas sequestrada, de problemas que não sofremos na carne. Pego carona na coluna de Fred Coelho para uma questão que marcou a nossa carne: "A bala que matou Eduardo de Jesus atravessa todos que pensam a vida como um direito ${ }^{115 "}$ - a vida é um direito. Mesmo que possa atuar de um jeito torto na periferia do Município do Rio de janeiro.

O código que regula esse tipo de relação que atua e se inscreve pela violência não é novidade. Corpos mutilados de uma forma invisível, pessoas abandonadas pelos direitos civis - os corvos. Corvos pela atuação zoomórfica, pois alimentamse dos restos de tudo. O restinho da droga abandonada por outro dependente que não tem a lucidez para recolher o que é seu, o resto de comida jogado no lixo ou abandonado nas mesas, o celular roubado, o dinheiro afanado. Sim, tudo em um pé de igualdade, pois se esses indivíduos soubessem o que é cidadania a conversa seria outra.

A morte já está atuando. O velório é diário. Enquanto escrevo a televisão está ligada e a notícia é sobre a morte de policiais. Homens despreparados: o código é outro - é matar ou morrer.

\footnotetext{
${ }^{115}$ http://oglobo.globo.com/cultura/complexo-15808457\#ixzz3fhjyOuVR
} 
Entro novamente na minhoca de metal, outros corpos com novas histórias. Um homem tenta entrar no vagão feminino, as mulheres gritam, o guarda que deveria estabelecer a ordem ri das mulheres, a gritaria começa. Estou tão cansada que só observo. Meu corpo não obedece. Perco a fala. Outra estação e mais uma confusão. Reflito em silêncio - a falência de um corpo, a ausência de uma voz.

O telefone vibra, portanto há uma mensagem. Alguém curtiu no Facebook algo contra um ato violento. Atrizes que são violentadas pela cor da pele. Saio de casa. Entro na sala de aula e comento o caso. Um aluno levanta o dedo e pergunta: - Você acha que o seu discurso sobre negritude cola? Fico irritada. Minha aula planejada acaba, visto que falarei das teorias de Liv Sovik, em seu livro "Aqui ninguém é branco". Falo do Neymar, do comercial na época da Copa do Mundo, das cotas, da jornalista Maria Julia Coutinho, de que ser negro ou branco não é apenas pela cor da pele. Como o Neymar não é considerado negro? Que pode esse corpo? Tudo?

Fico frustrada. A conversa não terminou, porém a aula sim e o relógio marca que devo ir para outra turma. Penso em como retomar esse debate. Nãos sei se terei tempo uma vez que preciso terminar o conteúdo programático. Deixo um corpo incompleto. Deixo o rastro do caos, pois quando saio da sala dois meninos estão em um debate acalorado. A conversa toma outro rumo.

Um novo dia. Entro no transporte alternativo. O cobrador grita o nosso destino: novamente, Santa Cruz. Por força do hábito, sem regras e leis, segura no braço de uma mulher quando a van para no ponto para entregar o dinheiro ao "despachante". A mulher grita. Como estou sentada no banco da frente, vejo toda ação. A mulher, para exercer o seu direito, fala com o despachante que aquilo está errado. Ele aponta para o presidente da cooperativa. O cobrador arregala os olhos e toda sua força bruta, seu peito estufado, seu olhar determinado de que estava certo em segurar a mulher acaba com um simples gesto do presidente. O motorista fala: - Ele não vai fazer nada, pois o dono desse carro é do Bope. O mesmo Bope que faz minha escolta vez ou outra em Santa Cruz.

O caso dessa mulher me arremessa ao grupo \#primeiroassédio. No caso que assisti, a mulher sabia dos seus direitos. Tem gente que não sabe, pois é violentada 
à luz do dia e acha isso normal. Em muitos casos nem sabe o que é violência. Fico pensando no que faria se fosse comigo. A mente vai longe.

Recordo da reportagem de São Paulo em que um assaltante defende uma mulher no metrô ${ }^{116}$. O caso é o seguinte: um homem que havia saído da prisão há dois dias resolve escolher o metrô como meio de transporte. Depois de algumas estações, percebe um comportamento estranho. O caso não é simples, pois outro homem está com o pênis exposto. Não é apenas isso! Ele está tentando esfregar o pênis em uma mulher. $\mathrm{O}$ assaltante vira agente da lei. A questão se amplia, dado que o violentador sexual era um agente da CPTM. O assaltante dá voz de prisão. Todos para delegacia. Na chegada à delegacia uma repórter pergunta para o "herói": - Qual é sua profissão. Ele responde: - Sou assaltante. Esse tipo de gente, tipo que abusa de mulher, não dura na cadeia, em virtude de não ter cadeia para esse tipo de gente.

Temos no nosso país um assaltante que age como a marca da lei. Que país é esse? Não possuo resposta para isso. Não há teoria que explique. O código é outro.

Muitos casos. Muitas histórias. Muitas viagens. Muitos símbolos.

A televisão está ligada no jornal. A notícia da vez é sobre o impeachment da Dilma. Tem gente pedindo intervenção militar. Gente que não viveu a ditadura. Vai ter manifestação, gente na rua, Black Block atuando.

A regulação dos corpos que ainda não possuem códigos. O código continua sendo outro - a Cultura do trauma. O medo tem materialidade, força, esboço: o traçante que percorre, a coronhada, o desembainhar de um símbolo opressor. Quero descobrir qual é o código, a regulação.

Mais uma memória. O projeto que participei quando adolescente, Pé na Produção, promoveu várias aulas-passeio. Uma era andar pelo Centro do Rio para fotografar. Lembro-me da sensação de olhar o centro da cidade por uma lente e não pelos olhos apressados que procuram uma determinada rua com um mapa nas mãos. Foi assim que meu corpo, bem antes do curso, começou a circular pela cidade. Nas mãos, um mapa que meu pai sempre fazia a caneta, na cabeça o pensamento de que

\footnotetext{
${ }^{116} \mathrm{http}: / /$ noticias.band.uol.com.br/brasilurgente/video/2015/04/09/15435874/ex-presidiario-detemagente-da-cptm-por-abuso-no-trem.html
} 
não poderia me perder, no olhar o pânico do centro da cidade. O Centro do Rio, espaço que foi pensado para não ser ocupado, mas hoje é um símbolo de ocupação.

Ligo para saber do meu afilhado, ele mora em S.P. - Moema, ouço sua mãe falar que quase chegou atrasada em um compromisso por causa da ocupação escolar em São Paulo. Horas depois fotos circulam nas redes sociais de meninas que enfrentam policiais pelo direito de estudar perto de casa.

MENINAS+OCUPAÇÃO+DIREITOS+EDUCAÇÃO= BIOPODER. 


\title{
4- Os Metaesquemas-corpos de X ou Os Metacorpos de X?
}

\begin{abstract}
Um corpo, corpos: não pode haver um só corpo, e o corpo traz a diferença. São forças dispostas e estendidas umas contra as outras. O "contra" (de encontro, em recontro, contraposto "de perto") é a categoria maior do corpo. Quer dizer, o jogo de diferenças. Meu corpo existe contra o tecido de suas vestes, o vapor do ar que ele respira, o brilho das luzes ou o roçagar das trevas.
\end{abstract}

Jean-Luc Nancy

A escrita desse bloco permeia o preditivo. Tal afirmação relaciona-se com o atravessamento de interpretações das obras de Márcia X.. Interpretações que foram realizadas por outros pesquisadores ou textos críticos sobre Márcia e seus gestos artísticos poéticos. A base do pensamento que desdobrei sobre Márcia não possui um cânone feminista de que a artista fala das mulheres oprimidas. X. fala do humano, das relações que ainda são tabus e das inflexões que o corpo não conseguiu alcançar.

A referência dessa minha proposta vem de uma carta que X. escreve em 23 de fevereiro de 1988. A receptora da carta é Marlene. A artista escreve:

Primeiramente gostaria de me fazer apresentar. Chamo-me Márcia X. Pinheiro, tenho 27 anos e sou artista plástica. Venho desenvolvendo meu trabalho há alguns anos, participando dos eventos culturais da cidade que rompam a limitação de interesses meramente especulativos e abram espaço para intervenções voltadas ao questionamento dos fatores estéticos, sociais e filosóficos inerentes ao fazer artístico universal, especialmente à produção brasileira. ${ }^{117}$ (Grifo meu)

Pesquisar Márcia é inquietante. Ela condensa a força de um superastro.

Nas palavras de Silviano Santiago,

o artista desdobra-se em criador e criatura. Deixando aquele na penumbra da enunciação, exibe-se a si mesmo, criatura, artifício, arte, como enunciado. Ler a criatura é ler o artista. Ler é penetrar no espaço das intenções oferecidas e das proposições camufladas. ${ }^{118}$

\footnotetext{
${ }^{117}$ Trecho retirado do catálogo da trajetória da artista Márcia X. produzido pelo MAM. O trecho citado está na página 97.

${ }^{118}$ SANTIAGO, S. Caetano Veloso enquanto superastro, p. 159.
} 
As questões apontadas por Márcia X. atravessam alguns conceitos, esgarça uma linguagem ainda em construção no Brasil: o falar das intensidades dos corpos.

O espetáculo encenado pelas instalações, performances e objetos da artista é produção, sistematização e divulgação de cultura material/imaterial - uma vez que é um devir. O mito criado pela artista narra corpos ou gestos heroicos. Heroicos no sentido de ter a coragem de desbravar publicamente suas proposições. As criaturas expostas, a política, a cultura e a questão social estão fixadas. Portanto, a imagem produzida pelos corpos pensados por X. exige de nós um tempo para vermos, contemplarmos sua criação e aceitarmos ou não suas categorias.

O comportamento da artista é paradoxal, pois ela brinca com o visível e o invisível, e, para Daniel Sibony:

Para cada um, seu corpo é seu acontecimento do ser, tão essencial que se torna metáfora do ser. É então mais que a "forma contingente" que admite sua existência necessária. É o capital ou o tesouro originário que o precede e confirma seus laços com o mundo. O corpo é para cada um uma metáfora do universo e de seus potenciais de existência. ${ }^{119}$

O corpo, a marca de X. passa por uma transmutação, pois ela muda seu nome. Tomo como referência o ensaio de Marília Rothier para iniciar esse campo da pesquisa. A potência da assinatura de uma obra. Marília aponta logo no início do seu texto:

\begin{abstract}
As datas e assinaturas, que identificam quadros e sonetos, teoremas e coreografias, conceitos e sonata, não passam de etiquetas necessárias à economia e à legitimação das ciências, das artes e da filosofia, que circulam nos respectivos veículos ${ }^{120}$
\end{abstract}

A assinatura de Márcia X., a criação de seu rastro, seu deslocamento, a distinção da socialite que possuía o mesmo nome e sobrenome. A artista opera na troca de seu sobrenome uma ruptura com a tradição. Não estaria mais associada à composição tradicional da família brasileira. Isso é fundamental para incorporar a poética desenvolvida pela sua interpretação nos objetos, instalações e performances. A necessidade de se tornar X., de deixar o Pinheiro para trás, a possibilidade de tratar o erotismo, o sexo e o corpo como uma estratégia político-cultural.

119 SIBONY, D. apud JEUDY, HP. O corpo como objeto de arte, p. 66

${ }^{120}$ ROTHIER, M. C. Entre os fantasmas do arquivo e o corpo da escrita, p. 179. 
Essa estratégia não foi iniciada por X., pois é um campo que sofre uma torção em um contexto mais amplo. Sergio Bessa destaca que,

Essa erupção do erótico na arte no início do século XX é sem dúvida uma das mais importantes estratégias político-culturais jamais realizada, e seu teor subversivo é responsável direto pela minagem do código moral vitoriano. É praticamente impossível imaginar muita da arte contemporânea. Inclusive a de Márcia X., sem o trabalho daqueles precursores, embora a controvérsia de anos recentes em tono da obra de, para citar um exemplo, Robert Mapplethorpe (ou mesmo de Kiki Smith ou David Wojnarowicz), indique que ainda existe muita resistência contra a desconstrução de mitos e tabus relacionados ao corpo. ${ }^{121}$

O destacado por Bessa representa uma potência de pensamento que é interpretado por outras artistas e que, de alguma maneira, funcionam como suporte teórico para que X. pudesse criar suas obras. Márcia X. sofre censuras, contudo suas obras entram no estatuto de Belas Artes.

Diferente de Cassandra, que se expunha sobre a proteção do estatuto ficcional dos romances, Márcia X. usava seu corpo orgânico como suporte na construção de um campo artístico. Não se tratava da exibição de beleza ou prazeres individuais, mas de uma estratégia estética para ampliar criticamente o campo da arte.

Suas performances não são panfletárias. Seu discurso sobre a sexualidade constitui uma construção de si enquanto artista. Essa percepção se dá pelo questionamento incessante das possibilidades de resistir aos poderes atuantes sobre os corpos. Para explorar esse aspecto, remeto-me à manobra experimental de X., que se apresentou nua na Feira Internacional do Livro em 1985.

A descoberta de novas posturas corporais nas performances de Márcia X, enquanto pesquisa artística, pode ser aproximada do trabalho de Hélio Oiticica, nomeado Metaesquema ${ }^{122}$, que, como diz Oiticica, “é 'esquema' (estrutura) e 'meta'

${ }^{121}$ BESSA, S. X-Rated (duas ou três coisas qu'eu sei dela). In: Revista Item-4, p. 82.

122 "Alguns artistas remobilizam as linguagens geométricas no sentido de permitir que o apreciador participe da obra de forma mais efetiva. Nesta obra, como o próprio nome define: meta - dimensão virtual de movimento, tempo e espaço; esquema - estruturas, os Metaesquemas são estruturas que parecem movimentar-se no espaço. Esse trabalho mostra o deslocamento de figuras geométricas simples dentro de um campo limitado: a superfície do papel. A isso podemos somar a observação da precisão na divisão e no espaçamento entre as figuras, mostrando que, além de transgressor e muito radical, Oiticica também era um artista extremamente rigoroso com a técnica."

Disponível em: http://www.mac.usp.br. 
(transcendência da visualização), indicando uma posição ambígua do espaço pictórico, entre o desenho e a pintura" ${ }^{" 23}$. Cabe destacar a ousadia de Márcia operando jogos de percepção com seu próprio corpo ou outros corpos como formas plásticas.

O que pretendo demonstrar é como sua obra afetava o espectador e que, por isso, merece destaque crítico e não punição. Portanto, este trabalho se constitui, através de Márcia X., como o espaço onde novos vetores, a exemplo do lúdico e da problemática do desejo de atuação dos corpos, são questionados. Considerando a obra de Márcia X. como resistência às forças opressoras, investiga, através de performances, estratégias possíveis para destituir as normatizações da sexualidade.

Para organizar minha proposta para o debate em relação ao refazimento do eorpo através da sexualidade, necessito dos ordenadores.

Em primeiro lugar, interessa debater criticamente o rastro de Márcia X., pois independente da obra, a artista evoca questões em relação à cultura popular e à crítica cultural. Corpo, sexo, desejo, sexualidade, jogo, dança sexual - a linguagem na construção de corpos, que articula o debate levantado por autores como Luiz Camillo Osório e Lorenzo Mammi sobre essas noções e o popular em alguns campos da cultura brasileira. Para Mammi, "não haveria portanto, nesse caso, uma aproximação entre tradição erudita e produção de massa, mas uma substituição da cultura de elite por produtos residuais do consumo de massa, recombinados e requalificados"124. X. utiliza essa estratégia uma vez que se apropria de produtos eróticos, brinquedos, símbolos religiosos e outros elementos constituintes da cultura de massa.

O universo conquistado por Márcia X. e sua arte foi idealizado por Hélio Oiticica. X. apodera-se do museu, dos centros culturais com seus corpos intensivos e provocativos no pensar o refazimento do corpo. O conceituado por Hélio em seus Parangolés não utiliza o mesmo caminho, visto que o artista não conseguiu colocar os corpos dos passistas da Mangueira em circulação no Museu de Arte Moderna do Rio de Janeiro.

A tentativa de Oiticica marcou a exposição “Opinião 65” e a arte brasileira, pois seus Parangolés - fruto de um pensamento experimental com a comunidade da

http://www.itaucultural.org.br/acervo_itau/corrhelio.htm

${ }^{123}$ FAVARETTO, C.F. A invenção de Hélio Oiticica, p. 52.

${ }^{124}$ MAMMI, L. Erudito/Popular, p. 187. 
Mangueira - foram proibidos de movimentar-se no museu. Logo, suas estruturas não foram reveladas, já que estar em movimento com os Parangolés foi considerado perigoso e inapropriado para o espaço. Mesmo com represálias, X. consegue entrar nesse espaço dito como reservado. Márcia sofre censuras, contudo sua obra está nos centros culturais, nos museus. A obra de Oiticica está no museu, porém a base de seu pensamento que aborda o corpo maldito não entra no espaço crítico naquele momento.

\section{1- A performance ou o happening?}
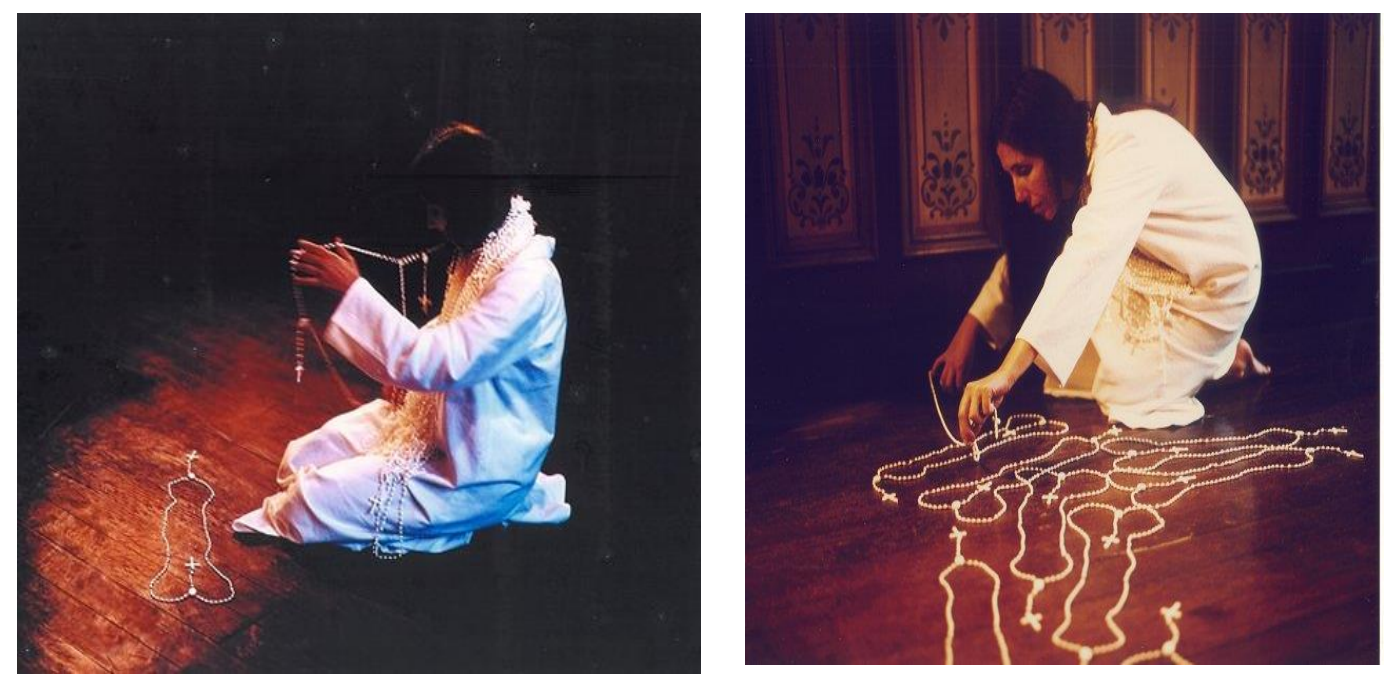

Figuras 1- Imagens da performance da artista

Desenhando com terços (2000-2003) ${ }^{125}$ foi uma performance de Márcia X. realizada de 3 a 6 horas. A questão que interessa inicialmente nessa escrita que X. faz com os terços e os pênis desenhados é o uso dos terços - um objeto religioso que trata tradicionalmente de três mistérios: Gozo, Dor e a Glória.

\footnotetext{
${ }^{125}$ As imagens da instalação de Márcia foram retiradas do site da artista. "As fotos retratam a performance / instalação realizada na Casa de Petrópolis - Instituto de Cultura (sala de jantar em processo de restauro), julho de 2000. Foram usados 500 terços (montados dois a dois). A sala mede 4 X 5m. A performance durou 6h.”. Disponível no site: http://www.marciax.art.br/mxObra.asp?sMenu=2\&sObra=26
} 
O significado do Terço: “O Terço é a terça parte do Rosário. É um conjunto de orações, de atos de amor, que fazemos meditando nos principais mistérios de nossa fé. São as rosas que, por amor, oferecemos à Mãe de Deus. "126

Após a apreensão desse significado, aposto no pressuposto de que a performance pode representar o sacrifício da sexualidade masculina como normatização. Márcia X. está de branco, em silêncio. Ela é a sacerdotisa que opera um sacrifício para a Mãe de Deus salvar a sociedade dessa dor ou, quem sabe, a sacerdotisa de um ritual pagão clamando a Grande Deusa.

O Tarot, oráculo muito utilizado no século XVIII como previsão do futuro, possui uma carta que corresponde a essa figura: a Sacerdotisa ou Papisa possui, em uma definição apressada, a mesma representatividade das sacerdotisas das religiões Afro. Os significados do Tarot foram estudados pela Psicologia. A interpretação da Papisa pode representar para essa pesquisa um grande significado elucidativo, pois Márcia X. utiliza um símbolo do Catolicismo. A imagem de um poder nas mãos de uma mulher. O questionamento que faz repensar a apreensão do mundo.

$\mathrm{Na}$ concepção que aposto, a artista não representa a fragilidade com suas roupas brancas. Ela representa a força. Sua força é tão grande que ela questiona inúmeros cânones quando faz a apropriação de um símbolo religioso para um ritual que pode ser considerado como pagão ou a transgressão da imagem do Papa em feminino.

Se X. apenas despusesse os pênis em uma sala de exibição, o debate sobre o significado do pênis poderia ser como o sugerido por Luana Tvardovskas, de que esse e outros trabalhos de X. marcam o feminino, a "evidência que a mulher assexuada, santificada e glorificada pelo imaginário ocidental agora se radicalizou." ${ }^{127}$. A questão pode se tornar muito mais ampla se considerarmos a projeção de seu corpo. A artista não apenas faz a apropriação de um elemento religioso - ela amplia essa questão com a apropriação dos gestos, da ausência de fala, primordial na reza.

Trato X. como uma sacerdotisa nessa performance, pois as sacerdotisas podem ser oferecidas como sacrifício em nome de um bem maior ou são as mulheres escolhidas por representarem uma elevação espiritual. Isso pode ser visto em várias

\footnotetext{
${ }^{126} \mathrm{http}: / /$ www.santuarioeucaristico.com.br/liturgia.php?id=12

${ }^{127}$ TVARDOVSKAS, L. S. Corpo e erotismo na produção de Márcia X., p. 674
} 
culturas: na Egípcia, na Xamã, Celta, Mitologia Afro etc. No Brasil, uma sacerdotisa é a mulher responsável por ajudar nos rituais religiosos. Isso é muito comum no Candomblé e na Umbanda. Para Márcia, “o uso de roupas brancas, camisolas e saias pregueadas, contribui para evocar enfermeiras, freiras, noivas, estudantes, filhas de Maria, boas meninas e boas moças, agindo no limite entre a consciência, o sono e o transe religioso. "128

Na zona de leitura na qual estou interessada, Márcia X. possui a mesma representatividade dos rituais do Candomblé ou da Umbanda. Ela é a responsável por levar a oração mais importante. Considero que tratar a obra de X. como um marco do feminino e o enfraquecimento do masculino é fazer sua arte perder potência. Sua escrita é ilimitada e suas escolhas não são simplórias. Quando se entra em contato com o catálogo de Márcia X. produzido pelo MAM, o espectador compreende que tudo é pensado, arquitetado para produzir um significado dos usos do corpo.

Seu corpo é utilizado em Desenhando com terços como o veículo do sacrifício para que Deus pudesse ouvir o clamor da sociedade pós-moderna: as novas subjetividades acerca do corpo e do sexo - os novos arranjos das normatizações. Nesse sentido, chama atenção as pesquisas sobre o tamanho do pênis em cada país ou a quantidade de espermatozoides que um homem ejacula. As medicalizações do pênis, os investimentos na manutenção da ereção do pênis também são evidências da manutenção das normatizações.

O pênis já foi considerado "a Vara do Demônio" e possui uma história cultural. David M. Friedman em Uma mente própria apresenta o pênis como um conceito. O motivo, cito:

A ideia cristã da gargaleira poluída foi um esforço para definir o que não podia ser definido, para entender a lei universal por trás da relação do homem com seu pênis e as questões de 'controle' que levantava. Um homem pode manter a virilidade em suas mãos, mas quem está, de fato, segurando o quê? É o pênis o melhor no homem - ou o bestial? É o homem que controla seu pênis ou seu pênis que o controla? Como deve usá-lo? E quanto ao abuso? De todos os órgãos físicos, somente o pênis obriga o homem a enfrentar tais condições: algo insistente, ainda que relutante, ocasionalmente poético, outras vezes patético; uma ferramenta que cria, mas também destrói; uma parte do corpo que, com frequência, parece separada do corpo. Este é o enigma que

${ }^{128}$ X. M. Disponível em: http://www.marciax.art.br/mxText.asp?sMenu=3\&sText=26 
torna o pênis herói e vilão em um drama que molda todo homem. E a humanidade. ${ }^{129}$

Insisto na proposição de que Márcia pensa amplamente no assunto e não somente em um ataque à Igreja ou ao gênero masculino. Sua obra atravessa as questões do falo como discurso do poder. Arrisco a propor que sua possível reza alerta para uma possível falência do pênis na pós-modernidade. O risco se deve ao fato dos grandes investimentos, desde 1997, em relação ao medicamento Viagra - o pênis medicalizado para que sua rigidez permaneça. Poderia ilustrar tal preocupação enumerando os casos de amputação peniana em jovens que usam indiscriminadamente o remédio. Além disso, a pílula azul originariamente não foi criada para esse propósito. Minha aposta se torna relevante quando há a notícia de jovens viciados no efeito do medicamento. O escritor inglês James Andrew ${ }^{130}$, de 24 anos, cometeu suicídio, pois a namorada descobriu que ele usava secretamente o estimulante sexual. Inúmeros outros casos podem corroborar com a preocupação da falência peniana. O levantado por Márcia X. não se restringiu apenas a performance. Seis anos após sua ideia sair do papel outra questão é abordada.

A performance foi apresentada de 2000-2003. Um fotograma da proposta de Márcia foi censurado em 2006, no Centro Cultural Banco do Brasil do Rio de Janeiro. A questão não estava centrada na performance, já que possui outro suporte. Entretanto, o objeto em questão, o fotograma, trata da problemática poética criada por X. que é a politização estética da sexualidade. De acordo com Luiza Coelho, a sexualidade

se encontra no centro de toda problemática da arte - de todas as formas de arte - e se apresenta como um campo de reflexão que permite tecer muitas considerações, quer de natureza estética, quer social ou política, que possibilitam apontar semelhanças e dissemelhanças dos textos entre si o que os aproxima ou afasta enquanto produtos de diferentes culturas. ${ }^{131}$

\footnotetext{
${ }^{129}$ FRIEDMAN, D.M. Uma mente própria, p. 12.

${ }^{130} \mathrm{http}$ ://saude.terra.com.br/jovens-ignoram-efeitos-colaterais-e-viciam-em-viagra-entenda,5c90a8969ac2a310VgnVCM3000009acceb0aRCRD.html

${ }^{131}$ COELHO, L. Intimidades, p. 8.
} 
Essa questão relaciona-se com o primeiro ordenador, porque o questionamento não foi do sexo fazer parte do centro cultural e, sim, de relacionar o sexo com religião. A exposição Erótica - os sentidos na arte, teve como curador Tadeu Chiarelli, que defende que a proposta naquele momento era "apresentar objetos e objetos de arte que tragam, na constituição material e imagética de todos eles, componentes eróticos evidentes ou sutis, capazes de, reunidos, constituírem uma erótica específica." ${ }^{32}$ Márcia X. leva o sexo para o museu, mas não o sexo com a Religião.

O fotograma proibido leva essa escrita para outro pressuposto: a dicotomia sagrado versus profano. Acredito que a performance necessita de uma interpretação diferente não apenas pelo suporte, mas sobretudo pela atuação de X. e do que foi posto anteriormente em relação aos seus gestos. Segundo Giumbelli,

\begin{abstract}
Quando então procuro apontar para as formas atuais do sagrado, não se trata de proclamar a vitória ou a permanência da religião. Prefiro não reiterar a dicotomia entre sagrado e profano que estrutura a definição durkheimiana do sagrado. A constatação do sagrado caminha lado a lado com a exigência de uma investigação sobre as formas pelas quais se produzem alteridades e identificações em nossa sociedade. Nesse sentido, evita-se também outro princípio da ciência durkheimiana: a transcendentalização da sociedade pela ênfase nos aspectos de coesão e comunhão. A sacralização (...) não anula debates dilacerantes que envolvem dissensos profundos. ${ }^{133}$
\end{abstract}

A linguagem criada por $\mathrm{X}$. trabalha na forma limite e desfaz outras formas instituídas, suas categorias e a recepção. O que ela propõe é uma quebra da organização linear sobre a projeção de suas obras e a apresentação daqueles corpos. Ela age dentro de suas próprias categorias e não as estabelecidas, Por isso, não aposto apenas no questionamento dos gêneros. Márcia traça outras classificações de corpos sempre em movimento a partir de suas intensidades.

${ }^{132}$ CHIARELLI, D. T. Erótica - os sentidos na arte, p. 8.

${ }^{133}$ GIUMBELI, E. A sacralidade do desencanto: breves notas sobre dois conceitos célebres, p.6. 


\title{
4.2 - Objetos e instalações
}
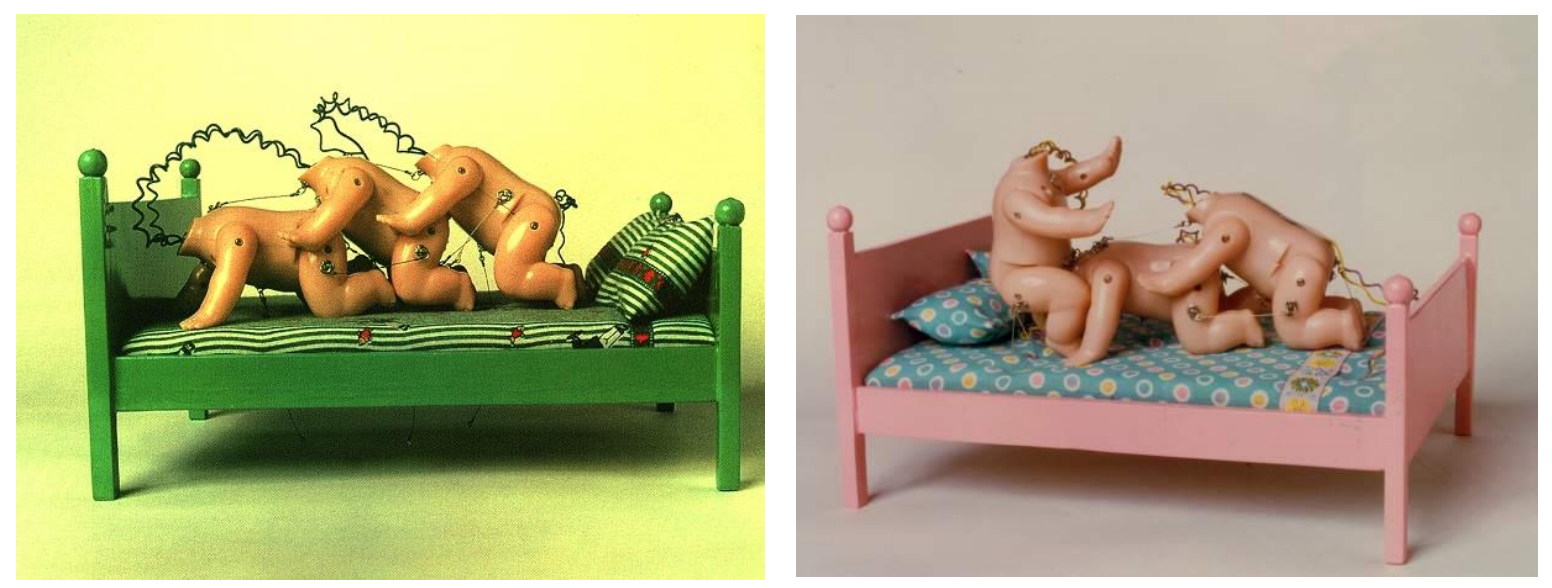

Figuras 2 - Imagens de os kaminhas Sutrinhas

Em segundo lugar: o trabalho de X. com o lúdico como dispositivo do sexo. Nas palavras de Márcia X. a representatividade e a descrição de Os Kaminhas Sutrinhas ${ }^{134}$ :

\begin{abstract}
Na instalação "Os Kaminhas Sutrinhas" (1995), trinta pequenas camas coloridas ocupam o chão da galeria. Sobre elas duplas e trios de bonecos sem cabeça executam uma mímica sexual. Cada cama tem um conjunto de lençol e travesseiros com tecidos de motivos infantis e enfeitados com galões bordados. Os tecidos, os bordados e as posições dos bonecos não se repetem. As roupas assim como as cabeças foram retiradas, restando somente corpos desprovidos de signos de identificação de género masculino-feminino. Os bonecos se encaixam uns nos outros atados por finíssimos cabos de aço. Projetados originalmente para engatinhar, movem braços e pernas enquanto o chip musical entoa "It's a small world" música tema da Disneylândia. Um pedal permite que o público acione todos os bonecos ao mesmo tempo. A cacofonia de sons intensifica a violência da movimentação mecânica contrastando com o visual adocicado. ${ }^{135}$
\end{abstract}

Tratar do sexo e do lúdico sem cair no ridículo foi o que Márcia X. fez nessa

134 Essas obras fazem parte da Coleção Gilberto Chateaubriand, porém as imagens foram retiradas do site da artista.

${ }^{135}$ http://www.marciax.art.br/mxText.asp?sMenu=3\&sText=44 
instalação. O contato inicial dessa pesquisa com a obra Os kaminhas Sutrinhas aponta a retirada das cabeças como algo que será discutido tendo relação com o conceito de biopoder e os dispositivos de sexualidade. A cabeça como o espaço da razão, do limpo, da formação ideológica que se reflete no corpo.

A retirada da cabeça não se reflete apenas no pensar, mas também no ouvir. A questão de estar sem ouvidos e não poder repetir mecanicamente a música que representa, nesse caso, um modo de vida. A Disneylândia que é um mundo de sonhos e fantasias do capitalismo.

Outro modo de vida também questionado é a relação sexual heterossexual, já que X. não determina na sua instalação quem é o feminino ou o masculino. É claro que algumas posições sexuais são mais sugestivas à determinação de gêneros, porém sua estratégia obriga o espectador a refletir sobre aqueles corpos sexuais. Além disso, a imaginação precisa permear a reflexão, pois os eédiges sexuais são questionados - a forma como lidamos com o desejo e o prazer.

Márcia X. utiliza bonecos com o estereótipo infantil na sua instalação. Parto da proposição que a artista questiona a formação ideológica. Esse questionamento se deve ao fato de que, se o corpo é infantil e não possui cabeça, esse corpo pode se deixar levar pelo desejo. Não há padronização, não há estereótipo formado.

A provocação criada por sua arte é imediata como seus espectadores, que possuem uma formação ideológica dentro dos padrões heterossexuais, que pensam as influencias das diferenças sexuais. Espectadores que domesticam seus corpos nos códigos estabelecidos de geração em geração, dos corpos subjugados por numerosas técnicas de controle dos próprios corpos e sua reprodução. Os bonecos de $\mathrm{X}$. desconhecem tais códigos e movimentam-se na busca do prazer sensorial e não pelo desejo controlado pelos modelos patriarcais. O Instituto Antônio Houaiss conceitua a ideologia como:

Ideologia é um sistema de ideias (crenças, tradições, princípios e mitos) interdependentes, sustentadas por um grupo social de qualquer natureza ou dimensão, as quais refletem, racionalizam e defendem os próprios interesses e compromissos institucionais, sejam estes morais, religiosos, políticos ou econômicos. 
A cabeça como o espaço do limpo não existe nesses corpos. Essa não existência faz aqueles corpos movimentarem-se de acordo com outro estímulo. O corpo para além do cerebral, a inscrição de novas experiências, outras inflexões. O questionamento do papel do corpo e da cabeça no sexo. O clamor da alma ${ }^{136}$ do desejo que pulsa no baixo ventre e ecoa pelas terminações nervosas, sem o controle do sistema nervoso central. Logo, o desejo sexual seria algo que demanda outra ordem. Observe o fragmento abaixo que trata de dois fundamentos ocidentais que conduzem as personas sexuais presentes na vida e na arte - que é "atividade propriamente metafísica do homem"137.

Dioniso é identificação, Apolo objetificação. Dioniso é o empático, a emoção simpática que nos transporta para dentro de outras pessoas, outros lugares ou tempo. Apolo é o separatismo duro, frio, da personalidade e do pensamento categórico do Ocidente. Dioniso é energia, êxtase, histeria, promiscuidade, emocionalismo - indiscriminação indiferente da ideia ou prática. Apolo é obsessividade, voyeurismo, idolatria, fascismo - frigidez e agressão do olho, petrificação dos objetos. [...] Dioniso é energia desenfreada, louca, rude, destrutiva, estróina. Apolo é a lei, a história, a tradição, a dignidade e a segurança do costume e da forma. Apolo congela, Dioniso dissolve. Apolo diz "Para!". Dioniso diz “Anda!"[...] Dioniso introduz na matéria movimento e energia: os objetos são vivos, e as pessoas bestiais. Apolo imobiliza os vivos em objetos de arte ou de contemplação. A objetificação apolínea é fascista, mas sublime, ampliando o poder humano contra a tirania da natureza. $[\ldots]^{138}$

\footnotetext{
${ }^{136}$ Após algumas leituras encontrei uma distinção dos verbetes alma e espírito que interessa a essa pesquisa. "Por que, então, São Paulo fala de "corpo, alma e espírito"? Recordando que a Igreja ensina com toda clareza que não são duas almas, mas corpo e alma. Existe, contudo, na única alma humana, o lugar onde Deus habita. Trata-se do "espírito", ou seja, uma realidade sobrenatural que existe nos homens. Assim, aqueles que são filhos de Deus batizados - corpo e alma - pelo fato de serem templo de Deus, possuem um "lugar" onde Deus habita. É possível dizer também que o lugar onde Deus habita enquanto Espírito Santo é que o se chama de "espírito".

A alma como um todo é responsável por diversas coisas: inteligência, vontade, fantasias etc., mas nem tudo isso é o lugar onde Deus habita. Este é lugar mais profundo do homem, onde ele é ele mesmo de tal forma que não é mais ele e sim Deus. "Interior intimo meo", como definiu Santo Agostinho."

Disponível em: https://padrepauloricardo.org/episodios/qual-a-diferenca-entre-corpo-alma-e-espirito

${ }^{137}$ NIETZSCHE, F. O nascimento da tragédia, ou Helenismo e pessimismo, p. 18.

${ }^{138}$ PAGLIA, C. Personas Sexuais: arte e decadência de Nefertite a Emily Dickinson, pp. 99 -106.
} 
Corpos controlados ou reagindo a um remodelar do mundo? O que estaria operando na instalação de X.? Dionísio ou Apolo? Na contraposição entre arte e vida, estou considerando de forma inicial e resumida que o Apolíneo representa os discursos que marcam a exatidão, harmonia, ilusão, prudência. Já o Dionisíaco se expressa de maneira desmedida, amorfa, da primeira ordem, por isso - autêntica.

Márcia X. possui exatidão nas suas escolhas e sua obra aparece de forma consideradamente desmedida. X. incorpora uma potência na produção de sua arte, enquanto o produto de seus pensamentos reage a outra força. A ilusão ocorre aos olhos do espectador: muitos questionamentos - lúdico, infância, sexo, monogamia, Ménage a trois, a sublimação de corpos sexuais infantis.

A sublimação ${ }^{139}$ ocorre porque a obra criada por X tem "a capacidade de liberar energias que estavam investidas em figuras arcaicas para serem investidas em novas figuras. ${ }^{140 "}$ Os arranjos sublimatórios operados nesse processo criativo por vezes foram considerados um catálogo das perversões, porém o jogo que X. faz nos remete a uma reflexão mais ampla. Não há aqui uma análise ou apontamentos que tratem da moral, mas se operasse a leitura dessa obra a partir das perversões, este seria o caminho: X. está tratando das relações sexuais frias, assépticas etc. essa apresentação ou leitura foi realizada por outras pesquisas. Discordo de tais interpretações em razão de não encontrar uma caricatura no trabalho de Márcia.

A energia que vibra na obra da artista e que possui como suporte corpos infantis acionados mecanicamente esgarça o limite do fazer artístico, por isso que há uma associação do seu trabalho a um fazer poético que reclama fluxos da sexualidade. Nas palavras de X. “ eu uso diversos materiais para criar um espaço poético." $" 141$

\footnotetext{
${ }^{139} \mathrm{O}$ uso do conceito sublimação não está sendo usado de forma genérica. A questão é posta a partir do fazer criativo de Márcia, que parece operar uma força questionadora da transformação do prazer. Sendo assim, utilizo esse termo para justificar os símbolos usados pela artista, como por exemplo o corpo infantil. Entendo também que esse conceito está amparado pelos estudos de Freud e Lacan. Porém, como o caráter dessa escrita não é sobre os aspectos funcionais e disfuncionais, não farei uma análise do termo, pois a questão não é tecer um esclarecimento do fazer criativo. Esse conceito não é raso e possui um pacote de pressupostos que necessita de uma análise minuciosa. Contudo, reafirmo que esse trabalho não tem um caráter psicanalítico e trata da relação arte e vida.

140 Disponível em: http://teoriapsicanalitica.blogspot.com.br/2012/08/o-conceito-de-sublimacaoem-psicanalise.html

${ }^{141}$ Bessa, S. X. Rated (duas ou três coisas qu'eu sei dela). In: Revista Item- 4, p. 80
} 
Obra como saída e não como abrigo para pensar a atuação do biopoder com os corpos que agem, reagem e atuam nos modos de distribuição do desejo. Para David Lapoujade, "O problema geral das sociedades é ligar o desejo, quer dizer, submeter seu modo de distribuição esquizofrênico a um regime de disfunções exclusivas, de regras diferenciadas, de distribuições estáveis, instauradora de uma ordem social reprodutível." 142 .

A obra de X. é uma ferramenta que subverte o desejo no corpo sem preconceitos e marcas sociais. Uma reinvenção de um campo da cultura. Como assinala Rivera, "não se trata necessariamente, portanto, de fazer surgir um objeto tal que jamais tenha existido, mas de um agenciamento significante que pode ser como uma bricolagem, uma sutil operação sobre objetos que já estão lá, fora de nós - objetos quaisquer."143

\section{3 - Outros objetos e instalações}

Finalmente, a mistura de questionamentos: Fábrica Fallus. O que aconteceria se a sociedade tivesse a falência do pênis? Márcia ridiculariza ou coloca o pênis como uma questão a ser discutida?

A castração de uma sociedade com suposta falência criaria novos cânones. O órgão masculino possui um papel social que emerge da instalação de X. Márcia pode aproximar sua obra do ritual que foi descrito por Friedman em Uma mente própria: por volta de 275 a.C. os moradores de Alexandria erguiam um majestoso pênis dourado com 55 metros de comprimento, enfeitado com uma estrela na ponta, e o levavam pela cidade, onde aproximadamente meio milhão de cidadãos declamavam poemas em homenagem ao astro da festa, suas qualidades e beleza.

Novamente aproximo o trabalho de Márcia aos rituais pagãos que, nesse caso, pode ser uma oferenda. Cada pênis representa uma oferenda a um tipo social. Por isso, temos todos em riste - por representar fertilidade. Nesse caso, não há a

${ }^{142}$ LAPOUJADE, D. Deleuze, os movimentos aberrantes, p. 158.

${ }^{143}$ RIVERA, T. O avesso do imaginário, p. 112. 
atuação do corpo de Márcia como agente transformador, já que nessa série a associação está sendo realizada aos possíveis rituais e não à figura da Papisa/Sacerdotisa.

Entendo que pode existir certa radicalidade nas interpretações dessas obras de Márcia X. Entretanto, quando há o questionamento do uso de tais elementos, alguns emblemas da cultura brasileira fazem sentido e se justificam. Considerando Fábrica Fallus como uma oferenda, quatro procedimentos são importantes, seguindo os preceitos dos rituais: 1. Só utilizar material novo; 2. Nunca substituir um material por outro; 3. Usar somente o que a receita pede; 4. Ao fazer o trabalho, manter o pensamento firme no que realmente se deseja.

A enumeração acima se torna relevante quando tomo conhecimento do prazer que Márcia possui em escolher seus objetos e circular pela cidade. Márcia assume a escolha do lugar como parte de seu ritual. Leia o fragmento retirado do site da $\operatorname{artista}^{144}$ :

Comprar materiais no Saara para fazer esculturas, instalações e performances significa me apropriar de aspectos simbólicos destes materiais, combinando objetos, imagens e ideias deste universo, associando meu imaginário a elementos do imaginário social relativo a sexo, religião, infância, morte, masculino e feminino.

Márcia X. aciona outro jogo ao grifar Fallus e não falo. O Fallus teria um significado turco. Levantando vários dados da sexualidade masculina, um se torna relevante: os homens turcos exageram no tamanho de sua genitália ${ }^{145}$. A sociedade brasileira também valoriza o tamanho do órgão sexual masculino. Isso é exposto nas anedotas sobre a sexualidade, nos discursos entre jovens e nos modelos veiculados na cultura de massa. Isso talvez traga um caminho para a justificativa dos membros eretos como símbolo da virilidade.

Por outro lado, o trabalho de X. não marca o gozo. Para Friedman, há um rigor religioso que associa incapacidade de procriação e desvio moral. Se não há ejaculação, como trazer à vida minha perpetuação? Se pensarmos que Adão é o pai

\footnotetext{
${ }^{144}$ Disponível em: http://www.marciax.art.br/mxText.asp?sMenu=3\&sText=44

${ }^{145}$ Esse dado foi veiculado após uma pesquisa de fabricantes de preservativos. http://www1.folha.uol.com.br/folha/mundo/ult94u57478.shtml
} 
de todos e que exibe seu pênis com orgulho, entendemos o órgão masculino como um agente.

A questão do sêmen ganha destaque na anatomia masculina a partir dos estudos do médico Andréas Vesalius, autor de Dehumanicorpori fabrica - publicado vinte quatro anos após a morte de da Vinci. Em 1543, o médico publica outro livro intitulado Fabrica, em que faz uma descrição minuciosa não somente do corpo masculino, mas sobretudo do pênis, do sêmen e traz uma grande correção de que a vagina não seria como o pênis ${ }^{146}$.

O nome do livro é sugestivo se associado ao trabalho de X., pois reorganizou questões importantes nas noções de pertencimento das genitálias masculina e feminina. O catálogo de Márcia X. apresenta 44 elementos da série Fábrica Fallus. Segundo X.,

A série Fábrica Fallus (1993-2005) tem como principal componente pênis de plástico comprados em sex-shops. Estas engenhocas sexuais são modificadas pela junção com diversos materiais: pompons, espelhos, medalhas, rendas etc. Anônimos e impessoais nas prateleiras das lojas, acabam por incorporar "personas" diversas, transformando-se em objetos simultaneamente fálicos e femininos, pornográficos e infantis, sagrados e profanos. As peças que utilizam vibradores se movimentam pelo chão, se encontram e se afastam, rodopiam percorrendo o espaço, formando ao acaso uma estranha coreografia. ${ }^{147}$

Márcia fala em coreografia, em convenções sociais e códigos morais em posições antagônicas. A proposta de X. coloca em tensão as formas de organização sociopolíticas que constituem as classificações. A artista traz para o primeiro plano atos de feitiçaria que tratam da alta potência do existir. Sua obra atravessa normas, trabalha com a ilogicidade - rompe com o aparelho perverso da repressão.

Essa série codifica questionamentos enraizados na sociedade. A obra foi tocada pela teoria, pois sua "linguagem desarticulada feita de sopros, de gritos" 148

\footnotetext{
${ }^{146}$ No século XVI, Galeano afirmava que o pênis e a vagina possuíam a mesma anatomia. Galeano acreditava que o pênis na mulher desenvolvia-se para dentro.

147 X. M. Natureza Humana. Disponível em: http://www.marciax.art.br/mxText.asp?sMenu=3\&sText $=44$

${ }^{148}$ LAPOUJADE, D. Deleuze, os movimentos aberrantes, p.153.
} 
opera símbolos que são agentes de deslizamentos para a livre circulação das intensidades de novas apropriações desses símbolos.

Márcia X. refaz as noções sobre o corpo e inscreve sua arte no debate político sobre a sexualidade. O movimento criado pela artista é uma liberação dos gestos, que serve como um autenticador do refazimento do corpo. A série trata do corpo comunicativo, uma vez que propicia novos encontros, outros sentidos.

\section{4 - Medalhinhas}

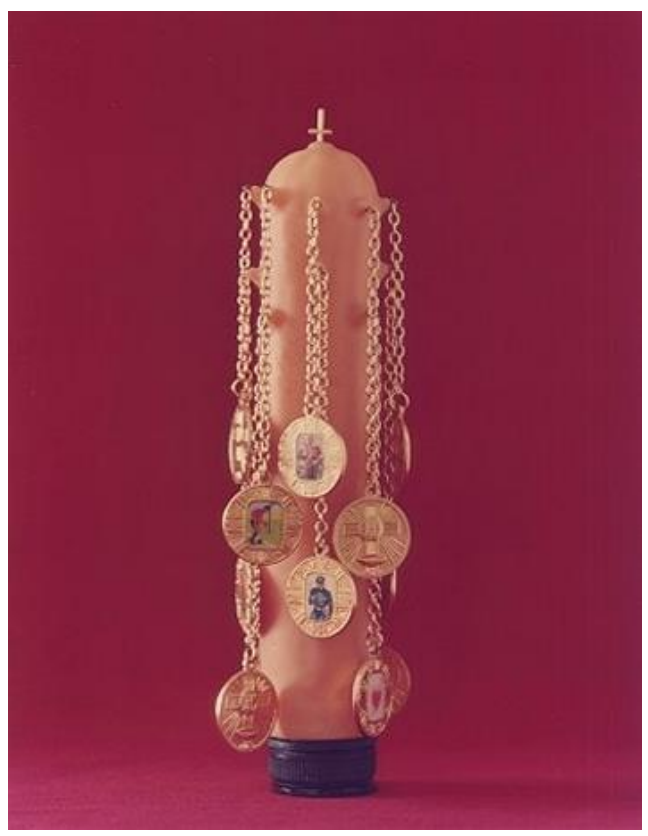

Figura 3 - Imagem da obra As Medalhinhas

A obra dessa série intitulada de Medalhinha apresenta um pênis de um homem branco, com aproximadamente 16 medalhinhas. O uso de alguns símbolos é provocativo, como a imagem de um jogador de futebol no espaço reservado para um santo, um super-herói, um coração, uma imagem de São José - considerado "Padroeiro das Famílias e Trabalhadores", uma medalha com o símbolo da Eucaristia $^{149}$.

\footnotetext{
149"A Eucaristia é um mistério altíssimo, é propriamente o Mistério da fé, como se exprime a Sagrada Liturgia: Nele só, estão concentradas, com singular riqueza e variedade de milagres, todas as realidades sobrenaturais. [...] Sobretudo deste Mistério é necessário que nos aproximemos com humilde
} 
X. é pontual na escolha dos seus símbolos. Ela não os utiliza aleatoriamente: o símbolo da Eucaristia, por exemplo, representa na comunhão a recriação da Última Ceia e encarna o culto do corpo de Cristo, sacrificado em nome da humanidade. Um corpo criado pela partícula de Deus no corpo de uma mulher virgem. Alguns dogmas da Igreja estão sendo postos em questão quando a artista utiliza essa medalha. Márcia poderá usar outro símbolo se quisesse atacar a instituição Igreja, mas ela usa o corpo de Cristo (representatividade) como adorno peniano.

Na questão proposta por Márcia temos o corpo de Cristo pendurado no pênis, juntamente com o corpo de um Santo, um super-herói e um jogador de futebol. Seria a consolidação de um falo "perfeito" ou a busca de um significado ainda não estabelecido? Insisto que a artista não quer somente atacar uma religião, mas refletir criticamente os aparelhos da repressão. O único que teria uma sexualidade ativa seria o jogador de futebol, o homem másculo de corpo atlético que permeia o imaginário fetichista.

Essa produção trata dos imperativos de corpos que são produzidos pelas potências de significação. Márcia usa duas figuras divinizadas: José e o super-herói. José, pelo fato de aceitar a gravidez que não ocorre pelo coito, pelo sêmen, e sim por uma partícula de Deus - algo imaterial. O super-herói, pela construção do imaginário de herói que não passa pelas necessidades fisiológicas do homem. Duas figuras que são superiores ao fazer humano. Dois homens que não são representados pelos seus órgãos ou a eficácia sexual.

respeito, não dominados por pensamentos humanos, que devem emudecer, mas atendo-nos firmemente à Revelação divina" (carta encíclica Mysterium Fidei).

As palavras do Papa Paulo VI ajudam-nos a compreender o papel da sagrada liturgia. Somos, por natureza, apegados aos sentidos. Diante de uma realidade sobrenatural, como o é a santa missa, a liturgia vem em nosso socorro, para que, através de símbolos e gestos concretos, alcancemos o entendimento daquilo que pela fé cremos. Não que se exija do fiel que o mistério seja plenamente entendido, pois este é, antes, para ser crido, mais que explicado; mas, iluminados pela sagrada liturgia, possamos dirigir a Deus o culto de adoração que lhe é devido, de modo que a nossa oração seja um espelho fiel da nossa fé."

Disponível em: http://www.ahoradamissa.com/doc_glossario.html 


\section{5 - Touch me}

Touch $m e^{150}$ representa o pênis do homem negro que precisa ser tocado para ter funcionalidade. A voz da boneca Barbie declara ao espectader: "I love you", quando esse possui coragem para acionar um botão na glande do objeto. Márcia traça um paralelo com o estereótipo do negro bem-dotado como um exemplar de virilidade. É importante salientar que nessa obra o espectador precisa tocar na genitália e apertar a glande - que é considerada pela biologia como a parte sensível do órgão masculino. A glande está cravejada de um material que não consigo determinar pelo catálogo, porém evoca uma sensação no espectador que se propõe a tal experiência. Além disso, possui uma faixa dourada com o dizer touch me. $\mathrm{Ob}$ serve o objeto pensado por Márcia:

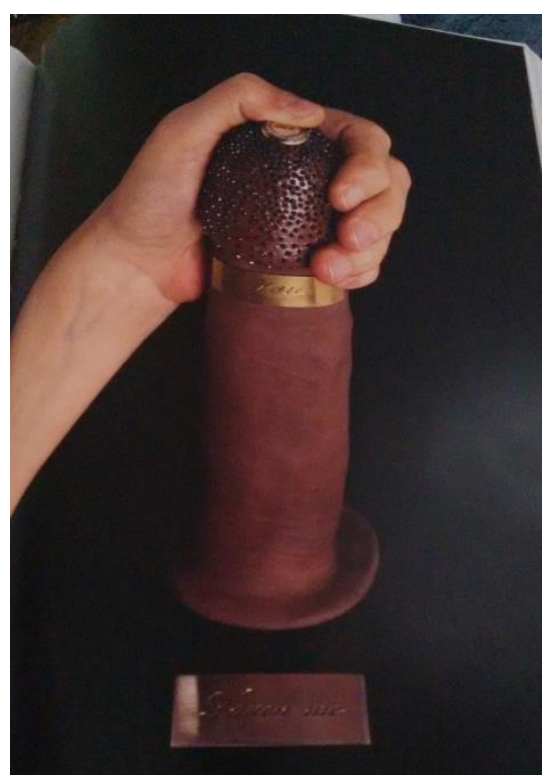

Figura 4 - Fotografia retirada do catálogo da artista

De acordo com as teorias levantadas por Friedmam,

depois da Guerra Civil, o pênis preto lançou uma grande e alarmante sombra sobre muitos brancos, que temiam que a sua emancipação significasse a liberdade dos negros macrofálicos de terem relações com as mulheres brancas $-\mathrm{e}$, o que era pior, que as mulheres brancas pudessem preferi-los. ${ }^{151}$

\footnotetext{
${ }^{150}$ A imagem é uma fotografia do catálogo de Márcia X, pois não há imagem disponível desse objeto. A fotografia foi retirada da página 289.

${ }^{151}$ FRIEDMAN, D. Uma mente própria, p. 109.
} 
A genialidade de X. aparece quando ela "obriga" o toque para que a obra atue. $\mathrm{O}$ toque, a manipulação do pênis proibido. $\mathrm{O}$ órgão que representa a potência sexual documentada pelo pesquisador britânico Havelock Ellis, em 1913. Se o caráter de um homem era medido pelo tamanho de sua genitália, o homem negro, segundo as proposições de Friedman, sempre sairia perdendo, pois o preconceito imperava pela disputa de poder. Dessa forma, o homem branco condenou o pênis do homem negro. Márcia X. fundamentaliza outra intensidade: o delírio do pênis negro que vibra outras questões e reage ao toque do indivíduo que se permite recriar as experiências.

Márcia usa a representatividade da voz da boneca Barbie. Seria a menina branca, capitalista, que atravessa as esferas do poder para talvez marcar sua preferência: a experiência de dar vazão a um desejo sexual. A boneca Barbie representa a subjetividade das meninas brancas que são comportadas, meigas, amigas, bonitas e inteligentes.

A obra de Márcia também provoca um debate sobre essa questão no Brasil, marcado por uma formação mestiça. Além disso, inúmeros comportamentos são baseados no cabelo, no corpo e no modo de vida produzidos para essa boneca, que representa um marco na criação de subjetividades como produção de necessidades cabelo liso, louro, padrão de beleza e estímulo de procedimentos estéticos. O uso da cor rosa também é um marco na sociedade, pois comumente meninas que usam excessivamente essa cor são chamadas de Barbies. Uma escultura viva em forma de gente provoca desejos, dos mais diversos e inimagináveis. Anselm Jappe acredita que,

o poder da imagem de um corpo é o resultado de uma sociedade que anula a vida em proveito de contemplação passiva de imagens, escolhidas por outros, que substitui o vivido e a determinação dos acontecimentos pelo próprio indivíduo ${ }^{152}$.

152 JAPPE, A. In NOVAES, A. A imagem e o espetáculo, p 15. 
Os jogos de poder que atuam e produzem corpos. Corpos com necessidades criadas por um sistema que precisa ser retroalimentado para sobreviver, por isso produz incessantemente primordialidades no corpo social.

Se o poder se realiza por todo o corpo social, é porque a liberdade está por todas as partes e, sendo assim, sempre cabe a possibilidade de transformar as coisas. Do mesmo modo, se o poder é cada vez mais elaborado e complexo em seu exercício, e penetra criando desejo, provocando o prazer, produzindo o saber, será preciso surpreendê-lo neste trabalho com os comportamentos e o corpo. É necessário estabelecer qual o papel a ser jogado pela liberdade, identificar o que resiste a um sistema de sujeição específico. ${ }^{153}$ ( Grifo meu).

O corpo do homem negro e seu pênis ainda é um problema a ser repensado. Os preconceitos instaurados séculos atrás não evoluíram. Tais questões têm permeado um acirrado debate em Nova York com protestos e inclusões de artistas negros que sofrem repressões e desconfianças pela cor da sua pele e por preconceitos ainda incitados. No Brasil, isso ocorre de uma maneira também agressiva. Jogadores de futebol hostilizados, cidadãos impedidos de permanecerem em espaços públicos, agressões verbais, desconfianças de violência sexual. Todas essas questões foram construídas por uma luta de espaços e hoje travam conflitos que atrasam o desenvolvimento social.

O tamanho do pênis ou sua força sexual não deveria determinar o caráter de um homem. Nenhum homem deveria ser excluído socialmente por tais questões e o Brasil ainda precisa avançar nesse debate. Não falo apenas do sexual, mas sobretudo pelos posicionamentos de que ser negro é uma questão da cor da pele, da obrigatoriedade de falar das religiões afro, da literatura africana. Essas questões devem ser naturalizadas no Brasil, porque somos mestiços, temos o traço e o sangue daqueles que ajudaram na construção da nossa cultura como um todo e não apenas em alguns campos. O desejo nacional: a bunda vem do vocabulário africano. A tão desejada bunda também sofre um preconceito quando a sodomia entra em questão. Observe o objeto criado por Márcia $X^{154}$.

153 ORELLANA, R.C. A ética da resistência, p. 50.

${ }^{154} \mathrm{O}$ objeto criado pela artista Márcia X. faz parte da Série Fábrica Fallus e não possui título. Disponível em: http://www.marciax.art.br/mxObra.asp?sMenu=1\&sObra=37 


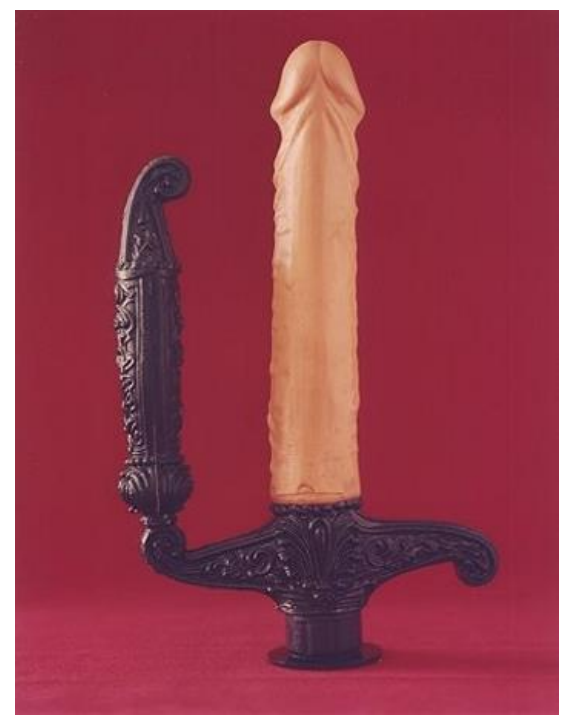

Figura 5 - Objeto da Série Fábrica Fallus

Uso um fragmento de Phillippe Sabot ${ }^{155}$ para pensar na rede discursiva que gira para além do sexo heterossexual ou homossexual.

a noção de sexo assegurou um retorno essencial; ela permitiu inverter a representação das relações de poder com a sexualidade e de fazer com que essa apareça não direto na sua relação essencial e positiva com o poder, mas como ancorada em uma instância específica e irredutível que o poder busca como pode sujeitar.

Pensar a questão sexual na obra de X. como a possibilidade de refazer, recriar as experiências precisa também ser operada por esse tipo de ato: o anal.

A sodomia possui histórias culturais, sociais e históricas. O que penso aqui é a provocação criada por Márcia ao não intitular a obra, mas sugestionar a dupla penetração. Observe que a artista não abre espaço para três no ato. O que está representado é uma remissão a uma espada. Tudo faz parte do mesmo tronco, origem, base, porém de um lado um pênis branco e, ao seu lado, fruto da mesma base, um objeto preto que incita tal pensamento.

Usarei como recurso o episódio polêmico que usa a fala da cantora Sandy sobre o assunto. Abaixo, um trecho da entrevista ${ }^{156}$ :

\footnotetext{
${ }^{155}$ Palestra com Philippe Sabot, Université de Lille 3, França:Sexualidade e identidade, uma leitura cruzada de Foucault e Butler em 19 de novembro de 2015 na PUC Rio.

${ }^{156}$ Disponível em: http://ego.globo.com/Gente/Noticias/0,,MUL1669535-9798,00-
} 


\section{Pergunta da Playboy - Dizem que as mulheres não gostam de sexo anal. Você concorda com isso?}

Resposta da Sandy - Então... Não tem como não responder isso sem entrar numa questão pessoal. Mas, falando de uma forma geral, eu acho que é possível ter prazer anal. Sim, porque é fisiológico. Não é todo mundo. Deve ser a minoria que gosta.

Pergunta da Playboy - Uma minoria na qual você se inclui?

Resposta da Sandy - Não vou dizer. Essa é uma pergunta que me faria pôr em prática minhas aulas de boxe (risos).

Entendo que a referência a esse fato pode levar a explosão artística criada por X. para algo corriqueiro do cotidiano, porém acredito que esse possa ser o melhor exemplo, porque foi incessantemente debatido. A obra de Márcia pode ser esquecida do imaginário do espectador, contudo não o discurso de uma cantora que cresceu na frente da população brasileira e possui todos os quesitos da representatividade de um comportamento modelo. Sandy já foi considerada a namoradinha do Brasil. A cantora representa não apenas um modelo de bom comportamento como possui a força de determinar comportamentos: a menina educada, de fala baixa, que não aborda a temática sexo em público, que não transgride comportamentos, estudiosa e que é fruto de um casamento duradouro e tradicional.

A revista Playboy só acirrou o debate em torno da cantora, pois já havia toda uma questão de Sandy estrelar o comercial da cerveja Devassa. Esse encontro de discursos interessa a essa pesquisa, pois incentiva a discussão não apenas do campo semântico, mas da associação ao comportamento inapropriado. A sodomia é vista através de uma prática homossexual ou de mulheres consideradas sujas.

Uma exposição em Paris ${ }^{157}$ trouxe o ânus para um destaque nas artes. Tom $Z^{158}$ utilizou a mesma abordagem na capa de seu disco, em 1973. Atores fazem

\footnotetext{
${ }^{157} \mathrm{http}: / /$ www.diariodocentrodomundo.com.br/uma-exposicao-de-fotos-anais-e-arte/ ${ }^{158} \mathrm{https} / / /$ chicoandrade.wordpress.com/2011/11/15/inedito-foto-original-da-capa-do-disco-detomze/
} 
uma performance e manipulam o ânus de seus colegas de cena ${ }^{159}$. Três exemplos de tentativas ou provocações que tratam de um tema áspero, polêmico, quase com um tom de proibido. Por isso, a importância não somente do objeto criado por X., mas sobretudo o investimento da não saturação dos discursos sobre sexo, corpo e empoderamentos. Nas palavras de Drummond, em As contradições do corpo:

Meu corpo não é meu corpo, é ilusão de outro ser. Sabe a arte de esconder-me e é de tal modo sagaz que a mim de mim ele oculta.

Meu corpo, não meu agente, meu envelope selado, meu revólver de assustar, tornou-se meu carcereiro, me sabe mais que me sei.

Meu corpo apaga a lembrança que eu tinha de minha mente.

Inocula-me seus patos, me ataca, fere e condena por crimes não cometidos.

O seu ardil mais diabólico está em fazer-se doente. Joga-me o peso dos males que ele tece a cada instante e me passa em revulsão.

Márcia X., com sua escrita dilacerante, apresenta outro modo ao referir-se aos aspectos manipulatórios da indústria que produz discursos sobre corpo, sexo, desejo etc. em busca de um poder, mas que na pós-modernidade se amplia para novas produções, não somente de comportamento como de pensamentos dos possíveis corpos que decorrem das recriações de experiências. X. é uma experiência atemporal que refaz corpos e imagens com um duplo movimento - sair de si e trazer um mundo novo para dentro de si.

\footnotetext{
${ }^{159} \mathrm{http}: / /$ www.diariodocentrodomundo.com.br/uma-exposicao-de-fotos-anais-e-arte/
} 
A questão do corpo nas propostas de Márcia X. destitui os discursos de que há uma "redução da sexualidade a algo que pode comercializar-se"160. Sua arte propõe o desconhecido que rompe com certas barreiras. Ela investe em outras formas de vida, uma vida não tão regulada e logicamente não delimitada. Suas questões forçam uma reapropriação do conceito de biopoder por esses outros investimentos. Lembrando que o biopoder atua na organização do poder sobre a vida, fator que pode ser associado a medicalização excessiva do pênis na pós-modernidade.

${ }^{160}$ VILLAÇA, N. A edição do corpo: tecnociência, artes e moda, p. 82. 


\section{5 - Conclusão}

É o gesto, o movimento, essa engenhosidade do corpo humano que não para de produzir linguagens.

Ivaldo Bertazzo

\section{Como cheguei aqui?}

Escrever um trabalho de conclusão para esta etapa acadêmica não é fechar o processo. Essa pesquisa não é datada. Pensar sobre algo é traçar influências. É abrir as portas, não apenas uma em que as coisas, os conceitos, entram de maneira ordenada. Escolher o tema para o trabalho é pensar na construção de um corpo recortado, partilhado, atravessado e não definido. Esse processo esbarra em alguns debates, mas não se fixa a nenhum deles.

Para formular esta proposta de pesquisa, usei como fundamento dois textos e um curso: Para acabar com o julgamento de Deus de Antonin Artaud, O que é preciso para se refazer o corpo? de Ana Kiffer e "Escrita Artística e Produção de Pensamento", de Fred Coelho, respectivamente. Após a junção desses dispositivos, formulei a indagação, remetendo-me a outros estudiosos de corpos: Como o conceito de erotismo proposto por Georges Bataille e os discursos sobre biopoder, partindo das proposições de Michel Foucault, poderiam refazer o corpo? O campo de pesquisa que me interessou nesse debate crítico foi o das questões referentes ao corpo que vão para além das convenções estéticas ${ }^{161}$. As mudanças culturais abrem uma reflexão do agenciamento do corpo como produção de novas subjetividades.

Partindo desses pressupostos, a corporeidade é uma questão política e não pode ser tratada como elucubrações emblemáticas, pois, de acordo com a bibliografia levantada, o corpo, assim como a cultura, deve ser entendido e debatido também como parte da história social e identitária do sujeito. Apoio-me em Rogério Rosa, na etapa final desse trabalho,

${ }^{161}$ Referência ao discurso da professora Ana Kiffer em seu curso: Os limites do literário: $O$ caso de Antonin Artaud e seu legado, 2014. 
o corpo implica uma porosidade e uma vulnerabilidade ao mundo que o cerca. $O$ corpo é atravessado pelas vibrações que o cercam, daí, desliza, se transforma, escapa, muda de forma, contagia, afeta e é afetado. Ele é, no mundo, passivo ativo: paradoxalmente. A todo esse movimento transformacional do corpo-nomundo; a todas essas derivas e desdobramentos que lhe são possíveis, chamamos: corporeidade! Então, mais precisamente, corporeidades são as fugas e delírios do corpo. ${ }^{162}$

Pensar na representação da escrita de um eөrpe, na mudança de máscaras que vão contando/construindo uma história, que vai atuando. Que se encaixa no momento que aqui escrevo exatamente como um corpo entremeado que representa várias experiências. $\mathrm{O}$ corpo de quem escreve o aqui e o agora é a partir de um pensamento fraturado, refeito, com tensões que não chegam a um objeto fechado e pensado linearmente. Ele representa algumas vozes que se complementam e outras que se repelem.

A escolha de Marcia X. e Cassandra Rios, no contexto cultural a partir de 70, deveu-se aos modos de interferência social das artistas como "dispositivo" de resistência ao estabelecimento de diferenciações fechadas, explorando, assim, os aspectos do comportamento sexual/erótico na fixação de identidades. Esta proposta considera que, na busca da identidade, o processo de diferenciação é estabelecido pelos campos de forças que são impostos por alguns vetores, como a demarcação de fronteiras, a classificação, as normatizações, os pertencimentos. As relações de poder atuam nesses vetores de força.

Quanto à noção de dispositivo, Agamben, fazendo uma apropriação do termo utilizado por Foucault, diz que:

[...] chamarei literalmente de dispositivo qualquer coisa que tenha de algum modo a capacidade de capturar, orientar, determinar, interceptar, modelar, controlar e assegurar os gestos, as condutas, as opiniões e os discursos dos seres viventes. ${ }^{163}$

\footnotetext{
${ }^{162}$ ROSA, R.N. Sobre o corpo e corporeidade. Disponível em: http://nuvic.com.br/2012/03/sobrecorpo-e-corporeidade

${ }^{163}$ AGAMBEN, G. O que é contemporâneo? e outros ensaios, p. 40.
} 
Dispositivo como condição militante para pensar todos os corpos, desta pesquisa, que atuam nesse confronto das relações da sexualidade que se apresenta sob a forma do erotismo. Isto moveu essa investigação: a escrita desse texto e os pensamentos sobre a energia propagadora dos corpos artísticos analisados. É importante destacar que as linhas de forças apresentadas são multifacetadas. Logo, não adianta pensar apenas por uma perspectiva. Sendo assim, fiz em alguns momentos apostas e não afirmações categóricas.

O trabalho possui um caráter especulativo, uma vez que investe nas múltiplas temporalidades de gozo. Dessa forma, aborda excreções e secreções que dão o tom dos excessos do corpo que atravessam a boa conduta Nesse sentido, a investigação trata de experiências que possam refazer o corpo e que são interpretadas a partir de uma zona de leitura que fui construindo não somente a partir de teorias, mas também de apostas interpretativas.

De um lado, a potência narrativa de Cassandra Rios com suas problemáticas acerca do desejo, que fizeram parte de um contexto que nega ou ridiculariza suas propostas. Sua escrita aborda os conceitos primordiais que levantei nessa trajetória: corporeidade, biopoder, erotismo e refazimento do corpo. Cassandra fala de corpos que não se restringem à condição normativa estabelecida por um corpo social tradicional. Ela traz para sociedade brasileira os assuntos que não são toleráveis. Isso liga o trabalho dessa autora a um debate amplo e que não se esgota aqui.

Trazer Cassandra para essa pesquisa foi entender como essa escrita artística produz pensamento sobre corpos provocadores. Cassandra, em certa medida, reconfigura um pensamento sobre os corpos que atuam em busca do desejo. A tradução de um mundo que reafirma a pungência de outras formas de singularização de vida.

As questões trabalhadas por Márcia falam de uma performação discursiva que proporciona questionamento em relação a uma cultura de ruptura, pois temos novos valores, novas posições. Talvez as obras de Márcia precisem ser vividas mais do que narradas.

Sua abordagem aos elementos do Cristianismo nos faz pensar nas tentativas da instituição religiosa em rebaixar os corpos. Tal rebaixamento obriga a uma exclusão do erotismo no corpo. Colocar o corpo no lugar do sujo é sufocar o desejo. 
Márcia refaz essa questão quando ocupa espaços com suas obras que possuem forças que agem sobre a matéria.

A força de que tanto falo é tudo o que desestabiliza a forma e nos arrasta. No caso de X., aquilo que atravessa o corpo físico, pois a artista em questão faz obras com forças de ebulição. Nesse caso, o erotismo refaz o corpo porque essa arte eleva o corpo. Logo, rompe com o lugar do sujo e do proibido. Ela constitui um novo conceito de obra e vida, não se tratando do para quem ou para além. Essa artista não transita nos conceitos que operam uma lógica já posta. Sua escrita inscreve a possibilidade de repensar as lógicas reguladas.

Os corpos que simulam a corporeidade são os corpos da relação. Corpos que traem, pois criam uma nova forma de expressão e rompem com uma linearidade. As atuações das inovações contemporâneas dos corpos e da apreensão de mundo funcionam como uma arena, visto que, "o corpo e sua subjetividade são os campos de luta, são os espaços onde se dão os embates entre os modos de ocupação e resistência." 164

Qual é o lugar dessas escritas? De artistas que produzem forças que desestabilizam normas e conceitos? Uma aposta importante a essa altura é que Cassandra e Márcia destacam gestos esquecidos, já que tratam de corpos que propõem sensações e fazem uso das brevidades das formas. Elas apoderam-se da sexualidade como uma forma de repensar as repressões e refazer o corpo. Márcia X. e Cassandra Rios são artistas que se referem aos corpos vivos e gloriosos, pois não estão anestesiados ou mortos. Estão pulsando possibilidades, um corpo que

funciona por espasmos, contrações e distensões, dobras, desdobramentos, nós e desenlaces, torções, sobressaltos, soluços, descargas elétricas, distensões, contrações, estremecimentos, sacolejos, tremores, horripilações, ereções, arquejos, arroubos. Corpo que se eleva, se abisma, se escava, se descama e se fura, se dispersa, zanza, escorre e apodrece ou sangra, molha e seca ou supura, grunhe, geme, resmunga, estala e suspira. ${ }^{165}$

${ }^{164}$ PIRES, E. Cidade ocupada, p. 211.

${ }^{165}$ NANCY, J.L. Corpo, fora, p. 98. 
Essas táticas de resistência são expostas através das lambidas de Flávia nas sandálias de dona Kênia, no abuso de drogas de Andréa, no corpo libidinoso de Ana Maria e suas manobras para não revelar o seu sexo. Além disso, no toque do pênis do homem negro, nos penduricalhos do pênis do homem branco, nos bonecos que estão em um ritmo alucinado e na cacofonia produzida por sua instalação.

Márcia X. possui influência de artistas anteriores ao seu tempo. Suas obras possuem um deslocamento das formas que traz uma intensidade indomável. Por isso, minha dificuldade em tratar de sua linguagem. Suas propostas reúnem um largo campo de referências sobre o corpo e as formas da sexualidade. Essa artista redescobre os limites sutis que aparecem nos intervalos, mas que possuem intensidade, uma vez que convoca um corpo que confunde gestos e ações. O corpo como superfície de inscrição. Nas palavras de José Gil:

A tensão entre estes dois vetores - esgueire e equívoco, intervalo e confusão - desemboca num equilíbrio instável: a situação original de um intervalo que põe um "interior" amorfo é acompanhado por um equívoco que impõe aderências tão estreitas entre a expressão e o expresso que um dos temas não consegue desprender-se por completo um do outro: não há "hipocrisia" fora da expressão corporal ou facial da hipocrisia. Mas o sentido de "hipocrisia" não se esgota nesta expressão: permanece o intervalo entre o expresso e a expressão, como persiste entre o fundo informe e a forma que incarna o sentido. Se há intervalo inicial entre o que se vê no corpo do outro e o que ele significa (para além do que significa aquilo que se vê) é porque qualquer coisa de absolutamente irredutível (à presença para a qual remete o signo ou a forma) escapa à significância do visível. Não se trata do que, do sentido, não é signo ou não é significável; mas, mais profundamente, daquilo que não sendo nem indizível nem inefável, cai fora da esfera tanto do signo como do sentido, não é nem coisa a dizer nem coisa a denotar. Isso, que não tem nome, é um lugar não inscrito, lugar do intervalo entre o visível das formas do corpo e o informe que procura tomar forma; a esse lugar, não há símbolo, nem índice, nem forma que o nomeie porque não é nem conteúdo psíquico, nem um lugar físico, nem um pensamento; não é um sentido nem um não-sentido. Mas só ele permite aos pensamentos que se formem e ao sentido tornar-se não-sentido; aos signos significarem e às formas surgirem e combinarem-se. ${ }^{166}$

${ }^{166}$ GIL, J. A imagem-nua e as pequenas percepções, pp. 297-298. 
Márcia e seu plano infinito de forças que desestabilizam os anos 2000, em razão de usar símbolos e critérios que rompem com a tradição. O lugar e a importância do pênis, a energia propagada por uma reza e as intensidades que esse ato evoca na introspecção de uma fé, colocada à prova em Fábrica Fallus ao apropriarse de um símbolo da eucaristia.

$\mathrm{X}$. e suas questões que explodem barreiras, suas fusões e ensaios que desbravam limiares entre os limites no contemporâneo. Sua arte é violenta no tratamento do biopoder, pois incita outros limites para a vida e as formas de controle da pedagogia do corpo.

Cassandra Rios e sua trajetória nas bancas de jornal. A classificação injusta da sua escrita que ainda é considerada baixa literatura. Sua provocação com a língua de Flávia que como criança lambe os pés de sua amante. O uso da boca que não fala, mas que usa sua língua para desbravar o mundo ao seu redor.

A autora nos força a superar os parâmetros sobre o corpo da mulher, da criança e de tipos sociais como o travesti e a professora. Cassandra, ao dar tratamento literário à personagem Berenice, aborda um comportamento que tangencia a admiração e os controles da sujeição. Os atos de uma professora que, de acordo com sua função, rompe com a organização da dimensão social, política e econômica concebidas para esse tipo de relação.

Trato dona Berenice como predadora sexual, pois há a repetição de um modo de agir, a recorrência de um comportamento não apenas com Andréa, mas com sua mãe, Júlia, e outras meninas na narrativa. Um padrão na sua conquista, na forma de possuir outros corpos.

A maneira como o sexo oral é trabalhado na narrativa As traças foi aproximada do recurso cinematográfico Azul é a cor mais quente, filme considerado obsceno por abordar outros limites para o corpo e o sexo lésbico. Cassandra, assim como Kechiche, é transgressora nos espaços da vida em sociedade, ao apresentar o corpo feminino como ator do prazer, na oscilação das forças vitais, nos vazamentos desordenados onde propaga-se forças e poderes.

Cassandra e suas marcas, sua literatura censurada, seu debate sobre o erotismo que desterritorializa a regulação dos corpos. O atravessamento das esferas 
sociais que produz dobras imperceptíveis, mas que emergem na escrita da autora. Uma artesã que cria uma nova apreensão da sexualidade feminina.

A escrita desse trabalho é extensa no sentido que extrapola esse texto. A minha questão é pensar o movimento dos corpos que apresentam novas subjetividades, a emergência de efemeridade dos delineamentos, os graus que atravessam o corpo que rejeita entregar-se à articulação imposta por um influxo. O refazer o corpo com novas experiências do erotismo 


\section{6- Referência bibliográfica}

ABREU, C. Morangos mofados. Rio de Janeiro: Nova Fronteira, 2015.

AGAMBEN, G. Nudez. Lisboa: Relógio d'agua, 2010.

O que é contemporâneo? e outros ensaios. Chapecó: Argos, 2009.

ANDERSON, P. As origens da Pós-Modernidade. Rio de Janeiro: Zahar, 1999.

ARIÉS, P. História Social da Criança e da Família. Rio de Janeiro, Zahar, 1981.

ARTAUD, A. Eu, AntoninArtaud. s/d - fragmento retirado de xerox.

Mensagem ao Papa. In: Cartas aos Poderes. Porto Alegre: Editorial Villa Martha, 1979. (Coleção Surrealistas - Vol. 1)

Para acabar com o julgamento de Deus. 1948 - texto retirado da internet. Disponível em: http://www.psb40.org.br/bib/b75.pdf

BARTHES, R. O óbvio e o obtuso. Rio de Janeiro: Nova Fronteira, 1990.

BATTAILlE, G. História do olho. São Paulo: Cosac Naify, 2013.

O erotismo. Belo Horizonte: Autêntica Editora, 2003.

BEIRUTTI, E. B. Gays, lésbicas, transgenders: o caminho do arco-íris na cultura norte-americana. Rio de Janeiro: EdUERJ, 2010.

BENJAMIM, W. Experiência e pobreza. In: Magia e técnica, arte e política. Ensaios sobre literatura e história da cultura. Prefácio de Jeanne Marie Gagnebin. São Paulo: Brasiliense, 1987, p. 114-119.

BHABHA, H. K. O Local da cultura. Belo Horizonte: Editora da UFMG, 1998.

BORTOLANZA, E. C. Gestos pornográficos: desejo, estética e erotismo. Dissertação (Mestrado em Psicologia Clínica) - Departamento de Psicologia, Pontifícia Universidade Católica de São Paulo, São Paulo. 2006.

BROWN, N. O. A Ressurreição do Corpo. In: Vida contra morte: o sentido psicanalítico da história. Petrópolis: Vozes, 1972.

BLOOM, H. Linguagem faz êxtase de "Lolita”. Folha On-Line, São Paulo, 1994. Disponível em: http://biblioteca.folha.com.br/1/01/1994070101.html 
BUTLER, J. Problemas de gêneros: feminismo e subversão da identidade. Trad. Renato Aguiar. Rio de Janeiro: Civilização Brasileira, 2003.

Corpos que pesam: sobre os limites discursivos do "sexo". In: LOPES LOURO, G (org.). O corpo educado. Pedagogias da sexualidade. Belo Horizonte: Autêntica, 1999, p, 151 -172.

. CONFERENCIA MAGNA COM JUDITH BUTLER 9/9 das 16h às $18 \mathrm{~h}$ I Seminário Queer Português. Disponível em: https://www.youtube.com/watch?v=hydaHt7pd70\&feature=youtu.be

CARDOSO, C. F. S. Epistemologia pós-moderna: A visão de um historiador. In: FRIGOTTO, G; CIAVATTA, M. (Org.). Teoria e educação no labirinto do capital. Petrópolis: Vozes, 2001, v. 01, p. 75-90.

CARNEIRO, B. S. Cosmococa - programa in progress: heterotopia de guerra. In Seguindo Fios Soltos: caminhos na pesquisa sobre Hélio Oiticica. (org.) BRAGA, P., edição especial da Revista do Fórum Permanente (www.forumpermanente.org) (ed.) Martin Grossmann.

CHALHOUB, S. Trabalho, lar e botequim. São Paulo: Editora da UNICAMP, 2001.

CHIARA, A. Corpos petulantes: desafios, esquivas, derivas. Revista Letras, v. 84, p. 59-75, 2011.

CHIARELLI, D. T. Apresentação. In: Catálogo da Exposição: Erótica - os sentidos na arte. Centro Cultural Banco do Brasil, 2005.

COELHO, L. (Org.). Intimidades. Rio de Janeiro: Editora Record, 2005.

COELHO, F. O. .Eu, Brasileiro, confesso minha culpa e meu pecado: Cultura Marginal e memória no Brasil dos anos 60 e 70. Rio de Janeiro: Civilização Brasileira, 2010.

Livro ou livro-me - os escritos babilônicos de Hélio Oiticica (19711978) Rio de Janeiro: EdUERJ, 2010.

CONNOR, S. Cultura Pós-Moderna. São Paulo: Edições Loyola, 2004.

COUTO, E. S. \& GOELLNER, S. V. (orgs). O triunfo do corpo - Polêmicas contemporâneas. Petrópolis: Vozes, 2012.

DELEUZE, G. Desejo e prazer. Arquivo em formato digital, s/d. Disponível em http://michelfoucault.weebly.com/textos.html. Traduzido de "Désir et plaisir". Magazine Littéraire. Paris, n. 325, Oct 1994, p. 57-65. 
. O que é um dispositivo? Arquivo em formato digital, s/d. Disponível em http://michelfoucault.weebly.com/textos.html. Tradução de Wanderson Flor do Nascimento de "Que és undispositivo?" In: Michel Foucault, filósofo. Barcelona: Gedisa, 1990.

. Mil platôs: capitalismo e esquizofrenia 1. São Paulo: Ed. 34, 2011.

Mil platôs: capitalismo e esquizofrenia 2. São Paulo: Ed. 34, 2011.

. A lógica da sensação. Rio de Janeiro: Zahar, 2007.

. Nietzsche e a filosofia. 2. ed. Porto: Rés, 2001.

O Anti-Édipo: Capitalismo e Esquizofrenia. São Paulo: Ed. 34, 2010.

DELEUZE, G. e GUATTARI, F. O que é Filosofia? São Paulo: Editora 34, 2000.

EAGLETON, T. A ideia da cultura. São Paulo: Editora Unesp, 2011.

EISLER, R. O prazer sagrado - Sexo, mito e política do corpo. Rio de Janeiro: Rocco, 1996.

FACCO, L. As heroínas saem do armário: literatura lésbica contemporânea. São Paulo: GLS, 2004.

FAVARETTO, C.F. A invenção de Hélio Oiticica. São Paulo: EDUSP, 1992.

FOUCAULT, M. Em defesa da sociedade: curso no Collège de France, (19751976). São Paulo: Martins Fontes, 1999.

Prefácio à transgressão. In: Estética: literatura e pintura, música e cinema. Coleção Ditos e escritos III. Manoel Barros da Motta (org.). Rio de Janeiro: Ed. Forense, 2001

História da Sexualidade I: A vontade de saber. Trad. Maria Thereza da Costa Albuquerque e J. A. Guilhon Albuquerque. Rio de Janeiro: Edições Graal, 1988.

- Microfísica do Poder. Org. e trad. Roberto Machado. Rio de Janeiro: Edições Graal, 1979.

. O corpo utópico, as heterotopias. São Paulo: n-1 Edições, 2013.

História da Loucura na Idade Clássica. São Paulo: Ed. Perspectiva, 1972.

A arqueologia do saber. Rio de Janeiro: Forense Universitária, 2005. 
FRIEDMAN, D.M. Uma mente própria. Rio de Janeiro: Objetiva, 2002.

GALANTIN, D.V.Considerações sobre "O Erotismo", de Georges Bataille:

Um pensador do paradoxo e da transgressão. Revista Cadernos de Clio, v. 1, p. 9-17, 2010

GARRAMUÑO, F. A experiência opaca: literatura e desencanto. Rio de Janeiro: EdUERJ, 2012.

GAY, P. Modernismo: o fascínio da heresia: de Baudelaire a Beckett e mais um pouco. São Paulo: Companhia das Letras, 2009.

GEERTZ, C. Nova luz sobre a antropologia. Rio de Janeiro. Jorge Zahar Editor: 2001 .

GIL. J. Metamorfoses do corpo. Lisboa: Relógio d'água, 1997.

A Imagem-Nua e as Pequenas Percepções - Estética e metafenomenologia. Lisboa: Relógio d'água, 2005.

GIUMBELLI, E. A sacralidade do desencanto: breves notas sobre dois conceitos célebres. In: II Congresso Internacional em Ciências da Religião, Goiânia, 2008 .

GLUSBERG, J. A arte da performance. São Paulo: perspectiva, 2011.

GOLDENBERG, M. (org.). Nu \& vestido: dez antropólogos revelam a cultura do corpo carioca. Rio de Janeiro: Record, 2002.

O corpo com capital. Rio de Janeiro: Estação das Letras, 2010.

GREINER, C. \& AMORIM, C. (orgs). Leituras do sexo. São Paulo: Annablume, 2006.

HALL, S. A identidade cultural na pós-modernidade. Rio de Janeiro: DP\&A, 2011.

. Quem precisa da identidade? In: SILVA, T. T. (org. e trad.). Identidade e diferença: a perspectiva dos estudos culturais. Petrópolis: Vozes, 2000. p. 103-133.

HAUSER, A. História social da literatura e da arte. São Paulo: Mestre Jou, 1982.

JAMESON. F. Pós-Modernidade e Sociedade de Consumo. Disponível em: http://novosestudos.uol.com.br/v1/files/uploads/contents/46/20080623_pos_modernidade.pdf

JEUDY, H.P. O corpo como objeto de arte. São Paulo: Estação Liberdade, 2002. 
KIFFER, A.O que é preciso para se refazer um corpo? Comunicação \& Política, v. 25, p. 203-210, 2007.

Sobre limites e corpos extremos. In: Olinto, H. K.\& SCHOLLHAMMER, K. E. (orgs.). Literatura e criatividade. Rio de Janeiro: 7Letras, 2012.

KLINGER, D.A escrita de si como performance. Revista Brasileira de Literatura Comparada, v. 12, p. 11-30, 2008.

.Paixão do arquivo. Matraga (Rio de Janeiro), v. 14, p. x, 2007.

LAPOUJADE, D. Deleuze, os movimentos aberrantes. São Paulo: n-1 Edições, 2015.

LOPES, A. H..Performance e história. O Percevejo, Rio de Janeiro, v. 12, p. 5$15,2003$.

MAMMI, L. Erudito/Popular. In: Adauto Novaes. (Org.). Cultura. Substantivo Plural. Rio de Janeiro: Editora 34, 1996, v., p. 185-192.

MATESCO, V. Corpo, imagem e representação. Rio de Janeiro: Zahar, 2009.

MERLEAU-PONTY, M. Fenomenologia da percepção. São Paulo: Martins Fontes, 1996.

MORAES, E. R. O Corpo impossível. São Paulo: Iluminuras, 2012.

Perversos, Amantes e Outros Trágicos. São Paulo: Iluminuras, 2013.

MORAES, E. R.\& LAPEIZ, S. O que é pornografia. São Paulo: Brasiliense, 1984.

NABAIS, C. P. Filosofia, Arte e Ciência: modos de pensar o acontecimento, IV Jornadas Ibéricas: Filosofia das Ciências, Lógica e Linguagem. Colóquio Internacional no âmbito do projecto. Lógica universal e Unidade da ciência/Universal logicsandUnityof Science (CFCUL/Universidade de Sevilha), Acções Integradas 2008-2010, Universidade deSevilha, 26 e 27 de fevereiro de 2009.

NANCY, J.L. Corpo, fora. Rio de Janeiro: 7Letras, 2015.

NIETZSCHE, F. W. A visão Dionisíaca do Mundo e outros textos de juventude. [edição em pdf] 1988.

O nascimento da tragédia, ou Helenismo e pessimismo. São Paulo:

Companhia das Letras, 1992.

NOVAES, A. (Org.). Muito além do espetáculo. São Paulo: Editora Senac, 2015

OLINTO, H. K. Pequenos ego-escritos intelectuais. Palavra, 10, 2003, p. 24-44. 
\& SCHOLLHAMMER, K. E. (orgs.). Cenário contemporâneos da escrita. Rio de Janeiro: 7Letras: PUC-Rio: FAPERJ: CNPQ, 2014.

F.;R. NASCIMENTO, C. T. Do. A construção social do conceito de Infância. Linhas (UDESC), v. 09, p. 04-18, 2008

ORELlANA, R. C. A ética da resistência. Revista Puc- SP, 2012. Ecopolítica: páginas 37-63

OSÓRIO, L. C. Entre o ver e o ler. In: SUSSEKIND, F; DIAS, T. A historiografia literária e as técnicas de escrita: Do manuscrito ao hipertexto. Rio de Janeiro: Edições Casa de Rui Barbosa: Vieira e Lent, 2004

PAGLIA, C. Personas Sexuais: arte e decadência de Nefertite a Emily Dickinson. São Paulo: Companhia das Letras, 1992

PARKER, R. G. Corpos, prazeres e paixões - A cultura sexual no Brasil contemporâneo. São Paulo: Editora Best Seller, 2001.

PASSOS, L. A era farmacopornográfiaca. 2012. Disponível em:

https://ensaiosdegenero.wordpress.com/2012/04/27/a-era-farmacopornografica/

PAZ, Octavio. Signos em rotação. Perspectiva: São Paulo, 2009.

PELBART, P. P. A vertigem por um fio. São Paulo: Iluminuras, 2000.

. VIDA CAPITAL - Ensaios de biopolítica. São Paulo: Iluminuras,

2003.

PIRES, E. Cidade Ocupada. Rio de Janeiro: Aeroplano, 2007.

PRECIADO, B. Manifesto contrassexual. São Paulo: n-1 edições, 2014.

. Multitudesqueer: Notas para una política de los "anormales", Revista Multitudes. $\mathrm{N}^{\mathrm{o}}$ 12. Paris, 2003.

QUILICI, C. S.AntoninArtaud e os Destinos dos Apetites. In: Christine Greiner; Claudia Amorim. (Org.). Leituras do Sexo. 1ed.São Paulo: Annablume, 2006, v., p. $67-75$

RAGO, L. M.A Subjetividade Feminina Entre O Prazer e A Norma. REVISTA BRASILEIRA DE HISTORIA, v. 3, n.28, 1995.

- Descobrindo historicamente o gênero. Cadernos Pagu (UNICAMP), Campinas, v. 11, p. 89-93, 1998.

.O corpo exótico, espetáculo da diferença. Labrys (Edição em Português. Online), v. 13, p. 7-21, 2008. 
RANCIÈRE, J. A partilha do sensível. São Paulo: Editora 34, 2005.

RABINOW, P\& ROSE, N. O conceito de biopoder hoje. POLÍTICA \& TRABALHO Revista de Ciências Sociais no. 24 abril de 2006 - p. 27-57

RIOS, C. As traças. São Paulo: Brasiliense, 2005.

Eu sou uma lésbica. Rio de Janeiro: Azougue Editorial, 2006.

Uma mulher diferente. Rio de Janeiro: Record, 1980.

RIVERA. T. O avesso do imaginário: Arte contemporânea. São Paulo: Cosac Naify, 2013.

ROLNIK, S.\& GUATTARI, F. Micropolítica: cartografia do desejo. 12. ed. Petrópolis: Vozes, 2014.

Cartografia Sentimental. Transformações contemporâneas do desejo. 6a. ed. Porto Alegre: Sulina, 2014

. Geopolítica da cafetinagem. Ide (São Paulo), v. 29, p. 123-129,

2006.

Guerra dos gêneros \& guerra aos gêneros. Ensaio escrito sob encomenda de TRANS. Arts. Cultures. Media (Nova York, Passim, inc.), para a abertura da seção «Genders War» nº 3 da revista, 1996.

. Cartografia ou de como pensar um corpo vibrátil. Disponível em: http://www.pucsp.br/nucleodesubjetividade/Textos/SUELY/pensarvibratil.pdf

ROSA, R. M. Sobre Corpo e Corporeidade, 2012. Disponível em: http://nuvic.com.br/2012/03/sobre-corpo-e-corporeidade/

ROTHIER, M. C. Entre os fantasmas do arquivo e o corpo da escrita. In: CHIARA, Ana Cristina; SANTOS, Marcelo; VASCONCELLOS, Eliane. (Org.). Corpos diversos -- imagens do corpo nas artes, na literatura e no arquivo. Rio de Janeiro: Editora da UERJ - EdUERJ, 2015, v., p. 179-194.

SAFATLE, V. P. disponível em: http://filosofia.fflch.usp.br/en/node/1219 - Acessado de março/novembro de 2014.

SANTIAGO, S. Aos sábados, pela manhã. Rio de Janeiro: Rocco, 2013. . "Caetano Veloso enquanto superastro". In: Uma Literatura nos trópicos. Rio de Janeiro: Rocco, 2000

SANTOS, R. J. Cassandra Rios e o surgimento da literatura gay e lésbica no Brasil. Disponível em: http://www.revistagenero.uff.br/index.php/revistagenero/article/view/233/154 
SCHØLLHAMMER, K. E. Além do visível: o olhar da literatura. Rio de Janeiro: 7 Letras, 2007.

SENNET, R. Sexualidade e solidão. Texto da internet, 1981

SERRES, M. Variações sobre o corpo. Rio de janeiro: Bertrand, 2004.

SIBILIA, P. A nudez auto exposta na rede: Deslocamentos da obscenidade e da beleza? Cadernos Pagu (UNICAMP. Impresso), v. 1, p. 171-198, 2015.

O que é obsceno na nudez? Entre a Virgem medieval e as silhuetas contemporâneas. Revista FAMECOS (Impresso), v. 21, p. 24-55, 2014.

SOUSA, R. L.Meta(na)morfoses Lésbicas em Cassandra Rios. Revista Estudos Feministas (UFSC. Impresso), v. 21, p. 129-141, 2013

TELES, G.M. Vanguarda europeia e modernismo brasileiro. Rio de Janeiro: José Olympio Editora, 2013.

TVARDOVSKAS, L. S.; RAGO, L. M. O corpo sensual em Márcia X. In: Cristina Stevens; Tânia Navarro Swain. (Org.). A construção dos corpos: perspectivas feministas. 1ed. Florianópolis: Editora Mulheres, 2008, v. 1, p. 183-205

Corpo e erotismo na produção visual de Márcia X. . In: III Encontro de História da Arte - História da Arte e instituições culturais: Perspectivas em Debate, 2007, Campinas. Anais do I Encontro Nacional de Estudos da Imagem, 2007. v. 1. p. 664-677.

UNO. K. A Gênese de um corpo desconhecido. São Paulo: n-1 Edições, 2012.

VELLOSO, M. P. \& OLIVEIRA, C. (orgs). Corpo: identidades, memórias e subjetividades. Rio de Janeiro: Maud X, 2009

VIGARELLO, G. História da beleza. Rio de Janeiro: Ediouro, 2006.

História do corpo. Rio de janeiro: Ediouro, 2008.

VILLAÇA, N. \& GÓES, F. Em nome do corpo. Rio de Janeiro: Rocco, 1998. . (Org.). Que corpo é esse? Rio de Janeiro: Mauad, 1999.

. A edição do corpo: tecnociência, artes e moda. São Paulo: Estação da Letras e Cores Editora Ltda., 2011.

X. M. X. Arte da performance: Arte contemporânea. Rio de janeiro: MAM, 2013.

ZUMTHOR, P. Performance, recepção, leitura. São Paulo: Cosac Naify, 2007 
Documentários, filmes e vídeos:

KECHICHE, A. Azul é a cor mais quente. França: IMOVISION, 2013.

A Vênus negra. França: IMOVISION, 2010.

KORICH, H. Cassandra Rios - A Safo de Perdizes. PROAC, 2013.

MORAES, E.R. A pornografia. Disponível em: https://www.youtube.com/watch?v=oqasXWtpxBk

PASOLINI, P.P. Quadrilogia da Vida e da Morte. Itália: DREAMLAND (DVDS), s/d.

RIEFENSTAHL, L. Olympia. Edição especial - documentário completo. Berlim: Sonopress Rimo Indústria, 1938.

Revistas:

Revista Galileu. Editora Globo. Novembro de 2015, edição 292.

Revista Item-4. Editores:BASBAUM, R. \& COIMBRA E. Novembro de 1996, Rio de Janeiro 